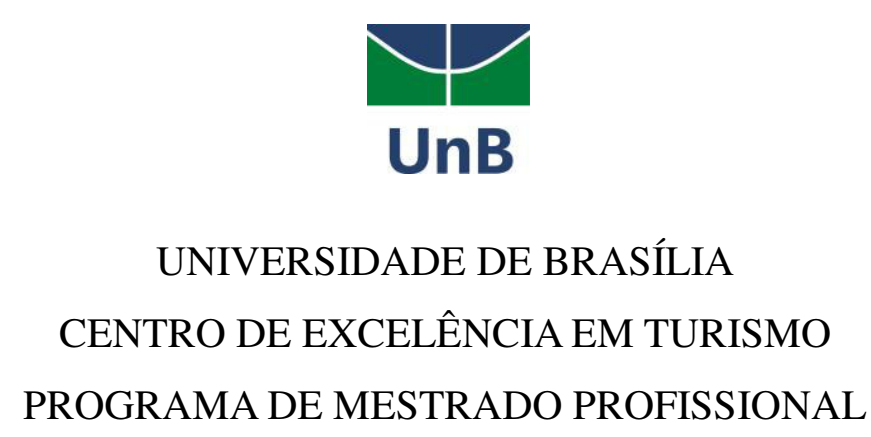

\title{
O ROCK BRASILIENSE DOS ANOS 80 NA CONSTRUÇÃO DO IMAGINÁRIO URBANO: PERSPECTIVA DE FOMENTAÇÃO DO TURISMO CULTURAL
}

Rogério Galeno do Nascimento Júnior

BRASÍLIA 


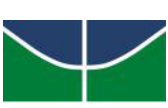

\section{UnB}

UNIVERSIDADE DE BRASÍLIA

CENTRO DE EXCELÊNCIA EM TURISMO

PROGRAMA DE MESTRADO PROFISSIONAL

\section{O ROCK BRASILIENSE DOS ANOS 80 NA CONSTRUÇÃO DO IMAGINÁRIO URBANO: PERSPECTIVA DE FOMENTAÇÃO DO TURISMO CULTURAL}

Rogério Galeno do Nascimento Júnior

Dissertação de Mestrado apresentada ao Programa de Mestrado Profissional em Turismo da Universidade de Brasília como parte dos requisitos para obtenção do título de Mestre em Turismo.

Orientação: Prof. Dr. Neio Lúcio de Oliveira Campos

BRASÍLIA 
Ficha catalográfica elaborada automaticamente, com os dados fornecidos pelo(a) autor(a)

GALENO, Rogério Galeno do Nascimento Júnior

O ROCK BRASILIENSE DOS ANOS 80 NA CONSTRUÇÃO DO IMAGINÁRIO URBANO: PERSPECTIVA DE FOMENTAÇÃO DO TURISMO CULTURAL / Rogério Galeno do Nascimento Júnior GALENO; orientador Neio Campos. -- Brasília, 2015.

$99 \mathrm{p}$.

Dissertação (Mestrado - Mestrado Profissional em Turismo) -- Universidade de Brasília, 2015.

1. Imaginário Urbano. 2. Rock. 3. Turismo Cultural. 4. Brasília. 5. Anos 80. I. Campos, Neio, orient. II. Título. 


\section{W \\ UnB \\ UNIVERSIDADE DE BRASÍLIA \\ CENTRO DE EXCELÊNCIA EM TURISMO \\ PROGRAMA DE MESTRADO PROFISSIONAL}

Dissertação de Mestrado submetida à Banca Examinadora designada pelo Colegiado do Programa de Pós-Graduação em Turismo da Universidade de Brasília - UnB, como parte dos requisitos para obtenção do título de Mestre em Turismo.

Rogério Galeno do Nascimento Júnior

Aprovado por:

Prof. Dr. Neio Lúcio de Oliveira Campos (orientador)

Pof $^{\mathrm{a}}$. Dr ${ }^{\mathrm{a}}$. Karina e Silva Dias

$\operatorname{Prof}^{\mathrm{a}} \mathrm{Dr}^{\mathrm{a}}$ Iara Brasileiro 
O homem colocou no mundo a cidade, qual imitação em escala gigantesca de si próprio. Ela é tão boa e tão má como o próprio homem. Mas ela the cria novas possibilidades e impele o bom para o sublime e o mau para o perverso. Quem quiser o sublime, terá sem dúvida de aceitar também o perverso. Quem quiser a liberdade deverá arcar também com os riscos da liberdade. Quem quiser a civilização, deve aprovar a cidade, a grande cidade. 
Esta dissertação é dedicada a Elenice Pacheco Carneiro. 


\section{AGRADECIMENTOS}

- Ao Prof. Dr. Neio Lúcio de Oliveira Campos pela orientação e fundamentais contribuições acadêmicas;

- Aos entrevistados Néio Lúcio Moraes Barreto, Paulo Mattos, Rodrigo Leitão e André Noblat pela colaboração e valiosos depoimentos;

- A Márcia Lyra Nascimento Egg pelo apoio na degravação da entrevista concedida por Néio Lúcio Moraes Barreto;

- Aos Professores do Mestrado Profissional em Turismo do Centro de Excelência em Turismo da Universidade de Brasília - CET UNB, pelas contribuições dadas dentro de suas respectivas áreas;

- A Fernanda Sant'anna pelas contribuições técnicas e motivacionais. 


\section{RESUMO}

O rock brasiliense dos anos 80 ficou conhecido como sendo o primeiro movimento musical expressivo da nova capital brasileira. Este destaque superou o âmbito da música e influênciou manifestações políticas, o vestuário da época, as maneiras de pensar de uma geração e, reflete, hoje, tal influência em obras cinematográficas e nas músicas que ainda são trilha sonora de muitas atividades que compreendem o estilo rock. Esse trabalho tem por objetivo, através da análise de textos, imagens e sons, investigar como o legado do rock brazilense pode ser reconhecido como potencialmente turístico. Para tanto, aliou-se teorias do turismo à cultura, noções de espaço e comunicação, no sentindo de se entender manifestações culturais em Brasília por um prisma turístico no desvelamento do imáginario criado pelo rock brasiliense dos anos 80 .

Palavras chave: Imaginário Urbano. Rock. Brasília. Anos 80. Turismo Cultural. 


\begin{abstract}
The Brasília '80s rock became known as the first significant musical movement of the new Brazilian capital. This highlighted exceeded the scope of music and influenced political demonstrations, the clothing of the time, the ways of thinking of a generation and reflects today such influence in cinematographic works and in songs that are still the soundtrack of many activities that comprise the style rock. This work aims, through the analysis of texts, images and sounds investigate how this legacy rock can be recognized tourist potential. To this end, allied theories of tourism to culture, space and communication concepts in the feeling of understanding cultural events in Brasília by a tour prism in unveiling the imaginary created by Brasília ' 80 s rock.
\end{abstract}

Keywords: Imaginary Urban. Rock. Brasília. 80’s. Cultural Tourism. 


\section{LISTA DE ILUSTRAÇÕES}

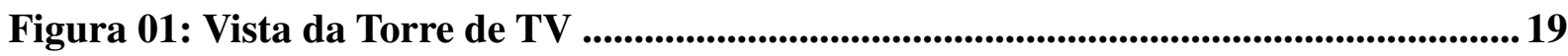

Figura 02: Vista da Torre de TV Digital ..................................................................................20

Figura 03: Concerto Cabeças na 311 Sul ..............................................................................43

Figura 04: Concerto Cabeças ............................................................................................................ 49

Figura 05: Pichação “Aborto Elétrico" .........................................................................55

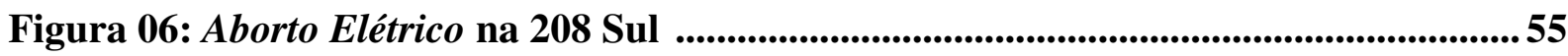

Figura 07: Gilberto Salomão em 1984 ....................................................................................................56

Figura 08: Rock na Quadra ...................................................................................................................5 59

Figura 09: Lançamento do Movimento Brasília Capital do Rock (2012) ........................... 63 


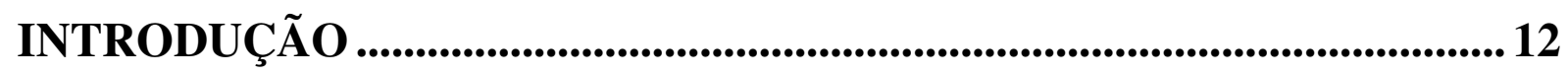

1. ARTES DE FAZER, NOÇÃO DE ESPAÇO \& PRÁTICAS

COTIDIANAS ......................................................................................... 15

2. IMAGINÁRIO, CULTURA \& TURISMO_............................................. 27

3. O ESPAÇO PRATICADO \& O ROCK BSB 80......................................35

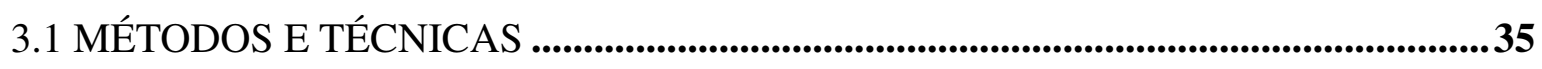

3.2 APRESENTAÇÃO E DISCUSS ÃO DOS DADOS ............................................................39

3.3 O ROCK NO MUNDO, NO BRASIL, EM BRASÍLIA ....................................................44

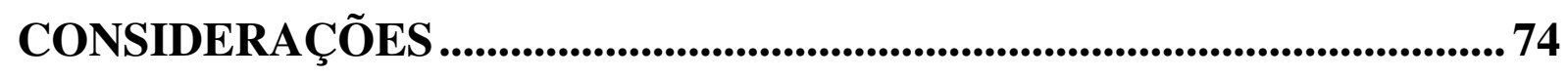

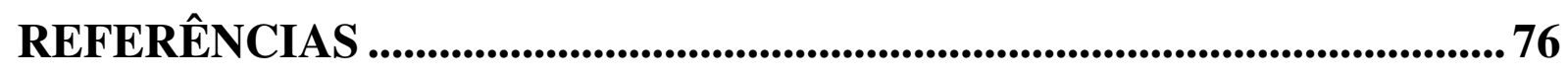

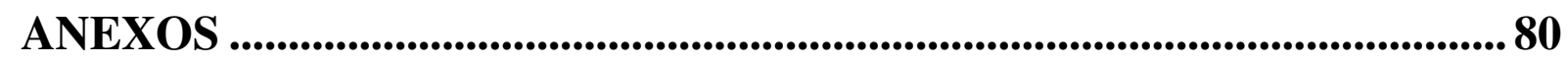

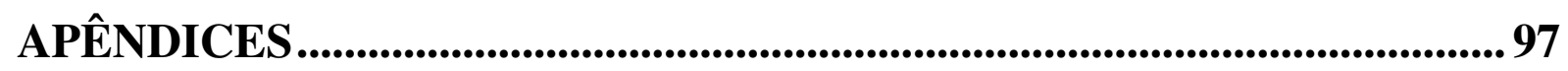




\section{INTRODUÇÃO}

$\mathrm{Na}$ década de 80, período ao qual se refere esta pesquisa, surgiu em Brasília uma quantidade considerável de músicos e bandas que compuseram letras que criticavam o poder público, a corrupção e restrições remanescentes da ditadura militar: o rock brasiliense dos anos 80 (rock BSB 80). Apesar desses artistas, por vezes, se oporem a questões menos específicas, de âmbito nacional, Brasília era a referência imediata.

O instigante nesta relação entre música, protesto e imaginário urbano é que esta fase artística-musical de Brasília foi notável. Notável a ponto de fazer surgir correntes que consideram e propagam Brasília como sendo "a capital do rock". De acordo com Bauer (2002) “o que uma pessoa lê, olha ou escuta, coloca esta pessoa em determinada categoria, e pode indicar o que a pessoa pode fazer no futuro. Categorizar o presente, às vezes, predizer futuras trajetórias é o objetivo de toda pesquisa social" (BAUER, GASKELL e ALLUM, 2002, p. 22). Propõe-se, através desta análise e dos métodos de que ela se vale, abordar o rock BSB 80 como um agente modificador da imagem da cidade e mesmo como potencial turístico-cultural, além de contribuir para os estudos culturais refletindo sobre tal período, considerado auge do rock em Brasília.

Qual seria o recorte apropriado para tratar hoje o legado cultural de um estilo musical de uma década passada? Souza (2008) alerta:

Refletir sobre a produção da cultura e da subjetividade exige um olhar crítico sobre os múltiplos atravessamentos dos fluxos de imagens que invadem os espaços públicos e privados dos sujeitos contemporâneos, especialmente daqueles que habitam as grandes metrópoles. As janelas virtuais se abrem para uma infinidade de espaços interativos onde os sujeitos experimentam o espaço e o tempo em uma ampla variedade de formas de linguagem. Neste contexto, indagar-se sobre os modos como o uso das tecnologias interfere no campo das relações humanas, estabelecendo novos padrões de interatividade e de linguagem pautadas pela experiência dos sujeitos com os meios de comunicação de massa, é um dos grandes desafios para a pesquisa em ciências humanas de um modo geral (JOBIM E SOUZA, 2008, p. 265). 
Compreende-se que a cidade, o tempo, o espaço, o artista e até o tempo musical (ritmo, andamento, compassos) subjetivamente influenciam e são influenciados na criação, que passa pela imaginação. Para não cair na mera conceituação desses termos ou numa retrospectiva do que foi o rock BSB 80 e reduzi-lo a uma tipologia de turismo pensou-se: Por que não imaginá-lo? Sobre imaginário e turismo a professora Susana Gastal reflete:

\footnotetext{
Viagens e imaginários sempre andaram juntos, daí sua importância para o turismo. Enfrentar o desconhecido, ou simplesmente adentrar o novo, causa uma certa instabilidade nas pessoas. Assim, o espaço desconhecido será ocupado pelos sentimentos das pessoas em relação a ele, sentimentos que serão materializados de diferentes maneiras em diferentes momentos históricos (GASTAL, 2005, p. 57).
}

Pela noção de imaginário, no imaginário ou através de imaginários urbanos construídos pelo rock BSB 80 está o montante não seccionado, a fonte de informações sobre essa década. Imaginá-la é enxergá-la viva, a sua vida de agora e de antes. Esta conectividade entre momentos dá a sensação de uma existência ininterrupta como o dia a dia, que nesta abordagem não é necessariamente o ontem-hoje-amanhã e sim uma visão cotidiana dos modos de fazer, das práticas urbanas. Daí coube se valer de preceitos de Michel de Certeau, que abrigou em suas reflexões muito da temática da qual se ocupa esta investigação.

O objeto da presente pesquisa é indissociável de seu tempo, de seu elemento e de seu lugar. Por isso, pode-se dizer que o rock BSB 80, sem levar em conta nesta afirmação seus aspectos influenciáveis e influenciadores, tem fronteiras bem definidas. Não fronteiras físicas num sentido fixo, determinante. Está mais no campo ideal. Mais à frente, será entendido que aqui, o rock BSB 80 é visto como uma prática criadora, inventora, fomentadora de espaço e de acordo com Certeau (1994), "não existe espacialidade que não organize a determinação de fronteiras" (CERTEAU, 1994, p. 209). Trata-se da referência ao estilo musical, alusão à cidade àquela década, àquela maneira. Aí está a multiforme do objeto: a vida em Brasília nos anos 80, que imbrica a década de 80 em Brasília na história do rock mais as abordagens: rock de Brasília, rock anos 80 e, finalmente, a junção: rock de Brasília da década de 80 com vistas ao turismo cultural de hoje. Tentou-se apreender aqui o rock BSB 80 no turismo ou identificar de que forma o turismo pode se valer espacialmente de manifestações músico-culturais em Brasília. 
Feitas tais considerações pergunta-se: $O$ imaginário urbano percebido a partir do rock BSB 80 pode acrescentar capital cultural no sentido de estimular o desenvolvimento do turismo cultural em Brasília?

Muito da estratégia para se entender o rock BSB 80 no turismo é captar o “movimento local”. É entender como se deram as manifestações dos sujeitos, sobretudo no que tange a apropriação dos espaços destinados e/ou adequados ao rock. É saber sobre como seus adeptos reagiam, quais eram suas táticas para se posicionarem, se retraírem e se mostrarem em Brasília.

A cidade planejada, além de características físico-estruturais próprias, possui particularidades nos seus modos de fazer. Em Brasília, tais propriedades nasceram com a cidade e persistem. Por exemplo, como possui apenas 55 anos não se têm estabelecidas, em Brasília, longas linhagens familiares. Isto sucumbe ao fato de que muitos pais dos filhos de Brasília (salvo os filhos mais jovens) não são brasilienses. É menos provável, ainda, que os avós e bisavós sejam. Este não pertencimento ocorre também com os bens culturais, aqui, especificamente com a música. Não que a música nas cidades mais antigas lhes seja própria; é que em Brasília não se começou e se caminhou por um tradicionalismo interior, se mergulhou nas influências. É quase uma colonização, uma colonização sem resistência, se bem que o surgimento da nova cidade, a chegada de seus pioneiros habitantes foi quase que contemporânea ao nascimento do rock brasileiro, o que leva a crer que a autenticidade do rock BSB 80 pode estar nisto.

Quando se transpõe tais pensamentos ao âmbito sociocultural, ao público de rock, fazendo alusão aos conteúdos das letras, começa-se a entender porque, do underground aos espaços mais comuns e usuais, emerge um sentimento nostálgico que se materializa não só num estilo musical persistente, mas também nas manifestações, no gosto, nos gestos das pessoas. Esta atmosfera, de um ciclo retroalimentado pelo passado, traz em si curiosidades a serem investigadas. Dúvidas ligadas ao por que Brasília sugere potenciais turístico-culturais tão concretos e ao mesmo tempo duvidosos.

Em suma, objetiva-se analisar o imaginário urbano construído pelo rock BSB 80 numa perspectiva de fomentação do turismo cultural em Brasília. 


\section{ARTES DE FAZER, NOÇÃO DE ESPAÇO \& PRÁTICAS COTIDIANAS}

Michel de Certeau (1994) discute as práticas cotidianas, as artes de fazer. Para este autor, o homem em seu mundo cotidiano, em seu dia a dia vive dividido entre o que seria cientificamente estabelecido e o que não. No entanto, Certeau não sucumbia toda forma de conhecimento à ciência, nem mesmo concordava com o seccionamento de disciplinas. Certeau relativizava a noção de verdade e suspeitava da objetividade das instituições do saber.

Certeau prezava por entender o momento presente, o que estava acontecendo; não se ocupava em apresentar diagnósticos, em propor soluções. Para ele, os feitos primitivos anteriores à tendência de cientifização das coisas saltam um espaço de tempo e são rendidos posteriormente à cientifização. Aquilo - que é manufaturado, pensado, em que há técnica, conhecimento obtido - que não é cientifizado é arte, "arte de fazer". (CERTEAU, 1994, p. 137).

Considera-se que o comportamento dos adeptos, dos influenciados e influenciáveis do rock BSB 80 é artístico, é praticável, transpõe a teoria. Fazer uso da "Invenção do Cotidiano" de Certeau é situar o rock BSB 80 no limite entre a prática e o discurso, já que, para ele, "as práticas registram uma 'verdade' do fazer (interpretação) e o discurso decodifica as 'mentiras' do dizer (descrição)” (CERTEAU, 1994, p. 39 grifo do autor).

Por que o rock BSB 80 passa pela construção do imaginário? É coerente recriá-lo apenas porque o objeto está no passado? A intenção está em olhar/imaginar o rock BSB 80 como fenômeno estranho que se legitima. Está em entender como se dá seu processo de legitimação. Entender por que, em relação a ele, há a sensação de que não vivemos no lugar em que o passado passou, de que não está genuinamente vivo nem esquecido: "Tem ares de imaginário", de acordo com Certeau (CERTEAU, 1994, p. 86).

O autor abre caminho para esta reflexão quando evidencia:

Por razões econômicas, nacionais e culturais voltamos ao passado que muitas vezes envelheceu menos que o novo. Renova-se mais do que se inova, reabilita-se mais que do que se constrói, protege-se mais do que se cria” (CERTEAU, 1994, p. 191). 
A correlação do presente com o passado não pode esbarrar no erro de se olhar para traz e considerar apenas a década de 80. Para Certeau (1994), a compartimentalização dos tempos e dos lugares é uma lógica disjuntiva da especialização pelo e para o trabalho. A dita década de 80 foi influenciada por outros tempos e construída em seu dia a dia por razões indicadas acima por Certeau. Razões estas que se desdobram no espaço, que nesta análise ocupa-se do recorte Brasília-DF.

Para tratar do meio urbano, sustenta-se, em conformidade com Certeau, que o patrimônio de uma cidade não é concebido a partir de objetos por ela criados, e sim, por suas “capacidades criadoras", por seus "estilos inventivos"; seu patrimônio são as "artes de fazer". Os gestos remanescentes de uma era cotidiana da vida urbana, novas experiências, os links entre os lugares e as práticas fazem da cidade "uma imensa memória em que prolifera a poética" (CERTEAU, 2003, p.199).

Seria, entretanto, muito amplo pensar as práticas cotidianas, apreender o dinamismo das ações dos seres no tempo e nos lugares. Os sujeitos desta reflexão poderiam ser quaisquer uns quando e em qualquer lugar. As práticas cotidianas multiplicam-se num sem número de combinações. No entanto, as maneiras de fazer rock BSB 80, dos operadores (atores/músicos/adeptos) correspondem procedimentos finitos. A invenção não é ilimitada, “supõe o conhecimento e a aplicação de códigos" (CERTEAU, 1994, p. 83). Ou seja, é pressuposta uma não autonomia do campo de ação. Certeau fez analogia às improvisações em instrumentos musicais que, para ele, implica uma lógica dos jogos de ações relativos a tipos de circunstâncias (CERTEAU, 1994, p. 83, grifo do autor). Na improvisação o músico dispõe de um campo harmônico limitado. Este campo pode estar contido no braço de uma guitarra ou no teclado de um piano. A improvisação se dá na combinação de notas dentro deste campo. Um leigo não poderia executar uma boa improvisação, pois não conhece o campo. O campo pode ser complexo, mas é finito. Esta lógica é articulada na ocasião. É situacional. Diferente de quando uma partitura é seguida, de quando uma métrica é estabelecida. Certeau assinalou que "toda sociedade mostra sempre, em algum lugar, as formalidades a que suas práticas obedecem" (CERTEAU, 1994, p. 83). Aqui, partilha-se das preocupações de Certeau quanto o quê os consumidores fabricam com as imagens e os sons; o quê os praticantes do espaço urbano "absorvem" e pelo quê consumidores de histórias recebem e pagam. Não se quer através de um levantamento dos bens culturais - como criticou Certeau - identificar padrões 
estatísticos, mapear pontos de convergência ou constatar os funcionamentos econômicos de sua difusão, mas entender um pouco sobre como os sujeitos desta pesquisa se apropriavam dos espaços de Brasília. Em outras palavras, esta é uma abordagem qualitativa que não pretende levantar todas as bandas, discos, público e o quanto isso gerou em vendagem, em partidas e chegadas.

Ainda sobre o consumo dos bens culturais, há situações em que o consumidor é afastado do produto, não marca nele sua atividade, é excluído da manifestação, não participa, apenas recepta o conteúdo - caso de alguns programas televisivos. O consumo é "quase invisível" ou torna quase tudo invisível, não é dotado de propriedade. Se no campo da ação a invenção é limitada, no do consumo ela é praticamente nula. A produção, a oferta é pronta e adiantadamente sugere-se que a opinião sobre o conteúdo também o será. Certeau lançou mão da colonização espanhola para exemplificar inversões discretas provocadas pelo consumo: os indígenas faziam uso das obrigações, das leis impostas para um interesse que não os dos colonizadores. Faziam com elas outras coisas. Nas palavras de Certeau:

[...] subvertiam-nas a partir de dentro - não rejeitando-as ou transformando-as (isto acontecia também), mas por cem maneiras de empregá-las a serviço de regras, costumes ou convicções estranhas à colonização da qual não podiam fugir. Eles metaforizavam a ordem dominante: faziam-na funcionar em outro registro. Permaneciam outros, no interior do sistema que assimilavam e que os assimilava exteriormente. Modificavam-no sem deixá-lo. Procedimentos de consumo conservavam a sua diferença no próprio espaço organizado pelo ocupante (CERTEAU, 1994, p. 94).

Tomando ciência deste tipo de inversão, do consumo de bens culturais, do uso que os meios "populares" fazem das culturas difundidas pelas "elites" produtoras (de linguagem, de som) questiona-se: em que momento letras que denigrem a cidade adquirem um novo sentido ao se ressignificarem num movimento cultural?

Certeau trilha seu caminho no sentido de congruência entre teoria e prática aproximando a arte de dizer à arte de fazer e de pensar. Supõe que uma "teoria do relato é indissociável de uma teoria das práticas” (CERTEAU, 1994, p. 153). Uma narrativização das práticas seria então uma "maneira de dizer" textual, com seus devidos "procedimentos" (termo proposto por Foucault) e suas "táticas" (termo proposto por Bordieu). 
Inserindo neste raciocínio elementos do rock BSB 80, depara-se com o impasse de não se poder definir onde a teoria termina e onde começa a prática. Primeiramente há de se abandonar o preceito de que a teoria antecede a prática, até mesmo porque Certeau propõe que há prática no teorizar, no inventar. A prática e a teoria se correlacionam e se produzem por vezes num campo verbal e noutras vezes num campo gestual. Pode-se dizer que há trocas entre o fazer e o dizer, entre o conto e a manifestação, entre o canto e o gesto.

Analisando desta forma, neste nível de aprofundamento, torna-se inviável e até difícil desassociar, por exemplo, letra e melodia ou partitura/cifra e execução/cantar/tocar. Um está no outro e o outro no um. Comenta-se a seguir um pouco do processo de composição de uma música. Antes, cabe citar um pensamento de Perrone (1988) sobre letra e melodia, ressaltando que o autor refere-se à letra como "texto" e à melodia (arranjo) como "música":

\begin{abstract}
Uma letra pode ser um belo poema mesmo tendo sido destinada a ser cantada. Mas é, em primeiro lugar um texto integrado a uma composição musical, e os julgamentos básicos devem ser calcados na audição para incluir a dimensão sonora no âmbito de análise. Mas, se independente da música, o texto de uma canção é literalmente rico, não há nenhuma razão para não se considerar seus méritos literários. A leitura da letra de uma canção pode provocar impressões diferentes das que provoca sua audição, mas tal leitura é válida se claramente definida como uma leitura [...] (PERRONE, 1988, p. 14).
\end{abstract}

A letra é algo pensado e pensar, neste caso, é fazer. Argumenta-se que esse momento inventivo é proveniente do quanto de palavras, experiências e capacidade de combinação teve o compositor. Este é o "letrar" da música, o compor de conteúdo. Isto vale também para a composição da melodia, mas com os elementos notas, experiências e capacidade de combinação. Na criação de uma música, a "apropriação do outro" na relação letra-melodia é ainda mais solúvel. Há pelo menos três modos factíveis: 1) primeiro pode nascer a melodia e nela ser inserida a letra; 2) a letra pode ser colocada numa melodia já feita; 3) melodia e letra podem ser criadas juntas, num único processo. Assim se dá, basicamente, a composição da letra e da melodia. Já a execução do canto e do tocar envolve técnicas vocais e instrumentais. O ponto a que se quer chegar através desta explanação é que há muita prática na dita etapa teórica. O produto final, a reprodução da música em si passou por muitos fazeres e no final, o que restou do rock BSB 80 é discurso, som e gesto. É letra, som e manifestação (imagem/estética). Por isso, não se trata apenas de um resgate. Sobre tal procedimento Certeau pergunta: seria um retorno à "descrição" da época clássica? Não. O que se busca não 
é um relato do que "foi" uma realidade passada. Certeau se refere a um "espaço de ficção" que a história narrada cria. A história narrada não descreve um "golpe", ela o faz (CERTEAU, 1994, p.153, grifo do autor).

Extensos horizontes estão na mente dos moradores de Brasília e dos que a visitam. Como a terra é pouco acidentada, a vista é plana em muitos pontos do Planalto Central. Esta horizontalização é também propiciada pela não existência de muitos prédios altos. Uma vista ampla da cidade pode ser captada de cima nos mirantes da Torre de TV e da Torre de TV Digital. Estes são dois olhares panorâmicos de Brasília: a vista de cima e a plana.

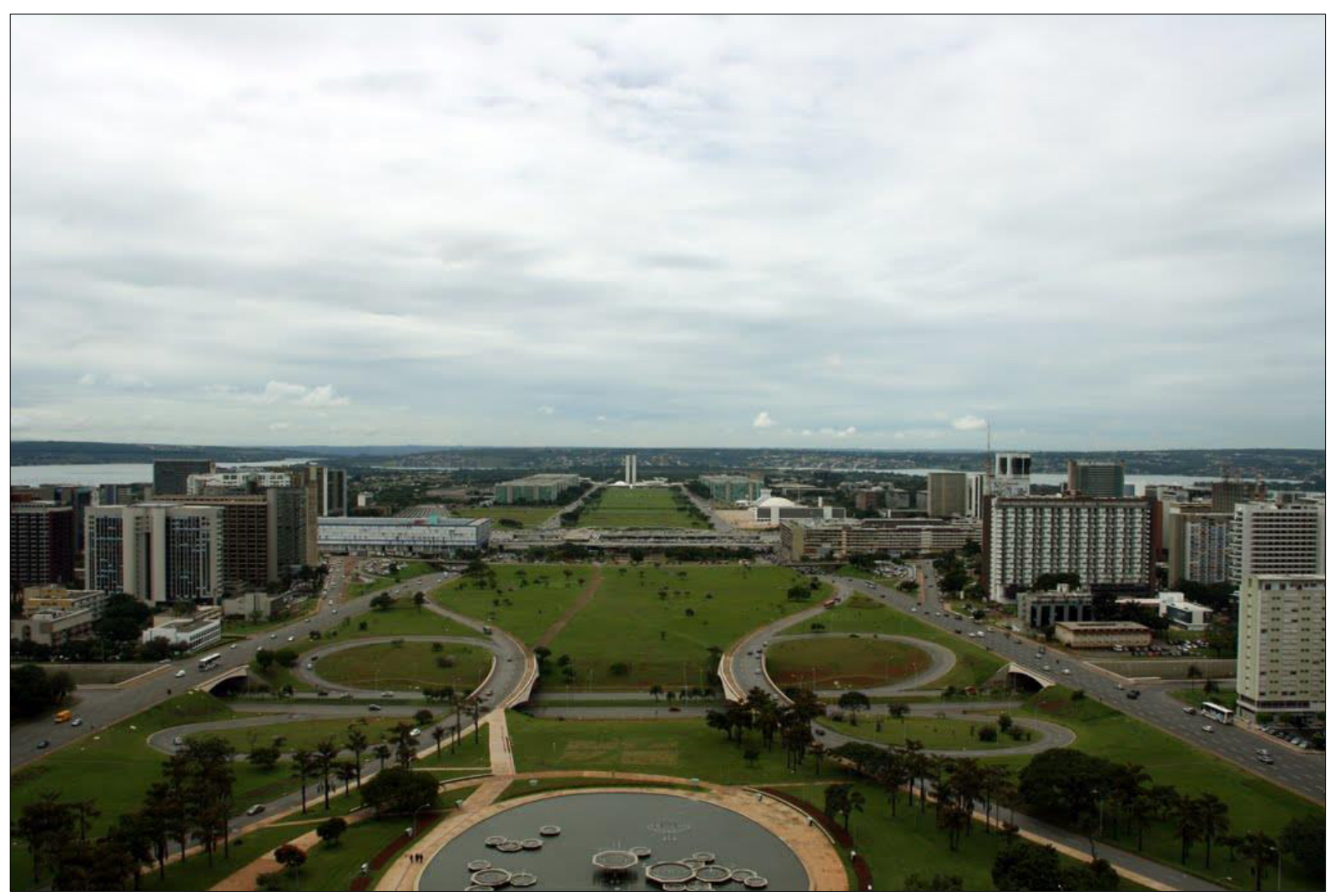

Figura 01: Vista da Torre de TV

Foto: Imagem extraída do Google Earth @ 2015 


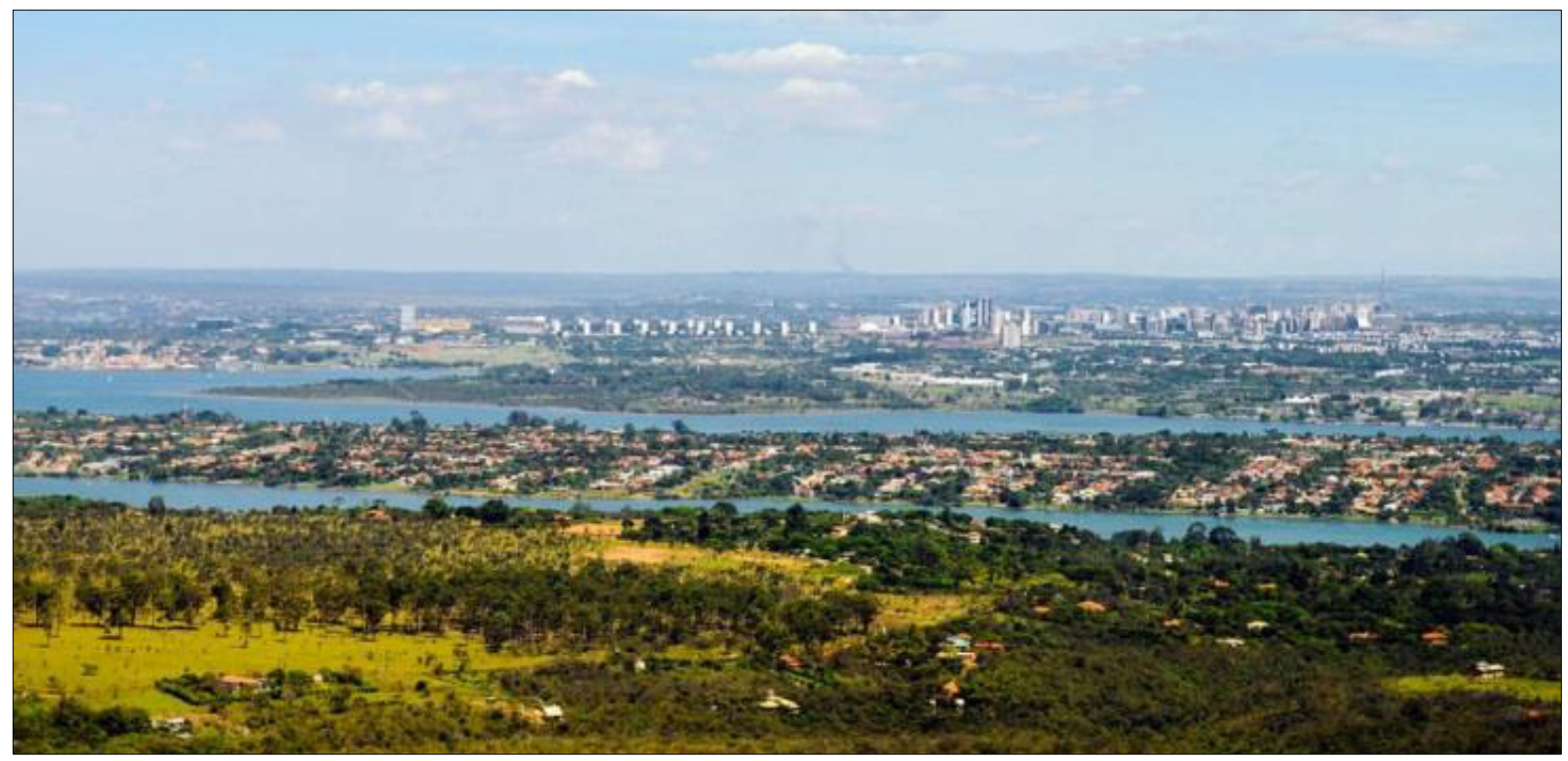

Figura 02: Vista da Torre de TV Digital

Foto: Monique Renne

Na cidade panorâmica, congelada, o cotidiano foge aos olhos. O olhar distante, de cartão postal, a totalização imaginária coloca o ser pensante na lógica da cidade planejada, pensada, funcional. Aí se é estrangeiro, consegue-se avistar a cidade concebida por quem nunca a viu. Agora embaixo, em frente, junto aos pedestres, aos usuários, está a outra cidade. No nivelamento da altura dos olhos se faz enxergar. Aqui estão os caminhantes, os falantes e ouvintes: os praticantes da cidade. Esta ideia pode ser mais bem explicada através da noção topoceptiva. De acordo com Kohlsdorf (1997), a topocepção:

[...] implica orientação e identificação das pessoas nos lugares e participa da formação de nossas estruturas cognitivas básicas; o desempenho topoceptivo de logradouros, bairros e cidades refere-se a suas possibilidades de informar aos que os frequentam sobre sua localização em certo recinto em relação a outros (KOHLSDORF, 1997, p. 587).

Para Certeau, a memória não é localizável. Nos gestos feitos, nas palavradas proferidas, no presente mora um passado. O que permanece é o lugar. Se há ressonância de um passado, o lugar diz qual é ou mesmo pode ser o fio condutor das maneiras de fazer no tempo? Certeau considera que "os lugares vividos são como presenças de ausências" (CERTEAU, 1994, p. 189). O aqui resiste. Pode-se pisar nele: na esplanada; no parque; na quadra; na UnB. 
De acordo com Certeau, as ações narrativas revelam formas elementares das práticas organizadoras de espaço. Os "relatos efetuam um trabalho que incessantemente transforma lugares em espaços ou espaços em lugares” (CERTEAU, 1994, p. 203). Resumidamente, um lugar é a ordem sob a qual são distribuídas as coisas; sua disposição fixa, rígida, estável. O espaço é a mobilidade dessas coisas, é a ação, "é um lugar praticado". O autor relativiza: "o espaço estaria para o lugar como a palavra quando falada" (CERTEAU, 1994, p. 202). Logo, o pedestre faz da rua um espaço. Nesta lógica, como se poderia relacionar a apropriação do espaço ou do sentido prático do lugar com/pela música? Aspectos melódicos são relevantes, mas são carregados de influências externas que transpõem em muito a delimitação do tema em questão. Desde a produção à recepção, a concentração pode ser voltada para a narrativa. As letras das músicas do rock BSB 80 são impregnadas de realidade social. Muitas captaram o sentimento das relações familiares, trabalhistas, artísticas e as traduziram em som. Alguns temas abordados nas letras variam de forma geral entre diversão, amores, violência, consumo de drogas, críticas ao governo. Há outros, que numa análise mais detalhada, podem revelar aspectos da paisagem urbana ou permitir, por exemplo, captar uma monotonia transformada em aversão ao governo militar incitada por jovens influenciados pelo punk rock que fizeram da revolução a sua referência.

Fala-se que Brasília não tem uma cultura própria, um sotaque próprio, uma culinária própria. No entanto, o espaço físico, os traços urbanos de Brasília são inegavelmente particulares e nesse espaço foi consolidado, na década de 80, o seu rock. Também no rock, a originalidade não se confunde. Os cidadãos de Brasília e do Brasil afora reconhecem a música dessa época como sendo o som de Brasília. Nasceu e se desenvolveu um imaginário e desta construção se deu um novo modo de se conceber e reproduzir a cidade.

Por ser uma cidade nova, Brasília caminha ainda para possuir um jeito próprio de produzir as coisas. Na verdade possuir 55 anos hoje - 20 em 1980 - é apenas um fator dentre outros que justificam esta última afirmação. Ser uma cidade planejada, ter sido construída por imigrantes de outras regiões do país e receber influência das culturas dos estados de Minas Gerais e Goiás, por exemplo, são pistas que conduzem a reflexão sobre o jeito de se fazer de Brasília. 
Nesse momento, o pensamento avança no sentido de se compreender o rock BSB 80 como uma prática urbana para a apreensão do imaginário urbano sob a perspectiva dessa prática. O próximo passo dessa empreitada é aproximar o objeto desta análise às percepções de Maria Elaine Kohlsdorf, em sua obra “A Apreensão da Forma da Cidade”. Percebeu-se que a abordagem de Kohlsdorf, a "apreensão" do espaço urbano, entrou oportunamente aqui quando se entendeu, em conformidade com a autora, que o espaço urbano, assim como a prática social nele contida, é sensivelmente captável; que apreensão indica tomada, receio e cisma, e apreender significa tomar, entender e compreender, que se adequa aos objetivos deste trabalho quando se propôs investigar a realidade social reagindo às manifestações de um estilo artístico-musical.

O plano de Lúcio Costa e os monumentos de Oscar Niemeyer criam na mente das pessoas uma rápida associação que referencia o lugar à sua funcionalidade. Entretanto, as imagens dos ministérios, dos poderes, do plano piloto assumem uma vertente simbólica que transpõe sua funcionalidade original.

Kohlsdorf (1996) aponta que a apreensão da forma da cidade se dá através de um processo de internalização da luminosidade (estímulo sensorial), que é na reprodução de símbolos que o existir urbano apresenta sinais. Na reflexão sobre como resgatar o viver em Brasília nos anos 80 e captar o sentimento das pessoas hoje em relação àquele tempo, percebeu-se que focar esta análise apenas nas músicas e suas letras sucumbiria uma subjetividade que não expressaria ao fim um conhecimento qualitativo, de cunho social que transpusesse prováveis interpretações pessoais, juízo de valores e reprodução do senso comum. Isso porque interpretar letras e melodias, por mais que haja técnicas para isto, pode ser considerado tão artístico e subjetivo quanto compô-las.

Há de se considerar, como será visto mais à frente, que a inserção de fotografias de Brasília, trechos de reportagens e depoimentos na discussão é fruto próprio desta construção teórica. Pode-se encontrar em filmes, longas-metragens, curtas-metragens e videoclipes, por exemplo, uma série de cenas do cotidiano, da apropriação do espaço. Há, nessas cenas, uma mescla entre imagens reais filmadas da cidade numa determinada época e montagens mais contemporâneas que recriam uma determinada data do passado. Esse espaço-tempo conota uma relação topológica. O conceito de relação topológica tende para a localização do sujeito 
no espaço. No entanto, na resposta do ser à mudança na disposição de estruturas físicas tem-se um espaço topológico. Isso ocorre, por exemplo, quando se percebe visualmente, através de um vídeo, as mudanças ocorridas na cidade. Nas palavras de Kohlsdorf, a construção topológica do espaço:

[...] é sequenciada por sua definição perspectiva, produzida exclusivamente pelo tipo de imagem colhida pela retina humana. A forma plana e as características cônicas, captadas pelo aparelho visual das pessoas, permitem uma organização do espaço contido em seu campo visual por meio dos atributos de cena perspectiva: figuras deformadas, tamanhos inexatos, ocultação dos objetos uns pelos outros, etc. (KOHLSDORF, 1996, p. 60).

Sendo relativo o posicionamento do ser no espaço topológico, há de se considerar que as perspectivas introduzidas nas imagens que mostram a história de Brasília influenciam dois níveis de público: os que viveram os anos 80 na cidade e os que não a viveram. Dentre os primeiros podem-se considerar pessoas que presenciaram o nascer e o desenvolver de bandas dos anos 80. Trata-se de sujeitos que viram e participaram da cidade nos anos 80 e que possuem condições de associar realidade e adaptação ou distinguir fato e ficção. O segundo público são os pós oitenta. São os que conciliam a atualidade com as imagens e os relatos dos tempos passados.

Voltando ao conceito de espaço topológico, acrescenta-se que esta noção se dá no desenvolvimento cognitivo da criança para a fase adulta. Mesmo no homem já maduro, portador da noção de espaço, a inteligência se desenvolve de forma processual, tanto quanto ocorre com suas estruturas cognitivas, a apreensão do ambiente passa pelo desenvolvimento das percepções, das sensações, carrega consigo noções primárias de situação espacial.

Além da relação topológica, Kohlsdorf traz também a relação perspectiva, que se refere à "noção de organização geométrica da cena contida no campo visual do observador" (KOHLSDORF, 1996, p. 78). Ambas as noções exprimem descrições dos lugares envolvendo o observador e a disposição das imagens a sua volta num jogo de proximidades, perspectivas e outras tantas possíveis disposições. Os efeitos topológicos e perspectivos são duas entre muitas decodificações possíveis que foram citadas com o objetivo de se entender um pouco sobre o processo de percepção dos lugares. 
Kohlsdorf aborda a Técnica de Análise Sequencial. Discorrer conceitualmente sobre esta técnica muito interessa ao desenrolar teórico e ao aporte metodológico deste estudo, já que o termo "sequência" foi cunhado da música - relativo à repetição de sons - e no aspecto urbanístico é empregado à sucessão de imagens/cenas. Sobre a técnica Kohlsdorf faz a seguinte explanação:

Os elementos e as relações características da percepção do espaço reúnem-se na técnica de análise sequencial, que procura representar a passagem progressiva do visto para o percebido, na sucessão de registros selecionados da composição morfológica de determinado lugar. A técnica investe na reprodução do movimento do mecanismo perceptivo e na transformação de manifestações sensíveis do espaço em noções de sua estrutura percebida. Em seus procedimentos dá-se também, porém uma série de reduções admitidas em nome de ganhos operacionais. A mais evidente é o fato de representar-se um nível de aprendizado que é exclusivamente de ação, passando-se a tratá-lo como os níveis evocativos (KOHLSDORF, 1996, p. 78).

Continuando a reflexão sobre como as pessoas percebem o meio urbano, como captam, internalizam e reproduzem as imagens e os sons do ambiente, será feita uma breve tentativa de se adequar ou correlacionar o objeto deste estudo à Técnica de Análise Sequencial. Tal empreitada não consiste em aplicar a técnica como método, até mesmo porque ela envolve aspectos quantitativos, codificações simbólicas e elaboração de pautas sequenciais, o que não condiz com a abordagem e com os desígnios deste trabalho.

Já foi mencionado que sequência é um termo originado de técnicas musicais, o que denota que no conteúdo das músicas, das trilhas há uma sequência. Entretanto, a sequência não indica apenas que há linearidade, que há um andamento musical. A sequência musical é para este pensamento como a disposição de notas, de pausas, de intervalos, de compassos que se sucedem numa métrica pré-estabelecida (no caso de melodias regidas ou escutadas) ou quando são executadas de forma mais livre (numa improvisação). Ressalta-se que esta é uma linguagem musical sobre a qual Kohlsdorf não se atem. Sobre a aplicação da sequência, a autora destaca que as pessoas aprendem, sobretudo, através do movimento, da sua capacidade de locomoção, o que permite a captação de um mundo em movimento, dinâmico. A autora faz referência à música, mas seu interesse maior está nas imagens, na sucessão de cenas que compõem um fenômeno de movimento. Kohlsdorf faz ainda menção à tradicional associação desse processo à cinematografia. 
A Técnica de Análise Sequencial apoia-se numa série de eventos. Este montante de eventos foi dividido em três partes: Eventos Gerais, Campos Visuais e Efeitos Visuais. Foi conveniente ater aos Eventos Gerais e apenas indicar o que venha a ser um Campo Visual. Não foram abordados os Efeitos Visuais porque são muito específicos dos estudos urbanísticos e apontam para uma análise detalhada das características pelas quais o espaço se apresenta à percepção.

Os Eventos Gerais são compostos por estações e intervalos. Para Kohlsdorf, as estações das sequências:

[...] são momentos durante o trajeto onde há registro perceptivo, ou onde ele é mais intenso; correspondem à consciência dos estímulos sensoriais que se recebe, como seleção de instantes e pontos de observação. [...] A coincidência na marcação de estações cresce em lugares com avaliação topoceptiva positiva, isto é, com altos graus de orientabilidade e identificabilidade, confirmando que existem estruturas morfológicas com estímulo mais adequado do que outras para a realização das referidas expectativas (KOHLSDORF, 1996, p. 81).

Algumas hipóteses podem ser levantadas sobre como se dá o estabelecimento de estações. Pode-se pensar, por exemplo, que as estações são recortes ou fragmentos da paisagem percebida. Que são pontos de referência. Não apenas a demarcação de pontos, mas a noção de espaçamento entre eles. Um trajeto narrado é uma ocasião cotidiana que exemplifica esta situação: prossiga pela avenida, no segundo semáforo vire à direita, na padaria vire à esquerda, etc. É como se no movimento fossem eleitas porções de espaço-tempo, que no caso representam os intervalos. Kohlsdorf explica que as estações se formam por dois motivos, primeiro porque "a percepção é seletiva" e segundo porque "as configurações oferecem informação visual de qualidades diferentes" (KOHLSDORF, 1996, p. 81).

Há considerações a se fazer a respeito da subjetividade das estações das sequências: Foi visto que a Análise Sequencial sugere a existência de intervalos e sequências nos sons, nas imagens e de um modo mais geral, na movimentação/deslocamento do ser. As cenas e os sons do cotidiano não são controláveis, pelo contrário, a sua aleatoriedade se sobrepõe às percepções. Esta arbitrariedade age de forma mais aguda no caráter seletivo da percepção do que na variabilidade das configurações. Isso porque o rápido reconhecimento dos lugares familiares é algo, por assim dizer, instantâneo. É imediato ao ponto de se poder notar 
mudanças estruturais. Agora, quanto ao nível de abrangência desse universo é predominante a subjetividade. Não se pode ver ou ouvir tudo, tampouco selecionar tudo. Logo, veem-se certas quantidades selecionadas, porções de espaço abrangidas pela vista (Campos Visuais).

Tendo sido abordada a forma da cidade, o espaço topoceptivo e a situação espacial, discutem-se, a seguir, cultura, imaginário urbano e turismo. Para tanto, julgou-se importante discorrer sobre o conceito de cultura para uni-lo ao turismo além de discernir a noção de imagem e de imaginário. Discernir é um termo adequado, já que o intento é continuar buscando significados estéticos dos ou nos imaginários sem desconsiderar que um é gerador do outro. Grosso modo, pode-se dizer que a imagem produz um imaginário que exprimirá novas imagens ou um novo imaginário e, inversamente, pode ser que a imagem degenere o imaginário. Portanto, não se pode desassociá-los. 


\section{IMAGINÁRIO, CULTURA \& TURISMO}

Assume-se que é complicado abordar conceitualmente o turismo cultural. A dificuldade começa no trabalho de se conceituar o próprio turismo. Historicamente, têm surgido tentativas após tentativas para defini-lo. Os insucessos de não se poder chegar a um consenso sobre uma concepção una do que venha a ser o turismo tem relação, dentre outros motivos, com a variedade de atividades ou modalidades que envolve. Considera-se ainda, que os aspectos danosos do turismo têm ligação direta com a inexatidão das teorizações propostas, até mesmo porque se as práticas turísticas se desenvolvessem de forma plena, se seus impactos positivos sempre superassem os negativos a procura por uma definição indefectível seria um tanto desnecessária.

Isso não quer necessariamente dizer que desvelar um conceito inquestionável seja o passo antecessor para o sucesso total de uma epistemologia do turismo. Acredita-se que neste caso o plano conceitual se desenvolve a partir do seu plano real. Ou seja, realizam-se atividades a priori e a posteriori as refletimos. É claro que também se pode planejar uma atividade para depois executá-la. Isso seria considerar o olhar do turista, que também compõe a formação desse pensamento. Sintetizando a ideia: antes de se pensar ou de se teorizar sobre turismo ele já existia e as pessoas já realizavam atividades diferentes, mas de complexidade proporcional às de hoje. Isso se comprova ao se pensar que muitas das experiências favorecidas por inovações tecnológicas como espaços virtuais, holografias, ambientes tridimensionais servem basicamente para recriar momentos históricos, artistas mortos ou descobertas que pessoas do passado puderam vivenciar. Caso das expedições de descobrimento, das viagens para assistir concertos eruditos ou a contemplação de pinturas e esculturas já não existentes. Entende-se, portanto, que o fato de o turismo angariar mais números, mais arrecadações, mais empregos a cada ano não determina o seu pleno desenvolvimento em relação ao ano anterior, significa que está mais mercadologicamente competitivo. Por isso, dentre outros motivos, as definições do turismo e as próprias atividades turísticas são segmentadas: algumas focam a experiência, outras o turista, outras o deslocamento, outras a viabilidade econômica, ambiental ou social. 
O turismo é rodeado de características próprias que se revelam constantemente e nascem continuamente. Mas o saber o que é, não é um questionamento próprio do turismo. É do homem buscar por significações, dar sentido; funcionalidade e nisso está o trabalho de se definir as coisas. Por outro lado, o próprio ser assume o papel de coisa. O homem reflete sobre sua existência e, por mais que queira, não pode determiná-la. Apesar da impossibilidade de se saber essencialmente o quê ou quem é o homem, pode-se saber muito do seu caminho e pode-se, até mesmo, fazer projeções sobre seu futuro. Nossos passos se dão através do tempo e, apesar da importância do conhecimento, do autoconhecimento, nossas ações se perfazem e escrevem nossa história sem uma concepção dada.

Numa visão macro, poderia se pensar o turismo a partir de seus momentos mais remotos às propostas dos teóricos contemporâneos de cientificá-lo. Além de enquadrá-lo no tempo, haveria de se considerar cada momento histórico que atravessou, em cada lugar que percorreu. No entanto, o objetivo aqui não está em discorrer sobre a ordem cronológica do turismo. Está mais em discutir sobre o turismo hoje, mas sem desconsiderar o seu caminho, sua multiforme e as abordagens já lhe concebidas.

Entendendo que o turismo é dinâmico, que envolve atividades distintas em diferentes lugares, por diferentes pessoas entende-se que é difícil propor ou se valer de uma única definição para este emaranhado de situações. Porém, julga-se coerente buscar por elementos e conceitos próximos a um assunto recortado, a uma circunstância mais específica. Neste caso, o turismo cultural na cidade de Brasília com vistas ao seu rock oitentista.

Uma causa para a mudança de foco, de variáveis nas definições de turismo pode ser a constante evolução dos jeitos de se fazer turismo. As mudanças de gostos, de hábitos pessoais levaram, por exemplo, à segmentação das práticas turísticas. Os conceitos macros de turismo foram desmembrados por não suportarem organizadamente as muitas modalidades ramificadas de atividade em atividade somadas às peculiaridades dos lugares. Isso tudo somou um grande organograma onde o turismo cultural é um subnível contido de outros subníveis. 
O Ministério do Turismo, por exemplo, secciona ao máximo o conceito. Elege segmentos do turismo cultural como o turismo cívico e o turismo religioso e desse emaranhado destaca atrativos como obras de arte; gastronomia típica; dança, música, teatro, cinema, dentre outros (MINISTÉRIO DO TURISMO, 2010, p. 54).

O caminho para contrapor essa segmentação exagerada seria imediatamente ou inversamente buscar por uma conceituação mais direta, mais embasada que não sugerisse uma enumeração de itens. No entanto, volta-se aos problemas conceituais do turismo. Se o próprio pensamento do turismo em si esbarra nesses percalços, quanto mais o do turismo cultural. Fugindo a esta regra, alguns autores ocupam-se em dar corpo à teoria do turismo aliando-o a disciplinas mais sólidas ao invés de compartimentarem excessivamente as atividades turísticas. Partilha-se deste princípio neste estudo principalmente, em se tratando da estratégia de aproximar os conceitos de cultura e de turismo com vistas a um entendimento do que venha a ser turismo cultural e o que venha a ser fazer turismo cultural.

Barreto (2007) faz essa correlação conceitual entre turismo e cultura. Na sessão “Turismo e Cultura: Possíveis Relações Teóricas”, a autora aponta as controvérsias do conceito de turismo (BARRETO, 2007, p. 14). No entanto, ressalta que o conceito de cultura também suscitou polêmicas por todo o século XX, o que corrobora o pensamento de que tanto o turismo quanto a cultura (no plano ideal) desenvolvem-se junto à vivência, junto ao dia a dia - "a interpretação cultural é apenas post facto" (GEERTZ, 1989, p. 18). Demonstra ainda serem, sobretudo sociais, objetos dos estudos sociológicos e antropológicos.

Cabe, aqui, utilizar pontualmente um argumento de Geertz para amarrar as ideias da forma urbana (Certeau e Kohlsdorf) à cultura como prática social: “[...] remodelar o padrão das relações sociais é reordenar as coordenadas do mundo experimentado. As formas da sociedade são a substância da cultura" (GEERTZ, 1989, p. 20). 
A intenção de se trazer essa afirmativa se torna mais clara quando se insere nela o turismo. O turismo é essencialmente um remodelador dos padrões das relações sociais. Consequentemente, tem a capacidade de mudar o rumo das experiências a serem vividas pelas pessoas. Pode ser que o rock BSB 80 não tenha sido explorado, pelo menos intencionalmente, pelo turismo, só que muito desse movimento pode ser considerado turístico-cultural. $\mathrm{Na}$ verdade, começa a amadurecer o entendimento de que conceitualmente fala-se de uma mesma coisa de diversas formas. Se as manifestações artísticas são atrativos do turismo cultural e música é arte, então tem-se o rock como um tipo de arte e de atrativo. Indo além, o rock BSB 80, feito daquela maneira, ouvido daquele jeito, naquela década, por aquelas pessoas é uma forma da sociedade brasiliense. Deveras este é efetivamente o substrato procurado, reavendo o conceito de Certeau.

Muitos autores tentam, ainda na atualidade, propor conceitos específicos de cultura para cada área trabalhada. Pozenato, Giron e Lebreton (2009) inseriram a comunicação na discussão sobre turismo e cultura. Ao sugerirem uma "abordagem integrada" entre "Cultura, Turismo e Comunicação" os autores argumentam que o avanço das tecnologias de informação é um fator predominante no desenvolvimento do turismo mundial. Sabe-se, no entanto, que fenômenos como a inclusão digital e a proliferação de certas mídias acabam por alimentar o turismo de massa que é oposto à idealização do turismo de cultura, onde grandes quantidades de turistas tomam o lugar causando danos sociais e naturais. Ao lidarem com a cultura, os autores admitem serem muitas as maneiras de concebê-la. No capítulo "Cultura, Turismo e Comunicação" os autores adotam a seguinte perspectiva:

[...] sob o ângulo sociológico, pode ser vista como um conjunto de temas, instituições e modelos de um povo. Sob uma visão artística, a cultura pode ser produtora de sentimentos e emoções. Por outro lado, pode ser vista como fonte de equilíbrio e de abertura ao mundo. [...] Essa diversidade de visões sobre a cultura provoca uma diversidade cultural que constitui a base do patrimônio de cada grupo social, o qual se manifesta por meio de suas obras, que podem ser arquitetônicas, artísticas, políticas, filosóficas, religiosas, etc. (POZENATO, et al., 2009, p. 143).

Buscar definir a cultura por cada ponto de vista possível além de "dicotomizar" e limitar a reflexão é repetir o erro de Kluckhohn - criticado por Geertz em "A interpretação das Culturas" - de se criar um conceito "sem um argumento definido a propor" (GEERTZ, 1989, p. 4) e, ainda, difuso teoricamente. 
Imergir no universo da comunicação pode não ser a forma própria para se entender o turismo cultural, mas tal associação, para este caso, remete ao quão imaginário é o mundo das comunicações urbanas, sobretudo a que se dá através da linguagem musical. Segundo Robert Park (1971), “a comunicação, à maneira da linguagem, é simbólica e impessoal, tal como é, por exemplo, a Matemática. De outro lado, é expressiva e pessoal como a música” (PARK, 1971, p. 75). O autor avança seu raciocínio distinguindo duas dimensões da comunicação, levando em conta os seus aspectos integradores e socializadores:

\begin{abstract}
De um lado serve para provocar uma difusão de traços culturais, ampliando, assim a área cultural dentro da qual são possíveis as relações sociais. De outro lado, a comunicação, na medida em que focaliza as influências culturais diversas sobre algum centro de comunicação, seja uma aldeia, ou uma metrópole, tende a introduzir novas ideias na compreensão comum (PARK, SAPIR, 1971, p. 76).
\end{abstract}

Tomam-se como exemplo, tanto para a difusão de traços culturais quanto para a introdução de novas ideias, as facilidades tecnológicas que podem provocar imaginários a partir do acesso a trabalhos musicais outrora realizados com equipamentos não tão eficazes quanto os de hoje e difundido por canais de menor alcance. É o caso do avanço dos estúdios de gravação. Atualmente uma banda pode gravar um disco em alta qualidade num home studio (estúdio caseiro). Em 80, as bandas tinham que recorrer às gravadoras. Equipamentos e técnicas de hoje permitem ainda a remasterização de áudios caseiros gravados em fita cassete. Isso faz com que com que músicas inéditas de bandas inativas sejam lançadas, causando, ironicamente, a nova - para os novos - e a velha - para os velhos - sensação de novidade.

Geertz assume a cultura como sendo uma ciência interpretativa. Corroborando com Max Weber ao assumir que o homem é um animal preso a teias de significados tecidas por ele mesmo, Geertz propõe a cultura como sendo essas teias e sua análise (GEERTZ, 1989, p. 04). Desta forma, concebe-se a cultura como uma teia de significados compartilhados entre os indivíduos, ou seja, é tecida em conjunto pelo grupo social. Entende-se, com base neste pensamento, que os bens culturais são elementos materiais e imateriais que representam estes significados possibilitando sua identificação e, no sentido antropológico da cultura, sua descrição. 
A respeito da possibilidade de descrição da cultura, Maffesoli corrobora esclarecendo que:

\begin{abstract}
A cultura é um conjunto de elementos e de fenômenos passíveis de descrição. [...] A cultura pode ser identificada de forma precisa, seja por meio das grandes obras da cultura, no sentido restrito do termo, teatro, literatura, música, ou, no sentido amplo, antropológico, os fatos da vida cotidiana, as formas de organização de uma sociedade, os costumes, as maneiras de vestir-se, de produzir, etc. (MAFFESOLI, 2001, p. 75).
\end{abstract}

Com base nesta explicação referente à possibilidade de descrição dos elementos da cultura, Maffesoli diferencia a cultura do imaginário. Em sua concepção a cultura é a materialidade que se vê, por exemplo, numa obra, seja ela uma pintura ou uma estátua. Já o imaginário é aquilo que não se vê, mas se pode sentir: a aura ou atmosfera desta obra. Para o autor: "O imaginário é uma força social de ordem espiritual, uma construção mental, que se mantém ambígua, perceptível, mas não quantificável.” (MAFFESOLI, 2001, p. 75).

Neste sentido, tanto a cultura quanto o imaginário são fatores sociais, contudo, apesar de cada sujeito estar apto para interpretar o imaginário com certa autonomia, quando se examina a fundo esta questão o que se vê no imaginário do indivíduo é muito pouco individual, mas, principalmente "grupal, comunitário, tribal, partilhado" (MAFFESOLI, 2001, p. 80).

Já a cultura é refletida no homem tanto coletiva quanto individualmente, uma vez que, segundo Geertz, ela possui a capacidade de modelar os homens como espécie única, assim como os modela como indivíduos separados. Para o autor é justamente isso que há em comum entre os homens das diferentes culturas: "nem um ser subcultural imutável, nem um consenso de cruzamento cultural estabelecido" (GEERTZ, 1989, p.38).

As muitas possiblidades de se realizar diferentes práticas turísticas num mesmo lugar são, em muitos casos, atrativo para que um indivíduo opte por conhecer determinado destino, no entanto, busca-se voltar esta reflexão às práticas culturais propriamente ditas, evitando proposições específicas quanto às segmentações turísticas. Sabe-se que nos estudos voltados ao turismo, assim como nos estudos de cultura, há autores que defendem o estabelecimento de tipologias. Barreto (2007), por exemplo, considera que entender as tipologias turísticas que 
definem os "tipos de turismo" e os "tipos de turistas" é pré-requisito para se entender o turismo cultural (BARRETO, 2007, p. 79). A autora se posiciona em favor da não generalização de turistas, justificando que eles não têm um mesmo perfil. Neste ponto discorda-se da autora. A solução deste imbróglio não se resume a aceitar a coexistência de um único tipo de turismo e de turista, mas proporcionalmente não existe um único tipo de turismo cultural e um único tipo de turista cultural.

Andrade (1995) afasta-se deste posicionamento por acreditar que:

A preocupação acadêmica com sofisticações sem maiores fundamentos que a simples especulação, as finalidades de viagens e as legislações internacionais e nacionais levaram o turismo a sofrer classificações artificiais, complexas, ilógicas e pouco funcionais [...]. Os fenômenos turísticos diversos se interligam, porque são interdependentes e complementares entre si. (ANDRADE, 1995, p. 26).

Desta forma, o fazer cultural, o turismo e suas práticas possibilitam contato e envolvimento do turista com um emaranhado de significados diferentes dos seus próprios e, ainda, permite reviver teias de significados tecidas em outra época: na visitação a uma cidade histórica, por exemplo. Onde há sociedade, há cultura. Portanto, compreende-se que falar em turismo é falar em práticas culturais o que, novamente, dispensa a necessidade de se tratar de diversos tipos de turismo como turismo de experiência, turismo cívico, turismo musical, etc.

Diferentemente da cultura que pode ser observada, interpretada e descrita por quem não pertence àquela determinada sociedade, o imaginário é sentido por aqueles que partilham de um contexto comum, ou seja, há um grupo social que poderá reviver determinado imaginário, uma vez que este é:

[...] o estado de espírito de um grupo, de um país, de um Estado-nação, de uma comunidade, etc. O imaginário estabelece vínculo. É cimento social. Logo, se o imaginário liga, une numa mesma atmosfera, não pode ser individual. (MAFFESOLI, 2001, p. 76.).

Mafessoli ultrapassa a ideia de que o imaginário é coletivo, não só não é individual como não se resume ao grupal. Para ele o imaginário está próximo da cultura, ao ponto de um estar contido no outro, no entanto obras como pinturas, fotografias, composições e suas 
imagens são produtos do imaginário. "O imaginário é determinado pela ideia de fazer parte de algo. Partilha-se uma filosofia de vida, uma linguagem, uma atmosfera, uma ideia de mundo, uma visão das coisas" (MAFFESOLI, 2001, p. 80).

Para Robert Park (1979), o imaginário é o estado de espírito de uma cidade, a própria “cidade é um estado de espírito" (PARK, 1979, p. 26). Brasília e o seu rock está para os brasilienses como não está para nenhum outro grupo, o imaginário brasiliense suscita uma maneira própria de se compor, de se tocar, de se pensar, de se ouvir rock. Sobre Paris, Mafessoli afirma: “O imaginário de Paris faz Paris ser o que é”, em conformidade adequa-se: O imaginário de Brasília faz Brasília ser o que é. Suas características, como o fato de ser uma cidade nova, de ter sido planejada, não faz dela uma cidade menos detentora ou menos geradora de imaginário. O imaginário ultrapassa questões físicas e estruturais. Na verdade, a ideia de uma cidade planejada ser erguida está na construção do seu imaginário.

Brasília foge à regra das cidades turísticas que angariam grandes fluxos turísticos. Atividades desenvolvidas junto à natureza ainda são as grandes movimentadoras do turismo e, sob esses termos, Brasília não pode concorrer com grandes destinações do ramo. No entanto, sabe-se que muitos lugares assim sofreram desequilíbrios causados pelo turismo de massa. $\mathrm{O}$ turismo em Brasília está mais voltado para atividades urbanas, destacam-se os eventos, contemplação da arquitetura e do patrimônio, celebrações cívicas, entretenimento noturno e outras manifestações artístico-culturais.

Pelo que se tem na teoria do turismo, todas estas podem ser consideradas atividades relacionadas ao turismo cultural. A seguir, explana-se sobre as técnicas utilizadas na obtenção de dados, posteriormente, a discussão destes permitirá um maior aprofundamento das questões levantadas relativas ao rock, ao imaginário e ao turismo cultural em Brasília. 


\section{O ESPAÇO PRATICADO \& O ROCK BSB 80}

\subsection{MÉTODOS E TÉCNICAS}

Segundo Denzin e Lincoln (2006), a pesquisa qualitativa é um campo de investigação que atravessa disciplinas e temas, tem histórias independentes e distintas nas diversas áreas. Sugere a ênfase sobre as qualidades das entidades, processos e significados que não são examinados ou medidos experimentalmente em termos de quantidade, volume, intensidade ou frequência. As autoras afirmam que os pesquisadores qualitativos relevam:

[...] a natureza socialmente construída da realidade, íntima ligação entre o pesquisador e o que é estudado, e as limitações situacionais que influenciam a investigação. Busca soluções para as questões que realçam o modo como a experiência social é criada e adquire significado" (DENZIN; LINCOLN, 2006, p. 23).

Voltando a questão do imaginário, este se refere a uma "força social de ordem espiritual, uma construção mental, que se mantém ambígua, perceptível, mas não quantificável” (MAFFESOLI, 2001, p. 75). Portanto, esta pesquisa não poderia constituir-se de outra abordagem que não a qualitativa.

Na construção do método de pesquisa, na coleta de dados e na interpretação fez-se uso da obra Pesquisa Qualitativa com Texto, Imagem e Som - Um Manual Prático de Martin W. Bauer e George Gaskell (2002). Esta coletânea serviu de auxílio a este estudo na construção da estratégia metodológica. Tal compilação de técnicas e procedimentos não difere num todo de outras obras metodológicas, sobretudo das de abordagem qualitativa. Foi relevante porque se trata de um livro voltado para trabalhos que têm como fonte de dados sociais os textos, as imagens e os sons. Isso não quer dizer que a presente pesquisa inclinou-se para uma investigação estritamente textual ou audiovisual, mas sim para o levantamento, discussão e interpretação de documentos e depoimentos. Diferentemente da análise musicológica, por exemplo, que focaliza a estrutura interna da música. 
A análise social científica toma aspectos da música e os correlaciona a padrões externos de recepção e produção. Logo, as tentativas de se considerar a música como dado social pressupõem uma relação entre os sons e o contexto social que os produz e os recebe. Desta mesma forma foram concebidos aqui os textos e as imagens.

Foi realizada uma pesquisa documental que consistiu num apanhamento de materiais textuais e consulta a registros audiovisuais. Apesar de ser parecida com a pesquisa bibliográfica, a pesquisa documental se difere na natureza das fontes, "vale-se de materiais que não receberam ainda um tratamento analítico, ou que ainda podem ser reelaborados de acordo com o objeto da pesquisa" (GIL, 2002, p.45). Além de analisar os documentos de "primeira mão", existem também aqueles que já foram processados, mas podem receber outras interpretações.

As fontes de dados da pesquisa documental, no que se refere aos textos, foram letras de músicas do rock BSB 80; escritos oficiais e não oficiais; artigos acadêmicos; artigos de revista, jornal impresso e da internet; consulta a acervos públicos e privados. Fotografias, vídeos e filmes são tipos de imagem que auxiliaram a caracterização do rock BSB 80. Quanto aos sons, tratou-se de consulta a melodias e áudios de entrevistas de artistas e do público adepto ao rock BSB 80 .

Foi feito um levantamento das bandas do rock BSB 80 assim como de seus álbuns e músicas na busca por conhecimento mais rebuscado dessas obras. A finalidade foi distinguir, ou melhor, localizar o rock BSB 80 entre outros estilos musicais, de outros lugares, de outros períodos. É dada ênfase a estas três variáveis do objeto devido a sua conexão com a construção de imaginários.

Este elo entre um estilo musical, uma cidade-cenário num recorte temporal ocorreu em outros tempos noutros lugares. A cidade do Rio de Janeiro junto e a Bossa Nova dos anos 50/60 montam um bom exemplo. Assim como o samba, atravessando o século. Também o rock carioca dos anos 80 . 
Apegando-se ao caso do Rio de Janeiro, transcreve-se a seguir a letra da bossa "Rio", de Roberto Menescal (1963), que traz aspectos da paisagem do Rio de Janeiro e a ligação de seus cidadãos com a praia, com o mar:

\author{
RIO \\ Roberto Menescal \\ Rio que mora no mar \\ Sorrio pro meu Rio \\ Que tem no seu mar \\ Lindas flores que nascem morenas \\ Em jardins de sol \\ Rio, serras de veludo \\ Sorrio pro meu Rio \\ Que sorri de tudo \\ Que é dourado quase todo dia \\ E alegre como a luz \\ Rio é mar, eterno se fazer amar
}

\title{
$[\ldots]$
}

Esta letra, numa rápida interpretação, produz ou reproduz a imagem que as pessoas tinham e têm da cidade do Rio de Janeiro. Há um processo social de construção de um imaginário que envolve, inclusive, os sujeitos que não conhecem a cidade, a cidade física. $\mathrm{O}$ lugar nasce, no plano ideal, a partir desses versos e se reafirma nas sensações das notas e do ritmo da bossa nova. Não é uma finalidade ater-se a este caso, este é apenas um prelúdio do sentido com que serão trazidas letras do rock BSB 80 para discussão. Ressalta-se que não se trata de uma pesquisa linguística, e sim de uma reflexão realizada a partir de outras reflexões: dos compositores que compuseram as músicas, por exemplo, junto aos aspetos teóricos e às percepções captadas por meio da realização de entrevistas.

A entrevista é um recurso metodológico que busca, com base em teorias e pressupostos definidos pelo investigador, recolher respostas a partir da experiência subjetiva da fonte, selecionada por determinadas informações que se deseja conhecer. Desta maneira, os dados não são apenas colhidos, mas é também resultado da interpretação e reconstrução pelo pesquisador, em diálogo crítico com a realidade. Nesse percurso de descobertas, as perguntas permitem explorar um assunto ou aprofundá-lo, descrever processos e fluxos, compreender o 
passado, analisar, discutir e fazer prospectivas. Possibilita ainda identificar problemas, microinterações, padrões e detalhes, interpretações, caracterizar a riqueza de um tema e explicar fenômenos de abrangência limitada (DEMO, 2001, p. 10).

As entrevistas realizadas foram do tipo semiestruturadas em profundidade. $\mathrm{Na}$ entrevista semiestruturada "o entrevistado tem a possibilidade de discorrer sobre o tema [...] sem se prender à indagação formulada" e na entrevista em profundidade "o informante é convidado a falar livremente [...] sobre o tema [...] as perguntas do investigador buscam dar mais profundidade às reflexões" (MINAYO, 2010, p. 64). Portanto, este tipo de organização das entrevistas, sob estímulos do entrevistador, auxiliado por um roteiro de questões, dá liberdade ao entrevistado de refletir e se expressar sobre o tema e sobre assuntos periféricos, porém pertinentes a ele. Ao mesmo tempo, situa o entrevistado quanto aos objetivos da pesquisa sem despeça-lo do foco do trabalho.

Apesar de o levantamento documental e as entrevistas serem técnicas distintas optouse por unir no levantamento, discussão e interpretação, os dados obtidos por meio destes dois instrumentos. Os arquivos já acessados auxiliaram a formatação das questões e facilitaram a interação com os entrevistados, assim como, a realização das entrevistas trouxe informações sobre como avançar na busca por documentos.

Já que na própria coleta uma ferramenta serviu a outra, optou-se por não tratar os dados dos documentos e das entrevistas separadamente. Ao invés de utilizar uma técnica de análise correspondente a cada amostra de dados decidiu-se discuti-los juntos numa única sessão intercalando letras de músicas com relatos, imagens e entrevistas avançando na caracterização do rock BSB 80 aliada à teoria e encaminhando a confirmação ou refutação das hipóteses de pesquisa na resposta aos objetivos do trabalho e ao problema de pesquisa.

Quatro entrevistas foram realizadas. Este número foi considerado suficiente devido ao satisfatório retorno dos entrevistados. Sendo assim, adianta-se que no exame, descrição e discussão de todo o material coletado foram enfatizados os depoimentos e as informações sobre os projetos dos quais cada entrevistado participa ou participou. Foram entrevistados Néio Lúcio Moraes Barreto, mentor do projeto Cabeças - Centro Brasiliense de Arte e Cultura (compreendido por seus representantes como sendo uma sociedade, Sociedade 
Cabeças); Paulo Mattos, cantor, flautista e compositor da banda Mel da Terra; Rodrigo Leitão, vocalista da banda Finis Africae e André Noblat, coordenador do Movimento Brasília Capital do Rock.

A banda Mel da Terra é da época do Cabeças. Ambos foram criados no fim da década de 70. A Finis Africae surgiu em 1984, no auge do rock BSB 80. Já o Movimento Brasília Capital do Rock é recente, foi lançado em 2012.

$\mathrm{Na}$ discussão dos dados atentou-se à ordem cronológica dos acontecimentos. Portanto, iniciou-se com as narrativas de Néio Lúcio e Paulo Mattos sobre as origens e trajetórias do Cabeças e da Mel da Terra interagindo-as com a teoria, com imagens, letras de músicas e outros materiais concernentes ao rock BSB 80. Posteriormente foram trazidas contribuições de Rodrigo Leitão, com perspectivas sobre o momento mais efervescente do rock BSB 80 e de André Noblat que se manifestou, dentre outras questões, quanto à afirmativa de que Brasília é a capital do rock e que este tipo de posicionamento evoca potenciais artístico-culturais e turísticos da cidade.

\subsection{APRESENTAÇÃO E DISCUSSÃO DOS DADOS}

O Cabeças foi um projeto atuante em Brasília no fim dos anos 70 a meados dos 80. O projeto consistiu, inicialmente, na reunião de pessoas na superquadra 311 Sul. Lá eram desenvolvidas atividades como apresentações musicais, pintura, recitais, dentre outros. Néio Lúcio explanou sobre o momento de Brasília quando do surgimento do Cabeças:

O Cabeças surgiu em 1978. Ainda era um regime militar. Eu diria que um regime militar já desgastado. Ou seja, continuava sendo regime militar, mas não tinha mais aquela fúria, só que ninguém comunicou isso à população. "Olha, nós já não somos tão militares como éramos antes. Já não temos tanta agressividade como tínhamos antes. E nossos poderes também não são tão exacerbados como eram antes, nos momentos mais críticos". Mas ao mesmo tempo não se anunciou isso para comunidade, que ainda vivia sob o regime autoritário em que a palavra de ordem era: "Circulando, ó, circulando!". Não se podia aglomerar, se juntar. Isso obviamente fez com que as pessoas não descessem dos prédios onde moravam, fez com que elas não 
utilizassem as quadras como um quintal coletivo [...] não permitiu que se começasse a cidade, que a maquete começasse a ganhar vida, alma, qualidade [...] não permitiu esse espaço ser usufruído por famílias, por unidades de vizinhança. Isso que foi interrompido. As pessoas passaram a morar nos pombais.

A gente não sabe exatamente se teria sido assim sem o regime militar. Ou se teria sido assim com ou sem o regime militar. Essa dúvida ficou no ar.

O fato é que ficou todo mundo ausente. A rua tinha um distanciamento, era uma coisa meio proibida, e as pessoas viviam de apartamentos em apartamentos, visitando uns aos outros. No que diz respeito à questão artística, vivia-se aguardando notícias de alguma coisa do Rio e de São Paulo que viria para cá. Aí então se criava um evento social com uma roupa bacana, todo mundo ia se encontrar naquele lugar. Mas nascer um trabalho artístico na cidade, isso era meio inconcebível. Não se tinha isso. E se existisse não arrebanharia público. Então, esse era o quadro.

Esta fala descreve como os resquícios da ditadura militar influenciavam a vida social. A cidade não contava com eventos artísticos próprios, o que as pessoas faziam era absorver o conteúdo das mídias que chegavam e aguardar outras novidades do eixo Rio-São Paulo.

Já artista de teatro, Néio Lúcio se viu incomodado com tal inércia artística. Ele explicou como considerou aliar seu conhecimento em dramaturgia a uma iniciativa que pudesse mudar o quadro atual que tanto o inquietava:

A década de 70 foi uma década rica no teatro brasiliense. Ali começaram a surgir as manifestações e as criações. Por exemplo, "O homem que enganou o diabo e ainda pediu troco”, que originou o Teatro Galpão. Depois as peças que se seguiram, como o "Escreve, escritor, escreve", que é da minha autoria inclusive; "Os Saltimbancos" e várias peças que fizeram sucesso e construíram a vida do teatro brasiliense. $O$ "Ary Para-Raios" com o "Esquadrão da Vida" [...] tinha música ao vivo! Nos "Saltimbancos”, por exemplo, tinha uma banda ao vivo com o Nei Rosauro, o Nanche Las Casas, que eram os roqueiros da Margem, edição de 70 e pouquinho, além do Dênis Bigela e outros.

O que era o Cabeças? Para mim era o seguinte: era um basta a uma situação estranha. Eu trabalhava pra caramba, ficava ensaiando meses uma peça de teatro, para apresentar pra família, pros amiguinhos. Não tinha público, não tinha uma ligação entre aquilo que se produzia e a cidade, um público da cidade. 
As pessoas que faziam existiam. Eu conhecia gente que fazia umas poesias legais pra caramba. Falava: "Cara, que voz!” Eu conhecia um cara que tocava um piano maravilhoso, o outro tocava um contrabaixo, todo mundo isolado.

Eu conhecia, porque era o circuito de apartamento em apartamento, ou de barzinho em barzinho. Eram endereços muito pertinho um do outro, não a rua como uma praia, ou como um calçadão de uma superquadra, para as crianças descerem do prédio e se encontrarem embaixo. Não tinha essa característica.

Aí, eu sabendo de todo esse potencial me incluía nele, que na arte significa que você está falando para as pessoas a partir da sua linguagem específica, que é a arte que você está gritando, falando, reclamando coisas ou propondo coisas. Isso que é o teatro, isso que é a própria música. Toda essa linguagem se comunica; e toda linguagem que se comunica e não tem um retorno, ela faz "assiiiimmmm" e morre. Se ela tem retorno, ela se realimenta e responde. Então esse ciclo é que faz com que o artista cresça, adquira melhor capacidade de linguagem, enfim, se sinta parte de alguma coisa. Essa coisa nem existia. Tudo era ali doméstico. Eu fico lá, recebo o meu amigo, toco um "bluesinho" ou uma composição da época, mas jamais o cara sonhava em mostrar sua composição.

Eu dava aula no Cresça, meus alunos me questionavam: - "Ah, legal, fazer teatro é bom, mas, se eu quiser viver disso, não é fácil." - "Eu sei, não tenho como te responder. Estou dando aula aqui para vocês mal e "porcamente" e, quando eu faço a peça de teatro, é duro na queda pagar aluguel, conta, não sei o quê, porque inclusive a galera está atrelada a uma família e tudo o mais, que não era o meu caso, porque eu era órfão, então tinha que me bancar". A gente saía de uma peça de teatro e ia para uma boate: Caco, Shalako, e dali que saía a peça seguinte. Se eu não estivesse lá, fatalmente eu poderia não estar na peça seguinte, porque ela nascia do afetivo ali, do dia a dia da galera. "Vamos fazer isso? Vamos". Não era uma coisa de seleção de atores. "Vamos chamar esse cara, porque ele realmente tem um potencial enorme para fazer esse papel". Isso só veio a existir depois. Então o que precisava existir era uma atitude de ocupação de espaço público. "Tanto gramado, tanto espaço limpo, e a gente aqui é tudo meio preso". E essa foi uma das motivações da criação do Cabeças. A segunda é essa dos meninos quando perguntavam: "E eu posso viver disso?". "Caraca, e se eu não investir na criação de uma situação onde se diga: existe arte nesta cidade! Quando alguém anunciar que vai tocar um violão na sala tal, por favor, vá porque é legal o que ele toca!" Mas como é que a gente vai saber que é legal? Porque eu botei numa filipeta? Porque eu anunciei no jornal e não atrelei isso a um palco? Isso não vai dar certo. Então eu tenho que criar a situação de levar esses acontecimentos até o público. Onde eles estão? Na casa deles, que eram as superquadras. Tenho que fazer disso um evento que faça com que eles desçam e comecem a usufruir da qualidade dos poetas da cidade, dos músicos, dos artistas plásticos. Essa era a ideia, enxertar as quadras dessas coisas. 
O Cabeças tem uma ligação direta com o rock BSB 80 e com o imaginário por ele criado. Foi um projeto que tirou pessoas do âmbito individual, sobretudo artistas, o que encaminha esta reflexão para o entendimento de que o rock BSB 80 se deu a partir da apropriação coletiva do espaço, do que nele se fez e se fabricou, de acordo com Certeau (1994): "feituras de espaço" (CERTEAU, 1994, p. 207). Confirma, ainda, o pensamento de Maffesoli (2001) de que a construção do imaginário se dá na coletividade. Esta dinâmica não foi nutrida apenas pelo Cabeças, como será visto mais a frente, mas este foi o ponto de partida. Néio Lúcio relatou como se dava a ocupação dos espaços urbanos pelo Cabeças:

As pessoas se tornaram uma equipe [...] cada um ia se agregando [...] tornando cada vez mais evidente de que a ocupação estava no caminho certo. [...] Começou a ter uma recepção fantástica porque a ideia era supersimples, mas era de uma pertinência incrível, e é essa pertinência que fez ser uma coisa que está até hoje na memória afetiva da cidade.

Nós criamos o Concerto Cabeças ao ar livre dentro da quadra, inicialmente na 311 Sul. O que era isso? Era um palco, nem era palco, era calçada. Palco veio lá na frente. Era uma calçada, um equipamento que a gente buscava, da melhor qualidade dentro das nossas possibilidades. As pessoas traziam de casa inclusive, o Rodolfo Cardoso, Renato Vasconcelos, o Oswaldo Montenegro, todo mundo vinha e trazia o que podia da sua casa, juntava ali na calçada e ali acontecia o concerto. Você sentava no gramado, várias pessoas vinham de bicicleta, outras vinham a pé, outras desciam dos prédios motivados por aquele encontro colorido, bonito, sereno. 


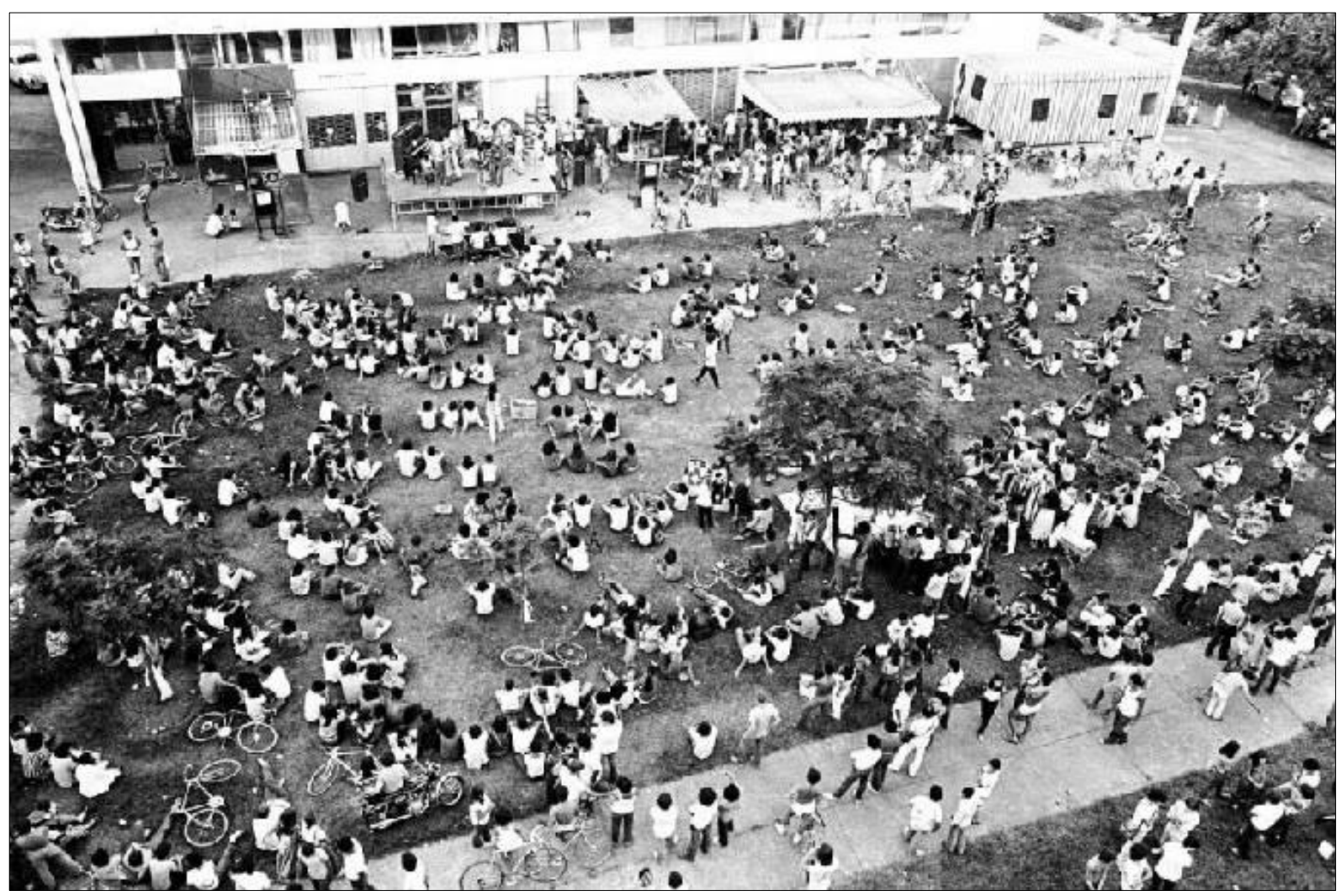

Figura 03: Concerto Cabeças na $311 \mathrm{Sul}$

Foto: Autor desconhecido

[...] Eu cuidava prá caramba, primeiro, para não ser um palanque político-partidário e contrário à ditadura militar. "Estamos aqui, porque o nosso direito foi tolhido e nós vamos ocupar este gramado, porque nós somos cidadãos brasilienses!". [...] Eu me policiava até não poder mais para eu não me empolgar com o microfone e fazer daquilo o meu discurso, um cenário desequilibrado. Mesmo que eu tivesse razão, seria desequilibrado.

Eu cuidava para ser um bate-papo entre as pessoas que ficavam ali. E dizia, "Pô, olha aqui um cara superlegal. Então ele sentava na grama e conversava com você. Tinha o Oswaldo, que trouxe um violão e fez umas composições incriveis. Depois eu dizia: "Olha, se alguém quiser trazer um anúncio de alguma coisa". E alguém dizia: "eu queria avisar que tem um negócio de uma festa no Lago Norte”. Eu dizia: "Claro"! "Anuncie você mesmo!". Quando eu não sabia quem era, eu evitava, para não correr o risco do "mostro" que aparece na hora de um microfone. O microfone amplia a voz, a pessoa pega o microfone e começa a gritar. É uma empolgação às vezes indomável. 
Então, eu batia papo com as pessoas, dizendo: estamos aqui sentados, é bom, né? Eu não discursava. Era um ato, uma ação. Não tinha discurso por trás: "A razão de estarmos sentados aqui é porque nós temos esse direito". Não. A gente tem o direito de estar sentado morrendo de rir e outro tocando e deitado na grama, feliz da vida, com a namorada, e outros lá no prédio lá em cima, um senhor olhando. Pois é, aí uma música gostosa que tá tocando [...] A própria policia, quando passava, olhava e pensava: "Que legal, o que a gente pode fazer: não estão fazendo nada demais, não estão gritando". Então era uma coisa sutil, como se fosse a água se esparramando e entrando na maquete. Era a alma humana da cidade que estava se manifestando e ganhando o seu espaço.

[...] Ali tocou Renato Vasconcelos, Oswaldo Montenegro, Luli e Lucinda, Hermeto Pascoal [...] Ali nasceu o Mel da Terra.

Antes de tratar mais sobre o Cabeças e sobre surgimento do Mel da Terra, conjunto precursor do pop rock em Brasília, coube tecer ${ }^{1}$ um breve retrospecto do rock no mundo e no Brasil para aclarar como os grupos musicais de Brasília adotaram estilos, ou subgêneros, do rock como o punk rock e o pop rock.

\subsection{O ROCK NO MUNDO, NO BRASIL, EM BRASÍLIA}

O rock evolui constantemente, desde o seu nascimento na década de 50 nos Estados Unidos, até os dias de hoje em todo o mundo. A remota origem deste estilo musical abrangente é resultado de um misto de jazz, ragtime, blues, country music, rhythm and blues que se fundiram num só para posteriormente se desmembrar em diversas vertentes das quais as mais contemporâneas ao surgimento do rock foram os subgêneros rock and roll e rockabilly. O primeiro registro de rock foi gravado em 1950 pelos Saddlemen que em 1952 passaram a se chamar Bill Halley and the Comets. Em 1955 gravaram Rock Around the Clock, considerado o primeiro hit do rock and roll. Surgiram então, alavancando o rock and roll, Chuck Berry, Elvis Presley, dentre outros.

\footnotetext{
${ }^{1}$ Com auxílio da obra: História da música, da era da pedra era do rock (MONTANARI, 1988).
} 
No fim dos anos 50 e início dos 60 a Inglaterra passou a incorporar o rock, sobretudo, após o surgimento dos Beatles e dos Rolling Stones. O rock na Inglaterra tomou grandes proporções a ponto de concorrer e intercalar com os norte-americanos o primeiro lugar em público e vendagem de discos.

Após o rock expandir e consolidar-se na Inglaterra ocorreu o que é conhecido como "intelectualização" do rock, impulsionada pelo surgimento de mais um subgênero: o rock progressivo. O rock já não consistia em batidas lineares de bateria, bases sistemáticas de contrabaixo e riffs previsíveis de guitarra. A ordem da vez era a junção com outros ritmos e a introdução de novos instrumentos. O rock progressivo se baseava, sobretudo, na experimentação. Foi característica dessa fase a efervescência de tendências e contínuo surgimento de vertentes, tanto que o subgênero progressivo não enquadra toda essa mutação. Da metade dos anos 60 até os 80 surgiram o rock psicodélico, glam rock, hard rock, heavy metal e punk rock.

O início dos anos 80 foi marcado pelo surgimento dos subgêneros do punk rock. Durante a década surgiu ainda o new wave, o pós-punk, o glam metal e o rock alternativo.

No Brasil, o rock foi introduzido em 1955 com a interpretação de Rock Around the Clock (Max C. Freedman, James E. Myers, 1952) por Nora Ney. Em 1957, foi lançado Rock and Roll em Copacabana (Miguel Gustavo, 1957), o primeiro rock original em português, gravado por Cauby Peixoto. Na segunda metade dos anos 50 surgiram Celly e Tony Campello e no início dos anos 60 The Jet Black's, The Jordans, The Clevers (bandas instrumentais) e Ronnie Cord. No meio da década de 60 o rock nacional foi representado pelos artistas da Jovem Guarda, estando à frente Erasmo Carlos, Roberto Carlos e Wanderléia. Os Mutantes completam a lista dos destaques dos anos 60. Na década de 70 surgem Secos e Molhados, Rita Lee (carreira solo), Casa das Máquinas e Raul Seixas. Neste momento, o rock nacional começou a produzir seus próprios subgêneros a partir de novas experiências que tendiam a introduzir, por exemplo, elementos da música sertaneja e do baião. 
O rock BSB 80 seguiu linhas tanto nacionais quanto internacionais. Os subgêneros identificados são o pop rock, punk rock, rock progressivo, rock experimental e gótico. Dentre as bandas pertencentes a tais estilos destaca-se: Aborto Elétrico, Arte no Escuro, Banda 69, Capital Inicial, Cinco Generais, Detrito Federal, Elite Sofisticada, Escola de Escândalo, Finis Africae, Legião Urbana, Mel da Terra, Plebe Rude e Tellah. Ressaltando que essas são bandas que "saíram da garagem", que conseguiram algum prestígio no meio musical. Capital Inicial, Legião Urbana e Plebe Rude alcançaram maior sucesso, tiveram e ainda tem significativa vendagem de discos. As outras não atingiram tal status. No entanto, estavam num grau de popularidade maior do que o das bandas que não se mostraram. É como se existissem três camadas: âmbito nacional, âmbito local e anonimato. Nesta última estão as bandas que não chegaram fazer apresentações expressivas ou que eram compostas por adolescentes que despontaram apenas no início dos anos 90, dentre outras situações.

Muitas foram as bandas em atividade no rock BSB 80, esbarra-se, portanto, na dificuldade de não se poder conhecer todas. Há mais facilidade, evidentemente, em colher informações sobre as que atingiram público e fama. Mas o rock BSB 80 não se resume a apenas estas, uma vez que, existe no meio rock a ideia de que é no underground, no "lado b" que o movimento se sustenta. Esta máxima foi ressaltada na reportagem de Irlam Rocha Lima do Correio Braziliense sobre o lançamento do primeiro álbum da banda Escola de Escândalo, em 2014: "Depois de Legião Urbana, Capital Inicial e Plebe Rude, a Escola de Escândalo, mesmo sem ter lançado nenhum disco, tornou-se a banda mais cultuada do Rock Brasília” (Correio Braziliense, 2013).

Os jornais, revistas, sites, blogs e demais veículos que tratam do assunto conflitam algumas informações, como a datação da origem de bandas, sobre qual é a "pegada" de uma ou outra e mesmo se determinada banda pertence aos anos 80, se é remanescente de 70 ou se já prediz a década de 90. Estas incoerências indicam que buscar primeiramente pela música e posteriormente pelo artista pode ser mais proveitoso para este trabalho. Argumenta-se ainda que algumas bandas citaram muito Brasília nas letras, outras nem o fizeram. Portanto, julgouse importante selecionar letras que fazem referência à cidade, às coisas da cidade, tendo vista o objetivo e o recorte espacial do estudo. Se esta pesquisa se ocupasse de um levantamento ou de um estudo de caso do rock BSB 80, provavelmente, todas as letras poderiam ser comtempladas, porém são proveitosas para esta investigação as letras que trazem elementos 
do viver em Brasília, dos lugares da cidade, de situações que "experienciam" as pessoas em Brasília. Somente através de uma minuciosa busca às letras se pôde discriminar que músicas são essas. Para tanto, foi feita uma consulta ao site Letras.mus.br - site de letras, traduções, cifras e player para ouvir músicas e assistir clipes desenvolvido pela empresa Studiosol (C) 2001 - 2014 - o mais acessado da categoria no Brasil segundo o Alexa Internet Inc. - serviço de internet pertencente à Amazon.com, Inc (C) 2012 - 2014 - que mede quantos usuários de internet visitam um sítio da web.

A partir deste levantamento elegeram-se bandas/músicas com o critério de que algumas destas trazem em si aspectos de Brasília outrora citados e/ou fortes ligações e influências musicais, rítmicas e/ou melódicas do rock BSB 80. Outras bandas/músicas podem apresentar os mesmos elementos, no entanto a porção trazida para cá são de textos na íntegra ou trechos que indicam diretamente os elementos que compõem os objetos interessantes a esta investigação.

Músicos trocarem de banda, ou um integrante estar simultaneamente inserido em dois ou mais projetos musicais e mesmo um membro ser demitido e outra banda o admitir são situações recorrentes no âmbito musical. Isto ocorreu em Brasília. Muitas bandas não coexistiram, elas trocaram, compartilharam músicos entre si e quando uma acabava outra nascia a partir de novas junções. Circunstância do tipo vivenciou Fê Lemos, baterista do Aborto Elétrico, que se tornou músico da Capital Inicial. Marielle Loyola, que foi vocalista da Escola de Escândalo ocupou posteriormente o mesmo posto na Arte no Escuro. Eduardo Espinoza, baterista da Escola de Escândalo, e Paulo Coelho, guitarrista da Arte no Escuro, tocaram juntos na Detrito Federal.

A Legião Urbana foi a banda que alcançou mais fama, mídia e continua a repercutir. Além disso, possui, em relação às outras bandas, uma grande quantidade de músicas que falam de Brasília. Decidiu-se não utilizar músicas da Legião Urbana pelo motivo de já existir muito conteúdo na mídia e no meio acadêmico que tratam do trabalho e influência desta notável banda. Além do mais, a fase efervescente de composição e praticamente toda a de produção e gravação da Legião Urbana ocorreu no Rio de Janeiro, não em Brasília. Aqui, por se tratar de um trabalho sobre percepção, imaginário e outras nuances sociais optou-se por explorar um campo menos notado, sem desconsiderar as obras de Renato Russo, mentor, 
vocalista e compositor da Legião Urbana. Seu trabalho será ponderado nas letras da banda Aborto Elétrico, que teve toda trajetória em Brasília, e em trechos de suas entrevistas concedidas a jornais, revistas, etc.

De volta ao Cabeças e ao surgimento do Mel da Terra, Néio Lúcio afirmou:

[...] foi ali que eles se conheceram: "Ai que legal”. "Ó, esse cara é pianista; esse aqui deixa eu te apresentar, é um violonista; este aqui é um flautista legal, o Paulinho, que fica aí tocando com o Haroldinho e o Remi". Ah, e o Paulo que era filho de um amigo também. "Ó, toca contrabaixo", "Ah, que legal, vamos nos juntar ai". Por que eles vão se juntar? Porque tem um palco que todo mês está ali, ele existe, é real ,é uma ferramenta. "Então eu vou. Vamos juntar e ensaiar uma música e de repente até compor uma. Ai a gente vai lá e toca”. Olha a força desse palco! E assim nasceu não só o Mel da Terra, como vários outros menos expressivos, vamos dizer assim, que se conheceram ali.

Paulo Mattos comentou sobre o Cabeças e explicou mais detalhadamente o início do Mel da Terra:

O Cabeças serviu de fomento, de incentivo para muitos artistas surgirem no mercado porque não havia nenhum espaço que funcionasse este celeiro. Então a partir do momento em que se cria o movimento que abre esse espaço as bandas já começam a se formar porque têm aonde se apresentar. Então esse movimento foi muito importante nesse sentido e a gente se conheceu durante todo esse processo do Cabeças.

Existiam os concertos Cabeças onde eu fui vendo e escolhendo músicos nas apresentações até que resolvi, com o Sérgio Pinheiro, montar a banda. O "Sergião" veio de São Paulo e ficou hospedado no Cabeças, eu já era do movimento, participava desde cedo. 


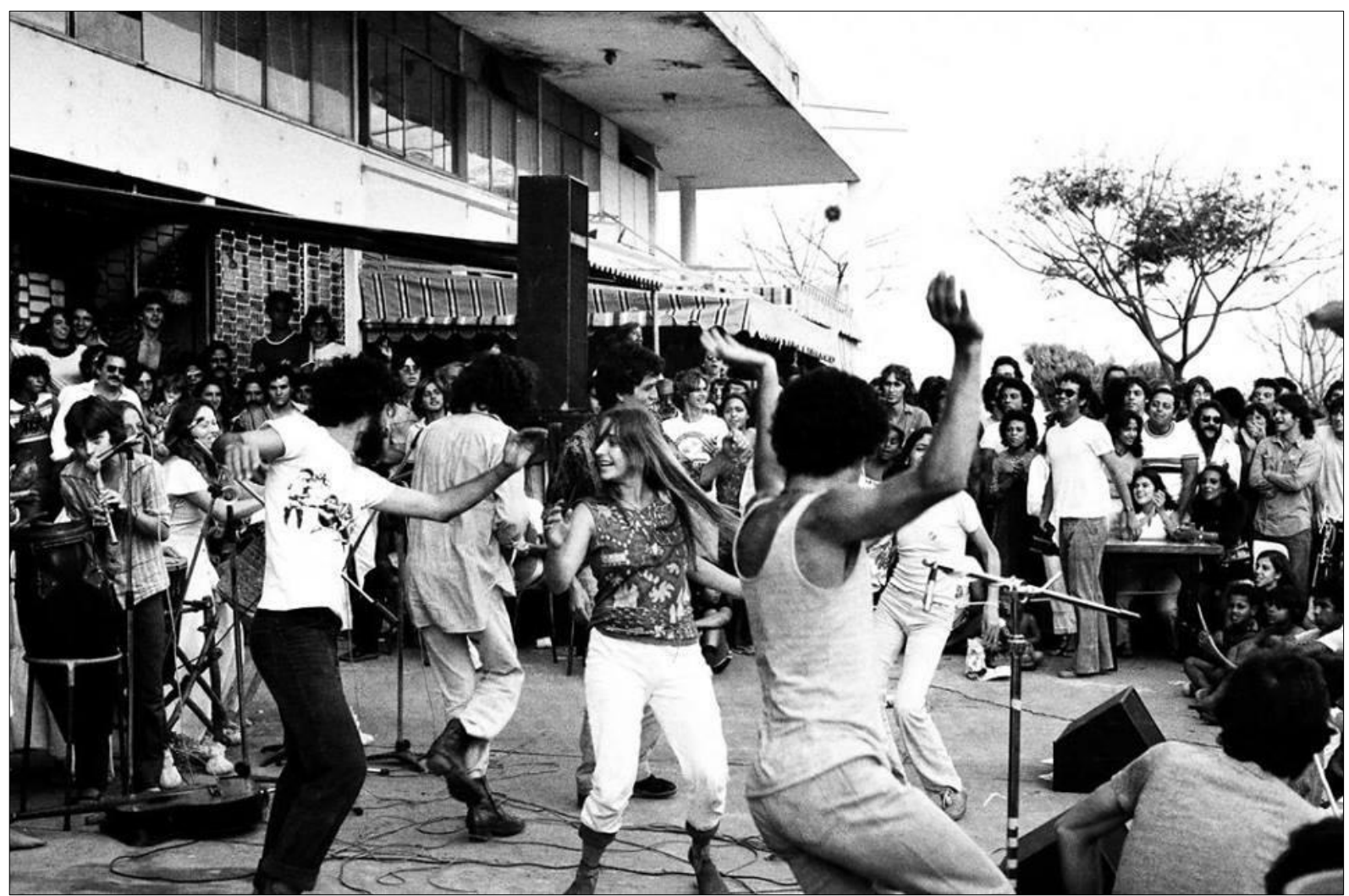

Figura 04: Concerto Cabeças (Detalhe: Paulo Mattos na flauta)

Foto: Autor Desconhecido

No dia em que o Sergião chegou, foi até engraçado, era uma loja com um subsolo, um térreo, um jirau e uma sobreloja e eu ouvi um violão lá embaixo, não sabia quem estava tocando, no subsolo. Eu estava no jirau com um pintor, porque era um espaço de todos os artistas, ele estava fazendo um trabalho lá, o Sidarta, era o nome do pintor que estava trabalhando. Eu estava tocando uma flautinha lá, curtindo ele pintar. Eu ouvi o violão lá embaixo e comecei a tocar, acompanhar o violão sem nem saber quem estava tocando. Começamos a tirar um som sem se ver, era o Sérgio. Eu falei, poxa! Fui lá, o conheci e a gente começou a trabalhar juntos, ensaiamos alguns trabalhos com vários músicos até que a gente, vendo tocar nos concertos Cabeças, foi colhendo a dedo os músicos. Chamamos o pianista, chamamos o baterista, chamamos todo mundo e montamos o Mel da Terra. A banda nasceu assim, quer dizer, bem dentro do Cabeças mesmo. 
As letras do Mel da Terra não fazem referência literal à Brasília, mas a sonância da banda indica suas origens, dá sinais do porque é proveniente de um projeto como o Cabeças. Na música Estrela Cadente, por exemplo, destaca-se o maduro arranjo melódico com influências do rock progressivo, com slides e distorções de guitarra, piano, teclado e flauta.

\title{
ESTRELACADENTE
}

\author{
Mel da Terra \\ Composição: Paulo Maciel/Edbert Bigeli \\ Cai dos ares, vem dizer \\ O caminho da esperança \\ Vem deixando rastros \\ Como um feixe de luz \\ Rasga aquele manto escuro \\ Que nos cobre, todas as noites \\ Vem trazer a lembrança \\ De séculos que passaram \\ Sobre nossas Cabeças \\ Dentro de nossas Cabeças
}

$$
[\ldots]
$$

A reportagem de Irlam Rocha Lima sobre os 30 anos de criação do Mel da Terra fala sobre o LP da banda e sobre a música Estrela Cadente:

[...] Com ares de filho de hippies, o grupo, formado por adolescentes de 15 a 18 anos, tornou-se o queridinho do público no período de 1980 a 1983 [...] Desse LP, de produção independente, saiu um clássico brasiliense, a doce balada Estrela Cadente que faz parte da memória afetiva de muitos quarentões. O LP obteve a impressionante vendagem de 25 mil cópias (CORREIO BRAZILIENSE, 2009).

Pode-se dizer que em fins de 70 e início dos 80 a frente rock de Brasília se distinguia em duas correntes: O punk rock, do Aborto Elétrico, por exemplo, e a proposta paz e amor do pop rock do Mel da Terra. Um trecho da música Tédio, do Aborto Elétrico denuncia essa diferença: “quando escurece, eu fico a fim de aprontar”. Wolf Schneider (1960) predizia que a “origem da delinquência juvenil reside incontestavelmente na necessidade de sair da 
monotonia regularizada e da gritaria oca da vida metropolitana e meter-se numa aventura qualquer" (SCHNEIDER, 1960, p. 284). Este mesmo autor detalha, antes da difusão da cultura punk, o comportamento desses grupos tipicamente urbanos:

\begin{abstract}
Na sua maioria [...] não cometem crimes. Contentam-se com protestar no penteado, no modo de vestir, na conduta contra o mundo urbano infinitamente enfadonho dos adultos. Dão a si nomes próprios [...], despejam de rádios berrantes nos ouvidos de velhos senhores, cargas de música barulhenta. Tais músicas [...] são excelente meio de expressão do protesto e provavelmente são ao mesmo tempo uma tentativa de penetrar por meio de tons e gestos febris nas escuras profundezas que a cidade fechou (SCHNEIDER, 1960, p. 284).
\end{abstract}

Trechos das canções Brasília, da Plebe Rude, e Tédio concordam sobre algumas características de Brasília. A lógica da cidade funcional é manifestada num tom de "a cidade funciona em razão do poder público, não para nós”. A presença de elementos urbanos como concreto, prédios, máquinas e carros confirmam essa ideia:

\title{
BRASÍLIA
}

Plebe Rude

Composição: Philippe Seabra/André X/Gutje/Jander Bilaphra

Capital da esperança

(Brasília tem luz, Brasília tem carros)

Asas e eixos do Brasil

(Brasília tem mortes, tem até baratas)

Longe do mar, da poluição

(Brasília tem prédios, Brasília tem máquinas)

mas um fim que ninguém previu

(Árvores nos eixos a polícia montada)

(Brasília), Brasília

\section{Brasília tem centros comerciais}

Muitos porteiros e pessoas normais

As luzes iluminam os carros só passam

A morte traz vida e as baratas se arrastam

(Utopia na mente de alguns...)

Os prédios se habitam as máquinas param

As árvores enfeitam e a polícia controla

(Utopia na mente de alguns...)

Oh.. O concreto já rachou! 
"O concreto", em duplo ou mais sentidos, pode ser interpretado como sendo o antônimo de abstrato. Realidade e utopia se confundem, tanto na perspectiva cidade-cidadão, quanto o contrário.

Em Tédio, é explícito o sentimento de insatisfação por não se ter nada para fazer na cidade. Esta situação remete à fala de Néio Lúcio sobre a falta de atividades que unissem as pessoas, quando a Brasília era isolada e não integrava o circuito dos eventos, das manifestações, dos shows. Paulo Mattos reafirmou isso ao relembrar um termo usado pela juventude na época: Brasília era "Bras Ilha".

\section{TÉDIO}

Aborto Elétrico

Composição: Renato Russo

Moramos na cidade, também o presidente E todos vão fingindo viver decentemente Só que não pretendo ser tão decadente não Tédio com um $\mathrm{T}$ bem grande pra você

Andar a pé na chuva, às vezes eu me amarro Não tenho gasolina, também não tenho carro Também não tenho nada de interessante pra fazer

Tédio com um $\mathrm{T}$ bem grande pra você

Se eu não faço nada, não fico satisfeito

Eu durmo o dia inteiro e aí não é direito Porque quando escurece, eu fico a fim de aprontar

Tédio com um $\mathrm{T}$ bem grande pra você Porque moro em Brasília, moro em Brasília

Outra atitude dos punks foi não considerar rock o que não fosse punk rock. O punk é contestador, imponente, o pessoal do pop rock, do teatro, das artes plásticas acolheu isso, quando citam rock é referência ao punk rock. Esses grupos passaram a coexistir, inclusive num outro projeto de Néio Lúcio, a Feira de Música. Ele explicou que "a Feira de Música foi um dos lugares de maior densidade de encontro do rock de Brasília, [...] foi aonde o rock e o Cabeças mais se encontraram”. 
Néio assim detalhou o projeto Feira de Música:

Era toda segunda-feira, no teatro Galpão. [...] Você tinha que se inscrever para tocar. [...] Era uma oficina para as pessoas se apresentarem e para também exercitarem. Por exemplo, podia se inscrever para iluminação. Então era um programa bem legal, de variedades. Aí começou com um pianista solitário que ia lá e se inscrevia: "Pô, eu quero tocar". Então ele ia tocar duas músicas. Eram cinco grupos ou pessoas tocando duas músicas cada, na noite. Cara, não passava carro na W2. A W2, que era logo ali atrás, 508, hoje Espaço Renato Russo. Ali ficava uma multidão de gente que não conseguia entrar, porque o galpão lotava com média mais ou menos de quinhentas e poucas pessoas dentro, e no Teatro Galpãozinho do lado, eu criei com o Leo Neiva, um parceiro, um garotão que sempre me ajudava, genro do Lauro Campos, o Jogo de Cena, que não é do James, nem é do Pipo ou do Welder nem nada. A criação disso é lá atrás, eu e Leo Neiva, ali na 508. Ou seja, tinha, olha só, segundafeira à noite, o Teatro Galpão, e, no mesmo horário ao lado, o Jogo de Cena. Ambos os teatros lotados e um público enorme do lado de fora. Eu botava duas câmeras dentro e botava as televisões para as pessoas que ficavam de foram verem o que estava rolando lá dentro. Aí já estou também influenciado com a multidão de gente atrelada ao projeto. Mas só que eu acho que tinha uma qualidade enorme o projeto.

Apesar de haver, na Feira de Música, todo um planejamento, inscrição e rodízio nas apresentações os punks não acolheram este formato democrático. Néio Lúcio esclareceu que na Feira de Música:

[...] tocava samba, coral. Chegou a ter quatrocentas e tantas pessoas inscritas no livro e eu seguia a ordem da inscrição. A única alteração que eu fazia era quando tinha rock, rock, rock. Aí eu pegava o primeiro rock, pulava, botava caipira, coral e montava os cinco daquela semana.

Os darks, os punks também se inscreviam. O Renato Russo mesmo ensaiava lá, o Aborto Elétrico, com o mesmo equipamento que eu deixava lá para uso.

O público do rock começou a lotar cada vez mais e aumentou a quantidade desse público dentro da Feira de Música. Começou a aumentar e começou também a bater perna e não querer as outras coisas que não fossem rock. Essa variedade, ecletismo que rolava na Feira, não interessava muito para eles não. Eles queriam banda de rock. Começavam a vaiar, a intimidar em alguns casos, algumas apresentações que não fossem rock. 
Os punks se sobrepunham na atitude, nas manifestações de repúdio ao governo e às formas da sociedade, no boicote a ideologias e expressões contrárias às deles. Por outro lado, os pertencentes a estilos musicais mais "brandos", como pop rock, se voltavam contra a musicalidade do punk rock. Para eles as músicas do punk rock eram pobres, principalmente os aspectos melódicos. Os progressivos, os pop desenvolviam melodias bem trabalhadas, solos arrojados, técnicas vocais e instrumentais. Já no punk rock as músicas tinham basicamente três acordes, compassos lineares e vocais gritados. Paulo Mattos também comentou essas divergências:

Nos dois estilos, nos dois movimentos existiam pessoas que eram uma cabeça aberta, universal. Outras não. Dentro da nossa banda, por exemplo, tinham pessoas que eram contra o rock. Algumas não curtiam e por isso criaram inimizades e até rixas. O Sérgio e eu não. A gente gostou do novo. Tudo que é novo pra gente é interessante. Pessoas como Renato Russo e Dinho Ouro Preto do Capital Inicial nunca tiveram preconceito com o som que era feito antes. Eles vieram com as propostas deles, mas sem aquela coisa de que o resto era ruim. Eles não tinham essa cabeça e nós também não. Porém, muitas pessoas que participavam do movimento punk queriam sumir o que foi construído antes e os que participavam do movimento que foi construído antes não queriam um som "musicalmente desestruturado", que era mais uma proposta de atitude do que de musicalidade. Era difícil entender isso por que na época se valorizava muito o conhecimento técnico para se tocar um instrumento, a influência da música clássica ainda era mais forte do que hoje.

Politicamente foi interessante por que é legal a coisa da contestação que o rock trouxe, da ironia e tudo. Mas por outro lado se perdeu muito em termos de uma construção mais elaborada, de uma preocupação maior com a estética que também tem o seu valor. Nenhuma das duas coisas tem de ser desvalorizadas.

A Aborto Elétrico foi a primeira banda punk rock de Brasília, uma das primeiras do Brasil. A Detrito Federal, ainda ativa, é outra banda de punk rock dos anos 80 . Um aspecto a se considerar é a estética do punk rock: Eram extravagantes o comportamento, as roupas e penteados. Pichar era também considerada uma atitude punk. 


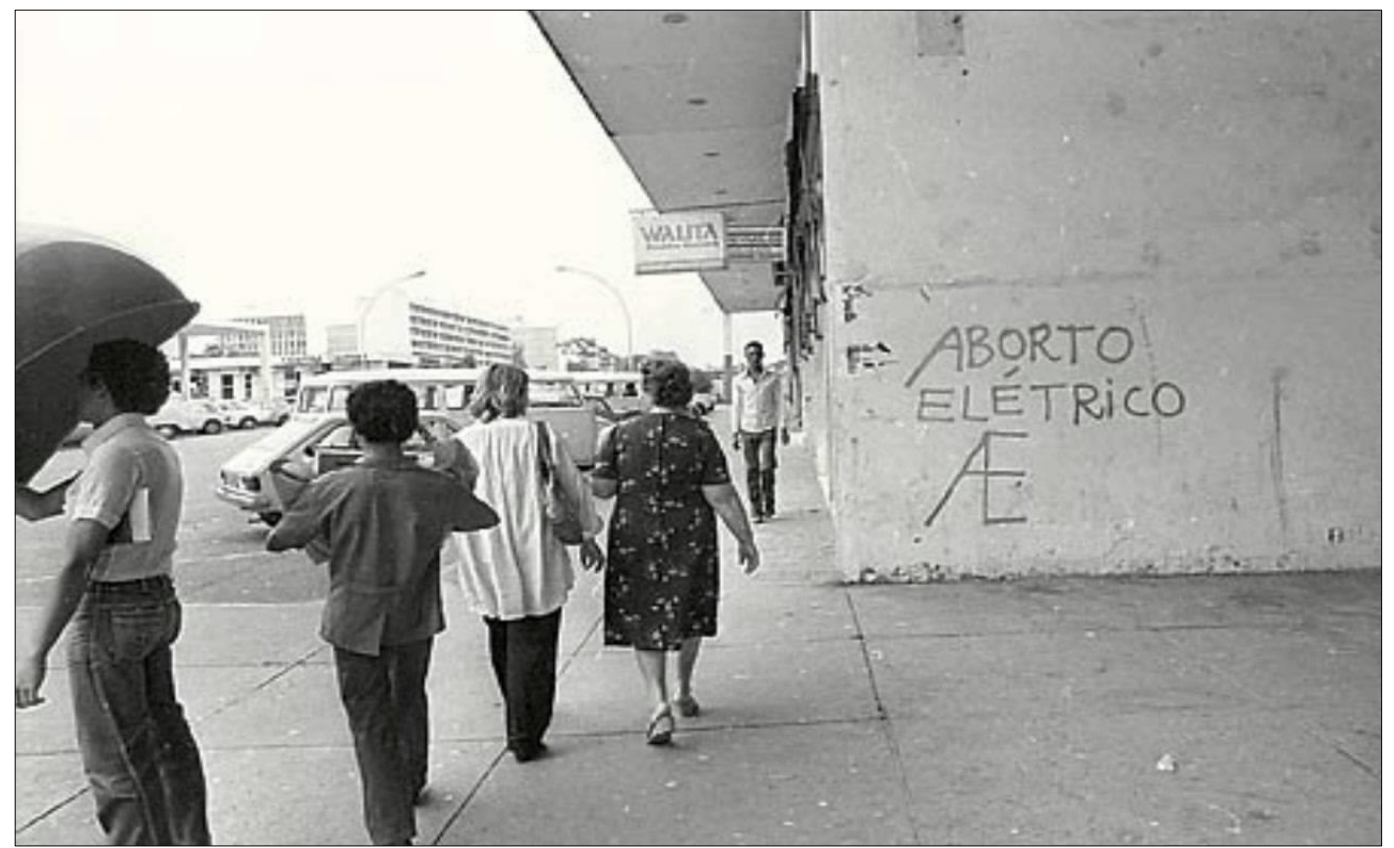

Figura 05: Pichação "Aborto Elétrico"

Foto: Autor desconhecido

O Aborto Elétrico, como o pessoal do Cabeças, valorizava as apresentações abertas. "Ao ar livre" é uma expressão bastante encontrada nos registros. A figura 06 mostra uma dessas apresentações:

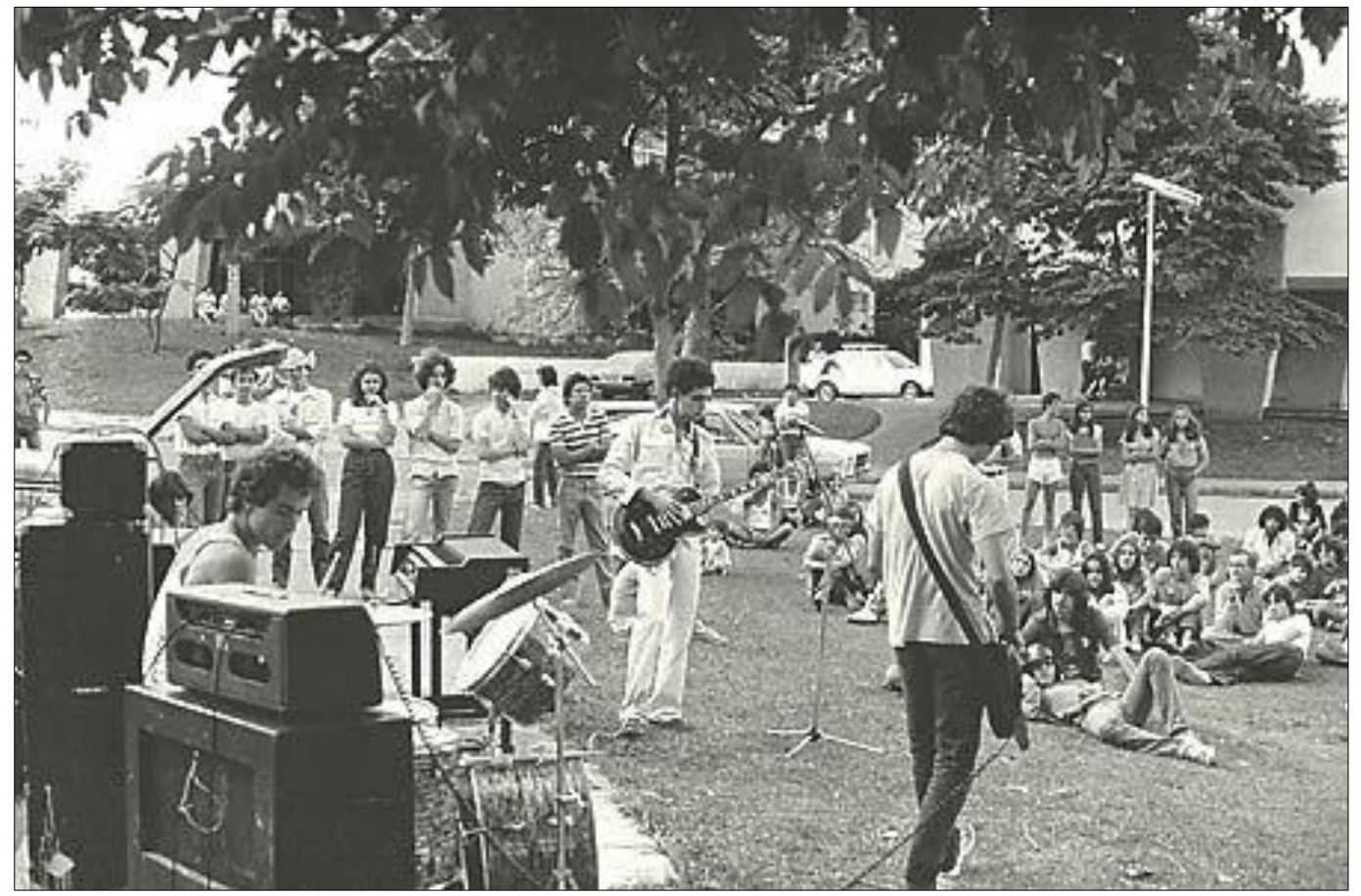

Figura 06: Aborto Elétrico na 208 Sul Foto: Luís Acioli 
Os espaços que compreendiam as superquadras eram bastante utilizados para as manifestações do rock. Com o aumento da aglomeração de pessoas na 311 Sul, os Concertos Cabeças passaram a acontecer também na 312 Norte, posteriormente no Parque da Cidade e nas Regiões Administrativas de Brasília. Muitos outros espaços foram apropriados pelo rock BSB 80, dentre eles destacam-se a Colina-UnB, o Teatro Galpão e o Galpãozinho (atual Espaço Cultural Renato Russo), o Gilberto Salomão e o Gilbertinho (Centro Comercial do Lago Sul). Em reportagem concedida ao Bom Dia DF (2015), Alexandre Podrão, vocalista da Detrito Federal, falou sobre o Gilbertinho:

[...] bandas foram formadas aqui. Aqui era a grande catedral, o templo do rock. Era onde as pessoas faziam os jornaizinhos da época, os famosos fanzines, as resenhas, artigos sobre os discos que saiam lá fora. Punks, roqueiros, periferia, playboys reunidos no meio da elite, como isso? Brasília era isso! Isso era o legal de Brasília! Aglutinava. Aglomerava. Tinha gente que vinha de fora, do Rio, de São Paulo: "nós queremos conhecer o Gilbertinho". Era, para eles, uma espécie de Baixo Leblon ou Circo Voador (REDE GLOBO, ( $)$ 2000-2015).

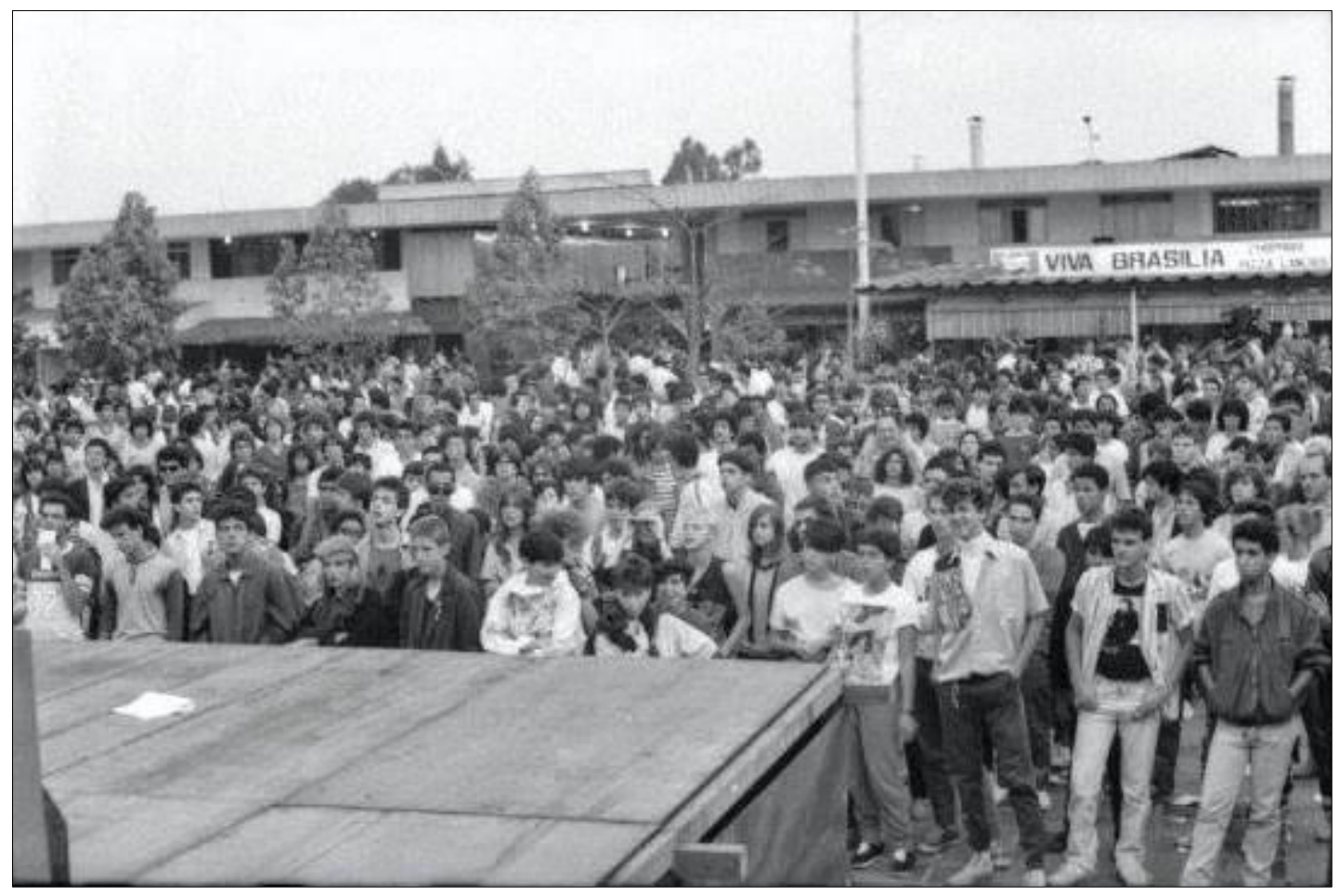

Figura 07: Gilberto Salomão em 1984

Foto: Ricardo Junqueira 
Esse apelo, para a ocupação dos espaços, para a participação das manifestações direcionadas ao rock foi feito por Marielle Loyola, vocalista da Escola de Escândalos. No programa Mixto Quente (1985), da Rede Globo, a frontwoman anunciou: “[...] você sabe o que significa duzentas e cinquenta bandas numa cidade como Brasília? É muito amigo! Procure Brasília! Visite Brasília! Conheça as músicas de Brasília!” (GLOBOSAT, ® 2003 2013). Naquela oportunidade Legião Urbana e Plebe Rude também se apresentaram. O canal se referiu às três bandas como "o time que representa o rock de Brasília".

Sobre a apropriação do espaço pelo rock, os músicos Paulo Mattos e Rodrigo Leitão foram questionados da seguinte forma ${ }^{2}$ : Assume-se, neste trabalho, que em Brasília a apropriação social do espaço ocorre primordialmente sob duas óticas: a da administração e a do cidadão. A apropriação do espaço pelo pelos cidadãos ocorre quando os indivíduos e comunidades têm condições de manifestar suas diferenças, o que possibilita a transformação do espaço para satisfazer e expandir necessidades e possibilidades da coletividade. Levando em conta as atividades, as práticas voltadas ao rock, como se dava a apropriação do espaço nos anos 80 em Brasília?

Paulo Mattos assim respondeu:

Era a época do regime militar. Então, aglomerados de pessoas eram reprimidos, eram literalmente reprimidos. A polícia chegava $e$ dispersava. Com o governo do Figueiredo, rolou a proposta da abertura. Eles viram que não daria para sustentar aquilo, perante o mundo e o próprio Brasil, por muito tempo, começaram um processo gradual de redemocratização. Então surgiu a brecha para a gente ocupar os espaços públicos com uma iniciativa pacífica, o Cabeças era uma iniciativa de ocupação de espaço para o fazer cultural, para a convivência harmônica, era uma proposta de paz e amor, era aquela época da rebarba do movimento hippie.

\footnotetext{
${ }^{2}$ Roteiro de questões - Apêndice A.

3 1979-1985.
} 
Era uma coisa que tinha uma inocência - entre aspas -, mas que era muito importante como um movimento de revolucionar mesmo a ocupação dos espaços públicos que nos eram proibidos na época e a cultura era a nossa forma de dar a nossa palavra, embora a gente tivesse que fazer dribles na censura, por exemplo, o próprio Mel da Terra, tinha música censurada, quando a gente queria falar de sexo, não podia, nem política. A gente tinha que falar, por exemplo: "como é bom brincar de trepar numa árvore, frutifera, frutificar". Tinha que ter todo um drible, aí a censura não pegava aquilo. Aí no show você parava na palavra, como eu fiz aqui agora, enfatizava e dava outro sentido porque eles não deixavam passar nada. Então realmente, as brechas que foram aparecendo nós fomos aproveitando e uma foi o Cabeças que se aproveitou, que era realmente essa oportunidade de ocupar os espaços públicos. A gente queria fazer a cultura da quadra, só que aquilo foi crescendo tanto que virou cultura da cidade, depois começou a virar identidade cultural da cidade. Aí os processos de construção, de procedimentos mesmo de produção foram amadurecendo até que se criaram conselhos de cultura, ou seja, toda evolução, até da política pública de cultura veio daí. Tanto que o pessoal ligado a esse movimento, como o Guilherme, que era do Saltimbanco, hoje é secretário de cultura. É uma turma que realmente ajudou a construir a identidade cultural da cidade.

Rodrigo Leitão foi o primeiro vocalista da Finis Africae. Nascida em 1984, passou por reformulações, mas está ainda em atividade. A Finis Africae era uma banda que experimentava. $\mathrm{O}$ nome $^{4}$ foi inspirado ${ }^{5}$ pelo romance O Nome da Rosa (Humberto Eco, 1980). Na trama, Finis Africae é, mais especificamente, o nome de uma das repartições de uma misteriosa biblioteca que escondia obras que não seriam aceitas pela igreja. A temática africana pode também ter relação com a presença de instrumentos percussivos nas músicas da Finis Africae, o que demonstrava ousadia já que a inserção de tais elementos no rock era uma novidade, sobretudo no rock brasiliense.

\footnotetext{
${ }^{4}$ Tradução literal: "a extremidade da África” - Google tradutor ( 2015.

${ }^{5}$ Informação retirada da página oficial da banda.
} 
Para Kohlsdorf, “o espaço urbano é apreensível a partir de suas manifestações externas, em etapas de sucessão cognitiva onde se desenvolve um movimento de objetivação de informações" (KOHLSDORF, 1996, p. 50). A cerca da apropriação do espaço Rodrigo Leitão afirmou que:

Não havia espaço para a manifestação cultural do rock propriamente dito. Havia projetos culturais organizados por pessoas ligadas a cultura ou por bares e restaurantes alternativos. O promotor cultural Néio Lúcio, com apoio da Secretaria de Cultura, conseguiu abrir uma programação para artistas se apresentarem, era o Concerto Cabeças! O Bom Demais, um bar da Asa Norte, além do Metropolitan, Radicaos, Cafofo, Rolla Pedra, etc. Iniciativas privadas, também abriam espaço para os grupos. Mas foi na rua, por iniciativa própria das bandas, que o rock de Brasília aconteceu. Eram estacionados caminhões, as carrocerias eram transformadas em palcos mambembes e as bandas tocavam. O público se juntava e de repente tinha 5 mil pessoas. Isso ocorreu na entrequadra 110-11 Sul, gramadão da 114 Sul, 113 Sul, 307-308 Norte, Gilberto Salomão, Ermida Dom Bosco e na entrada do Lago Norte.

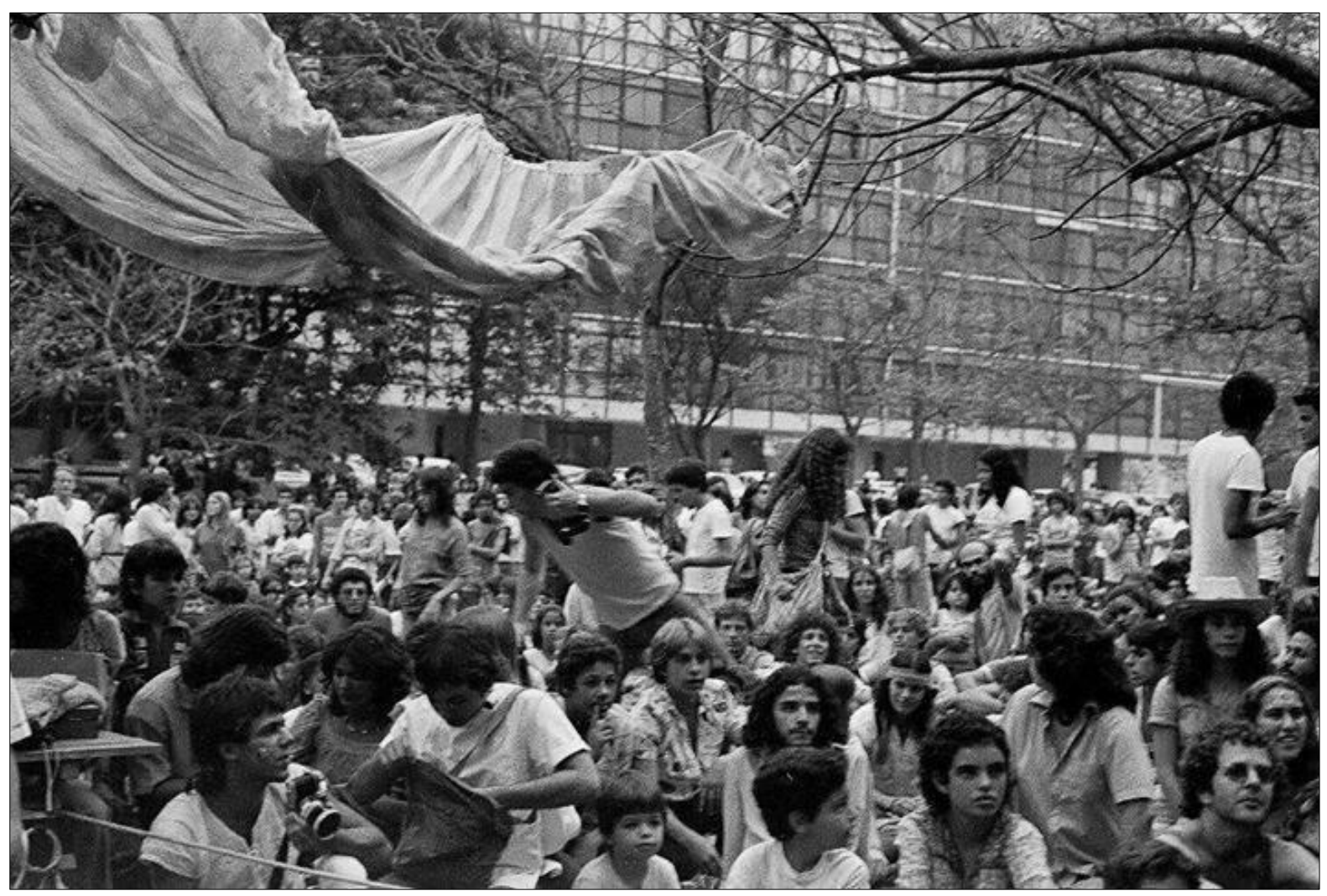

Figura 08: Rock na Quadra Foto: Autor desconhecido 
Para Maffesoli (2001), não se pode ver a aura que envolve uma obra, mas se pode sentir. Este algo a mais, que supera o feito é o que se busca apreender através do imaginário, por intermédio do imaginário.

Em 1989 foi lançado o livro Cabeça que propunha preservar a memória do Cabeças e da cultura de Brasília. Na apresentação do livro, Maria Christina Diniz Leal ${ }^{6}$ afirma que "a proposta do Cabeças procura romper a 'aura' que tradicionalmente envolve a obra de arte e busca torná-la objeto de mais fácil acesso, libertando-a da mística das galerias e teatros [...]" (LEAL, In LÚCIO, GUERRA, 1989, p. 10).

Inteirar-se sobre as sensações que envolvem as atividades realizadas, coletivamente, "ao ar livre", sobre o envolvimento das pessoas no criar, no produzir, difundir, ouvir, compor, tocar, cantar, ocupar e apropriar demonstra que a atmosfera que envolve o rock BSB 80 é composta de afeto.

Os entrevistados foram questionados quanto ao sentimento de ter vivido os anos 80 em Brasília, de ter presenciado e mesmo participado do rock BSB 80. Assim se manifestou Néio Lúcio:

Eu tenho um amor imenso por esta cidade. Tenho um olhar que vê uma porção de coisas, mas percebo que não são muitas pessoas que veem. Eu não estou atribuindo a mim uma qualidade, genialidade, eu não fiz isso não. Toda a minha história na cidade, minha vivência na história acumulada, faz com que eu simplesmente enxergue algumas coisas que estão ali e que não são, às vezes, vistas por algumas pessoas, porque simplesmente o olhar não está treinado para olhar. Eu vim para cá antes da inauguração. Então usei o espaço urbano de Brasília, maquete, as superquadras, as ruas, atravessava para ir pro Cine Brasília, pro Cine Cultura, ia lá pro Iate Clube de Brasília velejar, curtir a beira do lago. Dar a volta no lago era um negócio assim monumental.

\footnotetext{
${ }^{6}$ Chefe de gabinete de Ruy Pereira da Silva, na época, diretor-executivo da Fundação Cultural do Distrito Federal.
} 
Eu vivi tudo isso quando criança. Antes da ditadura e durante a ditadura. Ela não chegou até a mim por uns anos, até porque a fúria dela, publicamente, não secretamente, mas publicamente, só veio explodir mesmo lá para 68: pau nos estudantes.

Até lá ficaram umas coisas de decretos ali e muitas maldades ocultas. Mas, publicamente, de confronto, porrada aparecer na mídia, isso foi lá para 68, ou seja, com 8 anos já de existência de Brasília. Para o mundo da criança, não dos adultos, a gente ia vivendo nas quadras, aquela coisa toda. Isso entrou em mim.

Vira e mexe o Cabeças aparece, mas é mais pelo viés histórico de recuperação, do que de atividade propriamente dita. Atividades hoje o Cabeças não tem. Teve recentemente o Cabeças Brancas, que nós colocamos no Parque. Não foi exatamente um resgate. Foi um acontecimento, um evento, que oportunamente aconteceu naquela época e que não desencadeou e gerou consequências. Regularidades que eram matérias-primas do Cabeças. Toda e qualquer atividade que nós fazíamos eram normalmente plantadas para serem regulares, serem programas, para exatamente entrar numa cidade sem hábitos. Para construir hábitos saudáveis, legais, etc, numa cidade desacostumada ao hábito da novidade. Ela era uma cidade de novidades. Mas foi interrompida em 64 com o Golpe Militar, foi impedida do seu sonho.

O Cabeças está na memória afetiva da cidade como se fosse uma coisa que aconteceu ontem. E na verdade isso já tem trinta e tantos anos. Quando as pessoas falam do Cabeças, não falam como se fosse saudade, elas falam: "Ah, o Cabeças!", como se fosse uma coisa ainda sendo vivida de tão importante que foi nessa relação afetiva das pessoas, dos artistas.

Foi a sensibilidade no fazer do dia a dia do Cabeças é que fez com que ele funcionasse muito bem. $O$ Cabeças fez mais de 200 atividades ao ar livre e, jamais, houve nem um início de briga. Nunca. Nunca. Nunca teve um "Gente, para com isso!" Nunca. Porque parece que ele nasceu de um jeito que todos éramos o Cabeças. Todos éramos. E quando chegava, você sentia que era parte daquilo. Você não era um espectador, até porque, quando você sentava, você olhava pro lado e tinha uma porção de pessoas que eram da sua tribo no sentido de que eram da sua cidade, que você conhecia de alguma forma; e se não conhecia você tinha vontade de dizer oi, porque você já tinha visto algumas vezes. Se algumas pessoas estranhas chegavam, elas chegavam em minoria absoluta. Tão absoluta que elas ficavam intimidadas pela energia, que é essa que era a real e que compunha essa ocupação da maquete. [...] Esse foi o espirito do Cabeças e foi assim que ele se manifestou na cidade. 
O jargão "Brasília é a Capital do Rock" existe há algum tempo. É relativo à quantidade e qualidade de bandas que surgiram em Brasília nos anos 80. Deve-se ainda ao sucesso da Legião Urbana que se tornou a banda mais evidente do país. Até meados de dois mil, o que havia sobre a temática eram especulações, até que um grupo cunhou o termo e criou o Movimento Brasília Capital do Rock. André Noblat, um dos coordenadores do movimento e vocalista da banda brasiliense Trampa, narrou o surgimento do movimento:

É um movimento que surge de uma discussão cultural sobre como Brasília não aproveita a marca que ela mesma criou. Surgiu de uma provocação feita há alguns anos atrás, uma discussão na câmara legislativa, numa homenagem ao Marcos Pinheiro, radialista que faz o programa Cult 22, programa que toca rock há mais de 20 anos, que toca coisas da cidade. Ele estava sendo homenageado e eu estava voltando de uma viagem à Salvador. No aeroporto me deparei com aquele bando de propagandas de axé. Eu não gosto de axé! Mas eu entendi aquilo como um sendo um produto baiano. $O$ axé é baiano! Passando pelo aeroporto eu vi que todas as lojas tocavam axé, de roupa à bijuteria; todos os cds e dvds que estavam nas vitrines eram de axé; você respirava axé porque é uma cidade que valorizou essa ferramenta. De lá saiu Caetano Veloso, Gilberto Gil, existe uma série de outros ritmos da Bahia que não sejam axé, mas o axé foi um produto que eles exportaram e criaram todo um ciclo econômico em volta deste produto. Exportaram as micaretas, fizeram o carnaval baiano crescer por meio do axé, vendem roupas ligadas ao axé, música e uma série de outros produtos.

Quando você desce no aeroporto de Recife, a primeira coisa que se vê é uma placa "seja bem vindo a capital do frevo". Eu sou pernambucano. Eu vou à Recife várias vezes durante o ano. Frevo, só tem no carnaval. Recife tem rock, tem samba, brega, tem frevo. Uma cidade com quatrocentos anos leva duzentos pra consolidar uma marca como o frevo. $O$ axé surgiu mais recentemente, mas numa cidade de trezentos anos. Tem também o samba no Rio. Você tem Brasília com cinquenta e cinco, que na década de oitenta, há mais de trinta anos atrás, quando ela tinha vinte e poucos, consegue criar no imaginário popular do Brasil que aqui é a capital do rock. E a cidade nunca tirou proveito disso. Isso não em detrimento de nenhum outro estilo musical, até porque aqui é um dos grandes centros do choro, por exemplo. Mas Brasília não vai ser a capital do choro. O choro veio do Rio de Janeiro, do samba. Brasília é a capital do rock porque o Brasil reconhece, mas isso vai se perdendo. 
O poder público e a cidade não souberam ganhar dinheiro com isso, gerar turismo com isso, dar mais espaço para a cultura e para a arte de Brasília através disso. Então, o movimento surge dessa observação. As mais de mil bandas existentes na cidade com pouco espaço e pouco apoio pra tocar, o movimento surge desta demanda também. Ou seja, a gente tem potencial de público, potencial artístico, as maiores bandas de rock do país saíram de Brasília, a maioria das grandes bandas de rock. Hoje, a gente tem uma geração de músicos, se brincar, melhor do quê a antiga, mas que não tem mais mídia, porque não existe mais gravadora, tem uma dificuldade de sair daqui maior que se tinha antigamente. Brasília não investe, não valoriza, não utiliza isso pra ganhar dinheiro, não cria ações, etc. Então, o movimento surge dessa discussão com produtores, jornalistas, músicos. Daí esse movimento veio crescendo e em 2012 ele foi lançado.

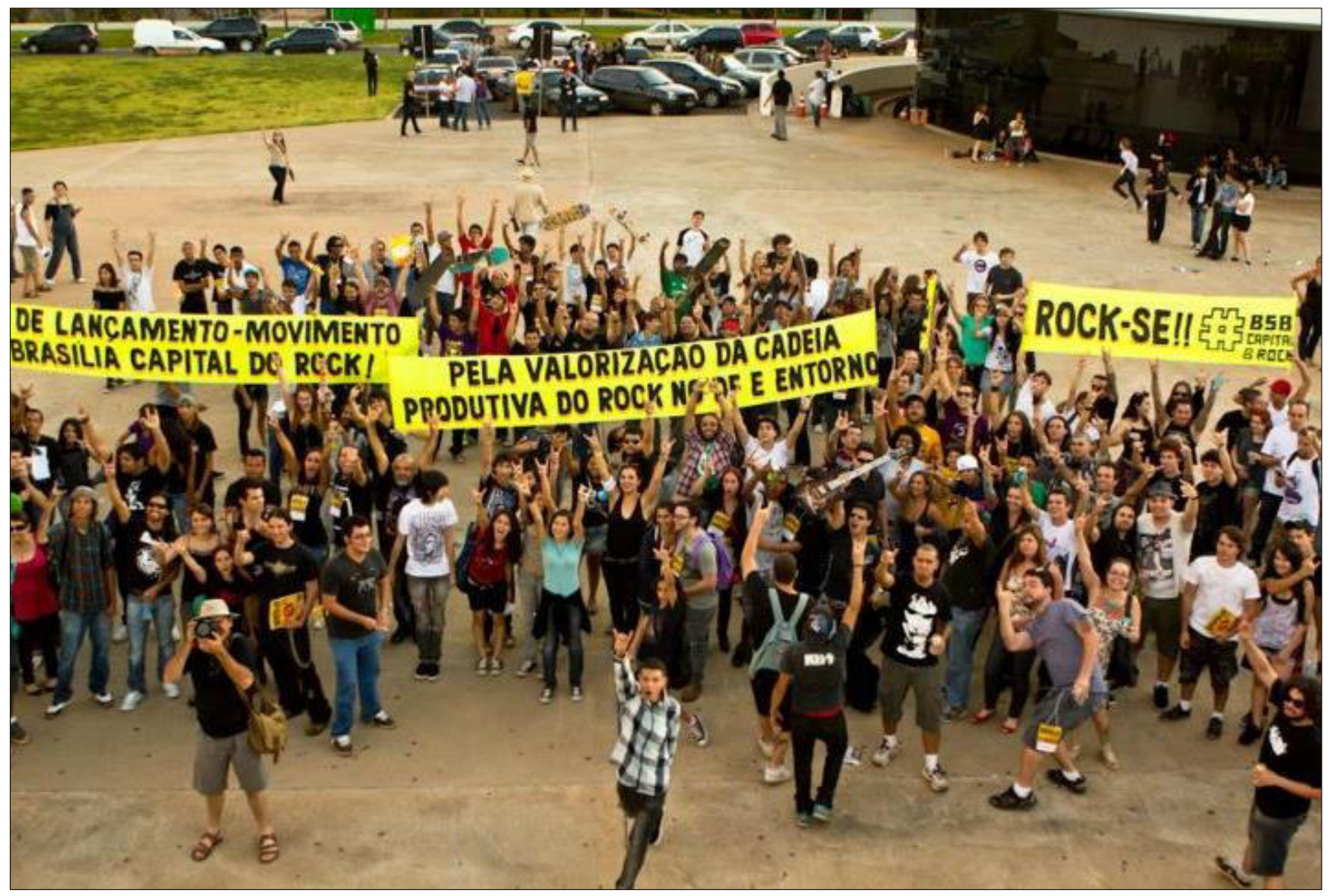

Figura 09: Lançamento do Movimento Brasília Capital do Rock (2012)

Foto: Autor desconhecido 
O conceito de mobilização social, diferente do de manifestação compreende melhor os propósitos de projetos como o Cabeças e de movimentos como Brasília Capital do Rock. Toro (1996) alerta que:

\begin{abstract}
A mobilização social é muitas vezes confundida com manifestações públicas, com a presença das pessoas em uma praça, passeata, concentração. Mas isso não caracteriza uma mobilização. A mobilização ocorre quando um grupo de pessoas, uma comunidade ou uma sociedade decide e age com um objetivo comum, buscando, quotidianamente, resultados decididos e desejados por todos (TORO, 1996, p. 05).
\end{abstract}

Por mais que seja convidada, é a pessoa quem decide mobilizar-se ou não. De acordo com Toro (1996), “convocar vontades significa convocar discursos, decisões e ações no sentido de um objetivo comum, para um ato de paixão, para uma escolha que 'contamina' todo o quotidiano" (TORO, 1996, p. 05, grifo do autor). André Noblat foi indagado quanto ao sentimento de ter adotado o rock de Brasília, de estar participando, agregando e agindo em favor do legado oitentista do rock brasiliense.

Eu acho que manter viva essa chama que começou nos anos 80 é uma responsabilidade muito grande e eu acho que muita gente a assume. As mil bandas de Brasília, boas ou ruins, conhecem a história, elas querem essa história, elas se sentem filhas dessa história. Essa gente que faz o rock na cidade - eu não sou filho da Brasília, mas minha banda é - se sente, a gente se sente herdeiro disso, com certa obrigação de manter o nível, tanto de qualidade cultural quanto de proteção desse legado lá fora. É engraçado. Quando a gente viaja pra tocar, as pessoas têm uma expectativa porque é uma banda de Brasília. Nós já percebemos isso em São Paulo, no Rio, em Belo Horizonte, em vários lugares. Isso é muito interessante. Ser de Brasília tem isso. É como chegar no exterior e dizer: eu sou do Brasil, ah, então você joga futebol bem. O que dói é que a gente entende que a cidade não o protege. Comparando com a minha terra natal, a mídia valoriza muito mais, Pernambuco, Recife conhece seus próprios artistas. Dá um pouco de inveja. 
A fala de André Noblat sobre o rock BSB 80 e esse movimento recente, o Brasília Capital do Rock, tornou oportuno um gancho entre os anos 80 e a atualidade no sentido de uma reflexão sobre práticas apropriadoras dos espaços criados/adaptados pelo/para o rock brasiliense, se elas podem ser associadas ao desenvolvimento de práticas culturais de natureza turística. Sobre esta questão Rodrigo Leitão observou que:

Hoje tudo está mais organizado, surgiram espaços ainda nos anos 80 que estão aí até hoje, como os Teatros Galpão e Galpãozinho que hoje compõe o Centro Cultural Renato Russo. Além disso, tem a Funarte, os teatros das escolas e o próprio Teatro Nacional que abrigam as bandas atuais. Hoje, o governo (GDF) já entende a prioridade cultural e até fomenta a produção por meio de leis de incentivo a cultura. Além disso, os artistas da música se organizaram em vários festivais de bandas que preenchem a nossa agenda cultural o ano todo, até trazendo um certo turismo roqueiro prá cá.

Há de se entender que, assim como o rock brasiliense é uma fração do rock, o rock BSB 80 é uma fração do rock brasiliense. Esta porção (rock BSB 80) coexiste com o rock brasiliense atual. Retomando o conceito de Geertz de que a cultura é uma teia de significados que o homem teceu, compreende-se que na evolução, no passar do tempo, novos significados são incorporados à cultura, sendo assim, as maneiras de se fazer rock brasiliense se transformam através dos dias. Segundo Park (1971) é pela comunicação que a tradição se transmite. Para este autor:

[...] toda forma de sociedade, enfim, excetuadas as mais passageiras, têm uma "história de vida" e uma tradição. É pela comunicação que esta tradição se transmite. É desta maneira que a continuidade dos empreendimentos comuns e das instituições sociais se mantém, não meramente de dia para dia, mas de geração a geração. Assim, a função da comunicação parece ser a de manter a unidade e a integridade do grupo social em suas duas dimensões - no espaço e no tempo (PARK, SAPIR, 1971, p. $60)$.

O funcionamento da comunicação tanto assegura a unidade e a integridade do grupo social, como permite que os seus objetivos comuns sejam alcançados. Toro (1996) chega a reconhecer a mobilização social como um "ato de comunicação". Para o autor "mobilizar é convocar vontades para atuar na busca de um propósito comum, sob uma interpretação e um sentido também compartilhados" (TORO, 1996, p. 05, grifo do autor). 
A interpretação é essencial ao processo de comunicação. Segundo Park (1971), “o processo só se pode dizer completo, do momento em que resulta em alguma espécie de compreensão", o que quer dizer que a comunicação não segue a lógica ação-reação, ela é “expressão, interpretação e resposta" (PARK, SAPIR, 1971, p. 64).

Os processos comunicacionais se dão nas relações sociais. Estão ligados, neste caso, à produção e compreensão de significados, o que ocorre continuamente, já que o homem não escolhe tudo o que absorve. Este ciclo é completado quando tal conteúdo é partilhado. O todo sofre modificações, mas sua essência segue inalterada. Isto vale para os mais variados tipos de expressão, de gesto. Como foi visto, a comunicação parece agir em favor da unidade e das tradições dos grupos sociais, fazendo com que sobrevivam ao tempo.

Os entrevistados refletiram sobre a relação entre o rock brasiliense atual e o rock BSB 80. Foram questionados se hoje está mais voltado para o surgimento de novos artistas e bandas ou para uma contínua reprodução dos anos 80. Paulo Mattos esclareceu:

Hoje a coisa é totalmente diferente, porque na nossa época era completamente ideológico. Você tinha que fazer tudo. Para estourar uma banda como estouramos nós mesmos colávamos os cartazes nos pontos de ônibus, a gente fazia o silk screen do cartaz, a arte do cartaz, a gente fazia tudo. Se não fosse a gente fazer tudo não acontecia porque não existia apoio de ninguém, de nada. Não havia verba pública para cultura. Não existia estrutura. Então realmente era na cara e na coragem.

Hoje não. Hoje você tem estrutura. Tem recurso público destinado à cultura em que você pode ser contemplado ou pleitear. Ou seja, é muito mais fácil. Hoje você consegue até viver de música. O bom disso é você não precisar estourar para desenvolver um trabalho. Tem como fazer projetos com cultura, ação social. Ou seja, vários espaços que não existiam para trabalhar. 
Em relação ao mercado é muito mais dominado por que quando havia essa coisa de qualquer um que quisesse tinha que fazer. O espaço estava lá para ser ocupado por que a mídia não estava lá. A Brasília era um pouco excluída da mídia. É difícil, por exemplo, valorizar novos trabalhos autorais. É muito mais fácil uma reinterpretação de uma música que já existe.

Então naquela época o espaço era maior para trabalhos autorais porque era um espaço virgem. Hoje não. Hoje é um espaço cheio de iniciativas onde se tem que concorrer com um monte de coisas, várias com apelo comercial muito maior. Então fica difícil desenvolver um trabalho que fuja do direcionamento da grande mídia. Isso é o que eu acho ruim hoje.

Sobre esta mesma questão André Noblat afirmou que:

Do ponto de vista artístico é novo. O som é novo. É tudo rock. Fazemos rock como nos anos 80 com algumas diferenças. Nós temos uma geração que vive menos os conflitos sociais que existiam na década de 80. Era época da ditadura, saindo da ditadura. O rock dos anos 80 surge nesse período de transição para a democracia, ainda com censura, ainda com dificuldades de expressão. Essa geração que vive com mais facilidades, principalmente sociais e políticas. A gente observa, no conteúdo, não futilidade nem pobreza, mas não é tão contestador, não é tão genial o sentido das letras. Tem coisas geniais, mas é uma geração, com exceções, que peca muito no conteúdo. Mesmo no mundo de hoje há muita coisa para se falar e denunciar. $O$ rock vem perdendo um pouco da contestação. Estou generalizando, mas tem exceções. No contexto musical, construção melódica, instrumental é uma coisa mais moderna, obviamente. Se você observar, historicamente o rock no Brasil é influenciado pelo que vem de fora. Rock é uma linguagem universal. Começou na Inglaterra e nos Estados Unidos, mas virou uma coisa universal, você tem bandas da Suécia, da Austrália, da Inglaterra, dos Estados Unidos, da África, que tocam rock. Desde a década de 80, os filhos dos embaixadores que tinham acesso aos vinis e passaram a ser influenciados por aquilo. Não é diferente hoje, só que hoje a gente tem acesso a tudo muito mais rápido. Então, o rock nacional atualmente é influenciado pelo som de fora e daqui também, pela música do momento e isso é natural em todos os estilos. 
Ao ser questionado se as manifestações, os eventos, os espaços utilizados e demais atrativos voltados para o rock podem servir de fomento ao turismo cultural Rodrigo Leitão fez novamente um paralelo entre a década de 80 e os dias de hoje:

O rock brasiliense evolui. Não se baseia apenas num resgate dos anos 80. Como atração turística, o atual rock local não chama a atenção do país, mas as festas e os festivais sim. $O$ que se deve fazer para atrair público de outros estados é remover eventos com foco nacional. Não temos mais aquelas bandas que chamavam atenção da mídia nacional. Mas temos um forte apelo de ter sido a cidade que produziu artistas como Legião Urbana, Capital Inicial, Plebe Rude, Banda 69, Finis Africae, Arte no Escuro, Detrito Federal, entre outras. E por causa disso, bandas como Raimundos e Móveis Coloniais de Acaju estão tendo portas abertas. Esses são os âncoras para agregar novo público. Mas o Estado deveria equipar o roteiro turístico com um "mapa do rock Brasília", um circuito que seria oferecido aos turistas de forma genérica, como em outras cidades onde houve roqueiros famosos, que são os casos de Menphis (Elvis), Liverpool (Beatles) $e$ Dublin (U2), que tem roteiros nesse sentido.

Rodrigo Leitão atribuiu ao poder público a responsabilidade de se desenvolver estratégias turísticas como um "Mapa/Circuito do Rock Brasília”. Compreende-se, contudo, que o desenvolvimento do turismo não se resume à ação do Estado, nem à soma deste a empreendimentos privados. O turismo também envolve questões subjetivas de caráter social, econômico, ambiental e estrutural. Segundo Gastal e Moesch (2007) o Estado não se posiciona em favor da participação dos cidadãos nas decisões referentes ao direcionamento de investimentos. As autoras complementam este pensamento afirmando que:

[...] as diretrizes das políticas de turismo seriam ainda dependentes de decisões nas esferas do capital internacional, sob lógicas da globalização econômica, mas a implantação dos projetos que as concretizam, reproduzindo o domínio econômico, ocorrem nas localidades, afetando as pessoas e suas culturas. [...] Esse cenário indica a importância de o poder público local ser o elo articulador entre os agentes excluídos da concentração econômica, e de construir, de forma compartilhada, o projeto democrático e cidadão desejado pela comunidade (GASTAL, MOESCH, 2007, p. 41). 
Como proposta equiparada às do livro Cabeças - preservação da memória do grupo e da vida cultural de Brasília - Néio Lúcio propôs a criação de um museu afetivo da memória da cidade:

Pequenos depoimentos, vivências acontecidas, tanto em superquadras, lembranças incríveis, e todas elas nascidas de gente que está ali e é viva ainda na cidade. [...] o desdobramento era ir para o parque da cidade, por exemplo, arranjar com o governo um espaço, e aí sim construir uma área física que abrigaria algumas representações, imagens com fotografias incriveis que as pessoas estão digitalizando [...] as roupas, a moda da época, os automóveis da época, as imagens das quadras, da W3, das corridas de $1.000 \mathrm{~km}$ de Brasília, um espaço que reunisse todo aquele material, disciplinasse esse material como museu mesmo, que teria também restaurantes. [...] De repente, você quer fazer um encontro com seus amigos de infância. Vai nesse lugar, ali cheira a Brasília. Elas iriam fabricar e fazer esse museu e dar vida a esse espaço.

É Superturístico. Porque veja só. O Museu do Futebol, por exemplo, é um museu visitadíssimo. Ele é supersimples, mas ele é altamente bem boladinho, bem feito e tudo mais. [...] Brasília é uma cidade mundialmente conhecida, não só porque é capital do Brasil. Ela é mundialmente conhecida porque ela é nascida de um formato, de uma proposta de inovação. Era quando estavam surgindo os Beatles, que vieram depois inclusive. O movimento hippie, Brasília, tudo aí no mundo. Então eu acho que reunir essa gama enorme de material afetivo, esse mundo de imagem tirado das gavetas particulares das pessoas, de fotos com ângulos particulares, fotos de uma galera fazendo acampamento na beira do lago, [...] isso é um patrimônio fantástico. Você poder juntar tudo isso agora e poder jogar no espaço onde essas próprias pessoas vão poder estar lá dentro. Mas só que elas estão levando os filhos e os netos. [...] Se eu quero respirar a alma da cidade, eu vou nesse espaço. [...] Pode ter reproduções de ambientes, de eventos, não só os que aconteceram, mas também essas coisas contemporâneas, agregadas. Ou seja, não é um museu morto só, saudosista. São portas e janelas que te ligam a mundos e tempos diferentes.

Como foi destacado por Néio Lúcio, Brasília é uma cidade mundialmente conhecida. Visualmente as pessoas adentram a cidade sem nela tocar. Gastal (2005) afirma que isto se dá a partir do contato com imagens presentes no deslocamento: "por meio de fotos, cenas de filmes, páginas na internet, [...] cartões postais" (GASTAL, 2005, p. 13). 
Novos avanços tecnológicos ampliam tais possibilidades. Plataformas virtuais com imagens de satélite, por exemplo, permitem ao sujeito caminhar virtualmente pelas ruas de uma cidade. Este é o quadro do turismo de hoje. Apesar de ser ligado ao estranhamento, ao contato com o novo, vem perdendo o sentido do desbravamento:

[...] o desconhecido está menos ligado aos territórios - praticamente inexistem no planeta territórios ainda intocados pelos humanos - e mais associado a hábitos sociais ou a práticas culturais de grupos diferentes daquele do viajante (GASTAL, 2005, p. 59).

Segundo esta mesma autora, há presença de imaginários no deslocamento. Para ela "[...] as pessoas terão sentimentos, alimentados por amplas e diversificadas redes de informação, que as levarão a achar um local 'romântico', outro 'perigoso', outro 'bonito', outro “civilizado"”. Entende-se, neste ponto específico da relação entre turismo, imagens e imaginários proposta por Gastal, que o rock brasiliense, como prática cultural, tem a capacidade de transformar-se no desconhecido, por causa do seu jeito próprio de se inventar, pela organização do espaço do qual se apropria e pelos aspectos sociais que envolve. Como foi visto, o rock nacional se desenvolveu em outras cidades além de Brasília. Todas com suas peculiares formas. No entanto, o conceito "Brasília é a capital do rock" alcançou âmbito nacional e isto é um exemplo de como o rock brasiliense, sobretudo o de 80, age na produção da imagem e na construção do imaginário de Brasília.

Sobre o rock brasiliense e o turismo cultural, André Noblat se manifestou da seguinte maneira:

Eu acho que o rock tem um potencial enorme pra esse tipo de coisa. A gente tem o Porão do Rock, temos que fazer ele ser quatro vezes maior do que é. $O$ Porão do Rock se realiza no Estádio Nacional ou nas suas imediações. $O$ estádio é cercado de hotéis. $O$ turista que vem à Brasília ver um show, [...] um festival e tem todos os locais em volta, ele vai andando pro show. Brasília, a forma com que ela foi construída, é uma cidade que tem condições de receber grandes eventos, grandes feiras de música, grandes festivais, grandes shows. 
Mas saindo desses grandes eventos é uma cidade que tem um museu subutilizado, espaços culturais subutilizados, um Cine Brasília que mal tem uma programação decente. Lá tem o cinema, que tem um foyer que dá pra apresentar bandas, exposições. [...] A gente precisa ter um circuito em que as pessoas passeiem pela cidade e conheçam a história do rock. Mas não adianta ir num banco num prédio da Colina na UnB, onde eles sentavam. Nesse banco tem que ter alguma coisa. Essa história tem de ser contada: "nesse banco aqui sentou a galera do Capital Inicial e começou a fazer a música Fátima”, e lá teria um negócio tocando a música Fátima. É claro que tem de se criar atrativos para esses circuitos. No aeroporto, tem que ter lojas que vendam a cidade. Eu vejo isso em todos os aeroportos. O rock precisa estar no aeroporto, precisa estar na Feira da Torre. Precisa-se vender o rock da cidade como uma marca. [...] Vou lhe dar um exemplo prático: eu toquei agora no Texas, quando eu desembarquei no aeroporto, a primeira coisa que eu vi na esteira?! "uma guitarra gigante", porque eu estava chegando numa cidade que sedia um dos principais festivais de música do mundo. Quando eu comecei a andar pela cidade vi que toda ela estava enfeitada para o festival. O evento em si, era num pedaço da cidade, mas Austin sabia que naquele momento, independente de estarem no festival ou no outro lado da cidade estava acontecendo o South by Southwest que é um festival que enche todos os hotéis, restaurantes, lojas, bares, faz com que um monte de gente vá fazer turismo lá, gera uma puta duma renda, economia, imposto pro governo, mas o que eles fazem? Eles abraçam. [...] Na semana do Porão do Rock toda a mídia, tudo tem que ser mobilizado pelo estado para que se invista naquele processo. Você tem um puta de um projeto desse e não investe, aí não tem turista meu amigo. Não tem turista que venha. Por quê que eu vou pra Brasília, pro Porão do Rock? Eu sei lá o que é Porão do Rock. Tem que fazer campanha, tem que mostrar, trazer a mídia, fazer barulho, a cidade tem que se enfeitar, tem que abraçar, até para que se estimule outros a fazerem grandes eventos. 
André Noblat, produtor de um movimento atual, posterior à geração oitentista ${ }^{7}$, não se ateve a questões culturais, no sentido mais estrito do termo, trouxe aspectos do turismo num todo, inclusive, o seu caráter, corriqueiramente adotado, mercadológico.

Sabe-se que o turismo tem potencial econômico, que pode gerar renda para a cidade, que esta pode ser revestida, inclusive, em projetos culturais através de políticas de incentivo à cultura. No entanto:

Se quisermos, como muitos, que o turismo cultural se expanda, teremos que fazer muito mais do que simplesmente abrir casas históricas e novas atrações, na expectativa de que os visitantes chegarão e apreciarão sua experiência. [...] temos de prover os métodos de olhar, vivenciar e apreciar, reafirmando não apenas o sítio e os objetos, mas as oportunidades dos visitantes apreenderem novas formas de se relacionar com o lugar (GOODEY, 2002, p. 135).

Integrar o turista à vida da cidade, mesmo que temporariamente, parece ser um desígnio cultural do turismo. Como um processo que vai da desvirtualização de imagens préconcebidas à construção de imaginários, o que Gastal (2005) entende como materialização de sentimentos gerados a partir do contato com o novo, com o desconhecido.

Paulo Mattos fez as seguintes considerações sobre o turismo:

Eu acho que o turismo é muito ligado a tradição cultural de cada região. Existem os calendários de eventos tradicionais que são como vitrines da identidade cultural de cada local, de cada região. Esse tipo de evento tem um apelo turístico maior. Vias Sacras em alguns lugares, por exemplo, cada um com a sua característica. É muito importante trabalhar o turismo ligado à cultura porque assim o turista vai compreender muito mais a natureza, as características intrínsecas da forma de viver daquela população.

\footnotetext{
${ }^{7}$ No início da década de 80 André Noblat era recém-nascido, não participou do rock BSB 80.
} 
É perceptível a diferença de posicionamento nos dois últimos depoimentos. Paulo Mattos, participante ativo do rock BSB 80, demonstrou preocupação com o quê o turista irá absorver das tradições locais, da identidade cultural. Goodey (2002) partiu deste princípio ao se posicionar sobre as experiências vivenciadas e conhecimentos adquiridos na prática do turismo cultural:

Seu potencial educativo deve ter uma relevância direta para a vida no mundo de hoje. Depois que os visitantes se forem, deve-se perguntar se, como resultado da visita, eles passaram a compreender melhor as relações entre gente e lugar, como estruturas são construídas e sobrevivem, como artistas interpretam uma área e a vida em épocas passadas, como a dança e a música se desenvolvem em determinado lugar. O que queremos realizar é a integração do patrimônio cultural com a vida moderna, não apenas atingir uma meta de lazer, desvinculada da vida cotidiana do lugar (GOODEY, 2002, p. 137).

Goodey atentou ainda para incoerências entre a praticidade com que as coisas são realizadas hoje e o desenvolvimento de práticas turístico-culturais:

\begin{abstract}
A palavra de ordem de hoje é no sentido de que um maior número de pessoas viaje mais depressa, para um maior número de lugares; reunindo mais experiências, ainda que mais breves; recebendo mensagens curtas sobre o significado dos ambientes.

A única esperança do turismo cultural é que ele ofereça exatamente o contrário, em todos os níveis: menos gente, visitando menos lugares, mais devagar; reunindo menor número de experiências, com maior qualidade; recebendo mensagens mais detalhadas sobre o significado de lugares e manifestações (GOODEY, 2002, p. 136).
\end{abstract}

Acredita-se que o conceito e o desenvolvimento do turismo cultural não são similares nem proporcionalmente diferentes do turismo estritamente mercadológico. O conhecimento em turismo passa por um momento de desmitificação do que é cultural, se é apenas visitação e culto ao antigo ou se suporta novas abordagens como o fato de uma cidade recente como Brasília estar já transpirando suas próprias tradições. 


\section{CONSIDERAÇÕES}

Não faltam lugares no país que possibilitem o aprendizado em turismo cultural. O rock, Brasília e o recorte temporal anos 80 foram delimitações necessárias para poder-se, através de conceitos como o de topocepção, aprender a apreender a organização dos sujeitos no espaço na realização daquilo que admiramos e denominamos obras de arte. Apesar de cada lugar expressar singularidade nas formas de fazer, as práticas cotidianas são passíveis de identificação. O imaginário através desse espaço praticado é que sugere significados plurais, sugerem subjetividade.

Uma das maneiras próprias de se fazer rock BSB 80 era fazer sem ter com o quê fazer. Os recursos eram escassos, mas foi uma geração que aprendeu a improvisar. Os músicos se sobressaiam às dificuldades, faziam da rua palco, dividiam instrumentos e equipamentos. Felipe Seabra, da Plebe Rude, disse em certa ocasião: "na falta de música a gente montou banda". Hoje, este tipo de restrição não é realidade no meio musical. Atualmente, os músicos buscam espaço na mídia nacional e internacional, para tanto, divulgam seus trabalhos em páginas na internet, buscam apoio de patrocinadores, dentre outros meios. No entanto, o rock brasiliense atual, com todas estas facilidades, não tem a notoriedade que o rock BSB 80 atingiu e mantém.

Uma dificuldade deparada quando se entrevista artistas, músicos e produtores culturais é que eles recaem, demasiadamente, em questões políticas. Algumas vezes, foi necessária intervenção, por parte do entrevistador, tanto na argumentação, quanto através de questões previamente formuladas para conduzir a entrevista às questões voltadas ao objeto da pesquisa. Parecia inevitável falar sobre ineficiências do governo, corrupção, etc.

As teorias, os conceitos da comunicação mostraram-se pertinentes à discussão sobre turismo e cultura. Sendo assim, atentar às teorias da comunicação e suas nuances pode auxiliar futuros estudos do turismo e do imaginário urbano, sobretudo os que fazem referência às tradições locais e mobilizações sociais. 
$\mathrm{Na}$ literatura do turismo, o conceito de turismo cultural ainda é muito restrito à visitação do patrimônio físico/material. Percebe-se, entretanto, sinais de mudança deste quadro. Parece emergir, nas discussões de autores como Goodey, o reconhecimento do turismo cultural voltado às expressões locais, à participação e apreciação de ritos, à apreensão das formas de fazer.

Apesar de haver, em Brasília, apelo e potencial para roteiros, mapas e museus do rock, os eventos como shows, festivais, feiras e exposições demonstram ser uma realidade mais próxima e indicam, ainda, terem maior visibilidade e possível retorno financeiro.

Por fim, discutiu-se, a partir de textos, imagens e depoimentos de sujeitos participantes diretos do rock brasiliense, o turismo, a cultura, a comunicação frente às manifestações e mobilizações sociais de grupos, bandas, movimentos e projetos em Brasília na tentativa de entender como estes reagem socialmente ao/no tempo e ao/no espaço. O que se pode dizer, predizer ou especular, por ora, sobre o antigo e o novo, sobre cultura e turismo é que novas tecnologias continuarão gerando novos tipos de experiências, exprimindo um novo turismo, o que exigirá tato para se formular novas perguntas. 


\section{REFERÊNCIAS}

ALEXA.COM. Disponível em: http://www.alexa.com/topsites/countries;2/br. Acessado em 14 de Dezembro de 2014.

ANDRADE, José Vicente de. Turismo: fundamentos e dimensões. São Paulo: Ática, 1995.

BAUER, M. W.; GASKELL, George (Orgs.). Pesquisa qualitativa com texto, imagem e som. Petrópolis: Vozes, 2002.

BOM DIA DF. Rede Globo. Músico elege o Gilbertinho, no Lago Sul, como o seu lugar preferido em Brasília. Disponível em: <http://globotv.globo.com/rede-globo/bom-diadf/v/musico-elege-o-gilbertinho-no-lago-sul-como-o-seu-lugar-preferido-embrasilia/4105140/>. Acessado em 15 de Abril de 2015.

BRASIL. Ministério do Turismo. Secretaria Nacional de Políticas de Turismo. Departamento de Estruturação, Articulação e Ordenamento Turístico. Coordenação-Geral de Segmentação. Turismo cultural: orientações básicas. 3 ed. Brasília, 2010.

CERTEAU, Michel de. A invenção do cotidiano: 1. artes de fazer. Tradução Ephraim Ferreira Alves. Petrópolis, RJ: Vozes, 1994.

Os Fantasmas da cidade. In: CERTEAU, Michel de; GIARD, Luce; MAYOL, Pierre (Orgs.). A Invenção do Cotidiano: Morar, cozinhar. 5. ed. Petrópolis: Vozes, 2003.

DENZIN, Norman e LINCOLN, Yvonna S. Introdução: a disciplina e a prática da pesquisa qualitativa. In: DENZIN, Norman e LINCOLN, Yvonna: O planejamento da pesquisa qualitativa: teorias e abordagens. Trad. Sandra Regina Netz. Porto Alegre: Artmed, 2006.

ECO, Umberto. O nome da rosa. Trad. Aurora Fornoni Bernardini e Homero Ereitas de Andrade. Rio de Janeiro: Nova Fronteira, 1983.

FINIS AFRICAE. Página oficial da banda. Disponível em: $<$ https://www.facebook.com/bandafinisafricae?fref=ts $>$. Acessado em 21 de Novembro de 2014. 
GASTAL, Susana. Turismo, imagens e imaginários. São Paulo: Aleph, 2005.

GASTAL, Susana; MOESCH, Marutschka Martini. Turismo políticas públicas e cidadania. São Paulo: Aleph, 2007.

GEERTZ, Clifford. A interpretação das culturas. Rio de Janeiro, LTC, 1989.

Como elaborar projetos de pesquisa. 4. ed. São Paulo: Atlas, 2002.

GIL, Antônio Carlos. Métodos e técnicas de pesquisa social. São Paulo: Atlas, 1991.

GOODEY, Brian. Turismo cultural: novos viajantes, novas descobertas. In: Interpretar o patrimônio: um exercício do olhar. Belo Horizonte: Ed. UFMG, 2002.

GOOGLE TRADUTOR. Finis Africae tradução. Disponível em: $<$ https://translate.google.com.br/\#auto/pt/finis\%20africae>. Acessado em 12 de Setembro de 2014.

JOBIM E SOUZA, Solange. Imagem técnica e estética: Sobre os modos de produção da cultura e da subjetividade no mundo contemporâneo. In: Cine Imaginarium - Da arte de fazer psicologia, comunicação e cinema. Rio de Janeiro: Ed. PUC-Rio, 2008.

KOHLSDORF, Maria Elaine. A Apreensão da Forma da Cidade. Brasília: Editora Universidade de Brasília, 1996.

KOHLSDORF, Maria Elaine. A imagem topoceptiva do Setor Comercial Sul de Brasília. In: $7^{\circ}$ Encontro Nacional da ANPUR. Artigo técnico. Recife, 1997.

LETRAS.MUS.BR. Disponível em: http://letras.mus.br/. Acessado em 23 de Janeiro de 2015.

LIMA, Irlam Rocha. Escola de Escândalo, sucesso nos anos 1980, lança $1^{\circ}$ álbum em show. Correio Brasiliense. Dísponível em: $<$ http://www.correiobraziliense.com.br/app/noticia/diversao-earte/2013/06/01/interna_diversao_arte,369092/escola-de-escandalo-sucesso-nos-anos-1980lanca-1-album-em-show.shtml>. Acessado em 24 de Junho de 2014. 
Trinta anos de criação do grupo brasiliense Mel da Terra serão em

Outubro. Correio Braziliense, 2009. Disponível em: $<$ http://www.correiobraziliense.com.br/app/noticia/diversao-earte/2009/08/18/interna_diversao_arte,135759/trinta-anos-de-criacao-do-grupo-brasiliensemel-da-terra-serao-em-outubro.shtml>. Acessado em 12 de Outubro de 2014.

LÚCIO, Néio; GUERRA, Kito. Cabeças. Brasília: Cabeças-Centro Brasiliense de Arte e Cultura, 1989.

MAFFESOLI, Michel. Elogio da razão sensível. Petrópolis: Vozes, 2001.

O imaginário é uma realidade. Revista FAMECOS. Porto Alegre:

EDIPUCRS, $\mathrm{n}^{\circ} 15,2001$.

MINAYO, Maria C. de Souza (org.). Pesquisa social: teoria, método e criatividade. Petrópolis: Vozes, 2010.

MIXTO QUENTE. Canal Viva. GLOBOSAT. Legião Urbana invade o programa: ainda se apresentam outros grandes nomes do rock brasiliense, como a Plebe Rude. Disponível em: <http://canalviva.globo.com/programas/mixto-quente/materias/legiao-urbana-invade-oprograma.html >. Acessado em: 12 de Outubro de 2014.

MOLINA, Sergio \& Rodrigues, Sergio. Turismo metodologia e planejamento. Bauru: EDUSC, 2005.

MONTANARI, Valdir. História da música: da idade da pedra à idade do rock. São Paulo: Ática, 1988.

MOVIMENTO BRASÍLIA CAPITAL DO ROCK. Página oficial do movimento. Disponível em: <https://www.facebook.com/bsbcapitaldorock?fref=ts $\geq$. Acessado em 12 de Maio de 2014.

PARK, R. E.; SAPIR, E. Comunicação, linguagem e cultura. São Paulo: ECA-USP, 1971.

PARK, R.E. A cidade: sugestões para a investigação do comportamento humano no meio urbano. In: O Velho (org.). O fenômeno urbano. Rio de Janeiro: Zahar, 1979. 
PERRONE, Charles A. Letras e letras da música popular brasileira. Trad. José Luiz Paulo Machado. Rio de Janeiro: Elo, 1988.

POZENATO, Kenia Maria Menegotto; GIRON, Loraine Slomp; LEBRETON, Max. Interfaces: cultura, comunicação e turismo. Caxias do Sul: EDUCS, 2009.

SCHNEIDER, Wolf. De Babilônia a Brasília: A cidade como destino do homem, de Ur a utopia. Trad. Guttorm Hanssen. São Paulo: Boa Leitura, 1960.

TORO A., José Bernardo; WERNECK, Nísia Maria Duarte. Mobilização social: um modo de construir a democracia e a participação. Brasília: UNICEF- Brasil, 1996. 


\section{ANEXOS}

Anexo 01: Outros depoimentos - Néio Lúcio.

Anexo 02: Outros depoimentos - Paulo Mattos.

Anexo 03: Outros depoimentos - Rodrigo Leitão.

Anexo: 04: Outros depoimentos - André Noblat.

Anexo 05: Outras imagens. 
ANEXO 01 
Néio Lúcio, o Cabeças no Parque da Cidade:

Quando começou a crescer muito aquilo na 311, eu pensei: não vou seguir nessa onda, que essa onda vai ser uma onda conflitante com o que a gente está fazendo, vai ser conflitante com as pessoas, foge das características. Aí acabamos na 311 e mudamos para o Parque da Cidade, onde chegamos naquela rampa acústica, hoje coberta por aquele Pavilhão de Exposição. O lugar era um nojo de sujeira, de cocô, de transeunte que passava lá, mendigo que dormia e o caramba a quatro. Eu olhei aquilo, nunca tinha tido uma atividade. Eu acho que a única atividade que tinha tido antes lá foi a inauguração, a missa ou coisa do gênero, e ficou abandonado aquele negócio lá. Fui com balde com meus alunos, que já não eram mais meus alunos do Cresça, mas meus amigos. Nós juntamos balde, vassoura, lavamos aquilo tudo. Não teve nenhum pedido de autorização, a gente não sabia nem de quem era aquilo. Era um absurdo aquilo ficar parado. Eu nem sei se tinha uma administração exatamente do parque nessa época. Era um negócio assim, essas coisas malucas de Brasília.

Limpamos tudo e então fizemos o Cabeças lá. Avisamos as pessoas: "Mudamos para um lugar lindo, maravilhoso, um parque". Porque agora a gente já tinha um público de 600 pessoas indo para dentro de uma quadra. Tá louco! Aí essas 600 pessoas foram para um lugar onde cabiam 2.500. Pareceu até que deu uma murchada, mas foi só o primeiro. Aí a gente tinha apresentações de 3.000 pessoas. Tinha lá o Renato Matos tocando com a Orquestra Sinfônica, que a gente produzia. Tocando "o telefone é muito pouco" com Orquestra Sinfônica e 3.000 pessoas na plateia. Aí tinha poetas como o Nicolas Behr, Toriba. No intervalo, enquanto a gente arrumava as coisas, eles faziam recitação de poemas, o Chacal, o Luís Martins.

Néio Lúcio, caso “carregando o piano":

A história daquilo lá é o seguinte: O piano estava reservado para ir para lá pela Fundação Cultural. E eu estou lá esperando, tudo acontecendo, e cadê? Já tá na hora do concerto começar e cadê o piano? Não tinha piano. Eu peguei o carro, fui lá na Fundação Cultural. Fechei meu carro, entrei na sala, peguei, sem autorização nenhuma, a chave da Kombi da fundação. Pedi a um grupo de capoeiristas que estava fazendo aula, botamos o piano de meia cauda da Vila Lobos dentro. Levamos para lá. Quando chegou lá, eu falei em público: me ajudem a levar o piano para lá, mas, por favor, não me abandonem, quando acabar o concerto me ajudem a devolver $o$ piano. E assim foi devolvido, e depois eu peguei o meu carro na fundação. Eu não era um funcionário autorizado a dirigir nem nada. Literalmente carregávamos o piano fazendo as coisas. 
Néio Lúcio, o Jogo de Cena:

Aí tinha o Jogo de Cena, que era uma ampliação do espirito da Feira de Música, que era oferecer para a cidade um espaço equipado com som de qualidade, para que então a arte pudesse ser exercitada. Aí nós ampliamos o Jogo de Cena para as outras linguagens, teatro, por exemplo. Como é que eu vou montar uma peça de teatro que tenha a duração de uma hora e meia, que tem figurino, que tem um cenário, a demanda é um trabalho danado, recursos financeiros, etc. E ainda tem que ter um público. Se fizer tudo isso e ainda não tiver ninguém para apresentar, não dá. Então, o que o Jogo de Cena pretendia e fazia? Ele era esse espaço, ele era esse equipamento, ele era essa possibilidade de você exercitar o seu trabalho artístico em um lugar para a criação de um público. Porque você era desconhecido na Feira de Música ou no Jogo de Cena, mas nem importava. Quando subia no palco, você estava com o teatro lotado. E no caso do teatro que eu estava falando antes, que é uma montagem longa, eu poderia simplesmente me inscrever, porque tem aquela cena do Shakespeare que é tão maravilhosa de ver que eu vou montar aquela cena, ou aquele monólogo. "Pô, eu vou me inscrever para fazer o monólogo na peça”. Quem é que poderia fazer monólogo de uma peça e anunciar numa cidade e ter a casa lotada para o seu monólogo? Em lugar nenhum. Se a motivação fosse o solo. Mas se você tem, oferece na cidade um equipamento, que na minha opinião era o governo que tinha que fazer, é obrigação do governo botar esses instrumentos disponíveis para o exercício das pessoas, aí você vai apresentar o seu monólogo de Shakespeare, para quinhentas e cinquenta pessoas ali. Se você for bom, aquilo te solta para o mercado. Se você não for bom, vai ser muito bom você ser médico sem uma frustração de nunca ter que subir em minha sala. Então, tinha essa função que era além da exibição artística só. Era uma coisa social, era uma coisa vivida. De uma cidade titânica e tudo isso aí. Então foram esses espíritos, eu diria assim, esses insights, esses norteamentos, noções, é que fizeram nascer o Cabeças dentro da cidade com a força que ele nasceu e com a história que até hoje se fala. Eu digo para as gerações de agora que é até mal contada, podia ser bem contada. 
Néio Lúcio, o concerto Grande Circular:

O Grande Circular foi inicialmente para a 312 Norte. Nos reunimos com a galera da 312 Norte, que inclusive frequentava o Cabeças, "Vamos fazer aí também, cara. Nós vamos fazer um lá e depois vocês dão sequência." Aí o João José Miguel, o Geraldinho Vieira, o Bascard hoje. Aí tinha lá o Beirão, tinha uma infinidade de pessoas, porque era uma cidade aquilo, a 312 Norte, e isolada.

Aí nós fizemos o Grande Circular lá e depois o Grande Circular no mês seguinte foi pro Cruzeiro, enquanto eles na 312 Norte geraram o Panelão da Arte, que nós éramos parceiros, irmãos, amigos, incentivadores e apoiadores. Ou seja, estavam multiplicando as ações dentro da superquadra. E lá no Cruzeiro, com o Robson, veio a Galeria Cruzeiro-Eixo e não sei o quê. E os concertos ficaram rolando no Cruzeiro. Nós fomos para o Guará, mas a galera de lá não deu sequência. Aí eu, depois outro projeto chamado Circuito Satélite.

Néio Lúcio, o Circuito Satélite:

O que era Circuito Satélite? Era um circuito que eu montava em todas as cidades satélites, palco, equipamento, aquela velha história: equipava, achava um local, montava a infra e criava alguma forma de doar isso para a galera poder exibir. Então fomos para o Paranoá, Gama, Cruzeiro, vários lugares. Sabe quem é que foi? A Legião Urbana. Estavam junto, apresentando para 100, 50 pessoas, o que rolava. Utilizavam-se desses recursos também. Eu estou contando isso porque ficou uma mística: o Renato nunca tocou no Cabeças. É uma bobajada. Não é bem assim, não. O Cabeças foi palco em várias situações e com vários nomes diferentes, o que permitiu o acesso. Muita gente transitou por lá: Cássia Eller, Zélia Duncan, Marco Pereira, todos passaram pelo Cabeças.

Ainda sobre o Renato, ele passou por várias fases. Com o Aborto Elétrico ele estava nessa fase punk, que era legal. Cabia, tinha a ver, mas é uma coisa também muito restrita. Era um público restrito e tudo o mais. Ele tinha ambições maiores, aí ele ampliou essa energia. Até brigou, umas coisas assim, mas ele bateu o pé naquilo que ele queria. Porque era ele que gerava as músicas. 
Néio Lúcio, a apropriação do espaço atualmente:

Hoje o mercado é diferente, tem uma série de exigências profissionais. Você acha que liberavam concerto, pagamento de ECAD, autorização de bombeiro, tinha que ter não sei quantos bombeiros. Para você ter uma ideia, uma vez eu tive uma briga com o administrador do parque. Ele chegou lá e disse: "Você tem que ter segurança". Eu falei: Como assim? Você está me obrigando a contratar segurança para vigiar quem? Nós? Que absurdo! Nós somos uma galera. Uma galera, não somos cinquenta galeras. Somos uma, vai cuidar da gente? Se eu botar uma polícia ali cuidando, é capaz até de eu ficar com medo de que isso gere um conflito [...].

Talvez estejam acontecendo muitos Cabeças por aí. Tem muitos grupos que eu vejo aparecendo aqui e outro lá [...]. Tinha aqui em São Sebastião os tais Radicais Livres, que faziam uns encontros, uns saraus. Pensei: são Cabeças. Isso é o espírito com outro nome de permissão, de ocupação. Lá no Gama, aqueles festivais de música, ou seja, tem muita coisa, no meu entender, que são Cabeças, porque têm essa pertinência.

Néio Lúcio, o Cabeças hoje:

Vira e mexe o Cabeças aparece, mas é mais pelo viés histórico de recuperação, do que de atividade propriamente dita. Atividades hoje o Cabeças não tem. Teve recentemente o Cabeças Brancas, que nós colocamos no Parque. Não foi exatamente um resgate. Foi um acontecimento, um evento, que oportunamente aconteceu naquela época e que não desencadeou e gerou consequências. Regularidades que eram matérias-primas do Cabeças. Toda e qualquer atividade que nós fazíamos eram normalmente plantadas para serem regulares, serem programas, para exatamente entrar numa cidade sem hábitos. Para construir hábitos saudáveis, legais, etc, numa cidade desacostumada ao hábito da novidade. Ela era uma cidade de novidades. Mas foi interrompida em 64 com o Golpe Militar, foi impedida do seu sonho. 
ANEXO 02 
Paulo Mattos sobre rock e turismo cultural em Brasília:

Então é muito legal trabalhar a cultura como um mote para atrair o turismo. Principalmente a cultura, que traz a identidade das regiões, permite fortalecer a cultura local, a identidade local e vai atrair recursos. Então eu penso que Brasília é muito especial nesse sentido por sua pluralidade. Temos gente de tudo quanto é lugar do mundo, todas as embaixadas, a formação cultural do candango, uma mistura do Brasil. Nós temos uma situação privilegiada em termos de acesso a informações, à cultura de outros povos. A gente miscigena isso de uma forma muito interessante, de uma forma antropofágica. Saem coisas muito novas daqui, tanto que Brasília virou realmente um espaço que produz muitos trabalhos culturais que estão conseguindo se estabelecer. Várias bandas e movimentos culturais daqui se afirmaram nacionalmente, o que não rolava naquela época, hoje já rola isso.

Paulo Mattos sobre o sentimento de ter vivido e participado do rock BSB 80:

É um barato! É legal pra caramba! A gente é considerada a primeira banda de rock pop da cidade que realmente fez sucesso. A gente teve a oportunidade de conhecer e acompanhar os agentes que construíram a identidade cultural da cidade. Por exemplo, Renato Russo com quem eu tive um convívio direto, antes mesmo de ele ter banda. Ele escreveu uma carta pra gente, dedicatória como fã. Então, assim, é super honroso! É uma lisonja a gente saber que ajudou a construir a identidade cultural da cidade, que a gente contribuiu e vem contribuindo. 
Paulo Mattos, mercado musical, Mel da Terra:

O que nós não temos é estrutura, comercial, de mídia. A mídia está em São Paulo e Rio. Dita muito o mercado. Lá tem mais recurso privado para a cultura. Brasília não tem tradição em patrocínio de cultura própria, local. A tradição aqui, infelizmente, ainda é de valorizar o que vem de fora. Os patrocinadores bancam mais uma atração de fora do que uma coisa produzida dentro da cidade. Às vezes é preciso sair daqui para ser reconhecido lá fora. Como foi feito com a Legião Urbana. Todas as bandas que estouraram tiveram que sair de Brasília para serem reconhecidas lá fora para depois ter público aqui. O Renato ficava puto por que não ia ninguém aos shows da Legião aqui, ninguém, antes deles estourarem. Eu fui num show deles e da Banda 69 na ABO que tinha só eu e a banda os assistindo e depois eles assistindo a 69. Também por que eles faziam mais uma cultura, um tipo de som que não tinha em Brasília ainda, tinha pouco. Depois foram surgindo casos específicos, como o Rolla Pedra, por que o Cabeças não era muito esse perfil, depois foi assimilando. Mas mesmo assim havia um pouquinho de rixa, por ser um movimento mais identificado com o hippie. No começo do movimento anarquista, muita gente achou que tinha que renegar o que vinha antes. Mas não tem nada haver, o anarquismo é muito mais aberto do que isso. Hoje tem muito mais haver a proposta do punk com o anarquismo mesmo, que assimila influências de outras coisas, mais aberto, menos preconceituoso. Os punks sempre tiveram letras de protesto, contra o conservadorismo. Então lá fora é ao contrário. Era mais aberto a aceitar a diferença. Mas aqui veio como um movimento utilizado pela grande mídia colonizadora, como eu falei, foi colocado de uma forma para as pessoas a parecer ser o que não era. Quando o pessoal realmente entender o que era o movimento punk anarquista no Brasil acabou com esse preconceito por que ele veio meio que pra brigar, por exemplo, com a MPB. As gravadoras multinacionais fizeram um pouco isso, colocavam num espaço de mercado os trabalhos do movimento punk e do rock em detrimento da MPB. Comercialmente funcionou assim e isso não foi legal. Mas hoje existe outra visão. As outras gerações, as outras bandas depois vieram reconhecendo o passado. Houve uma época em que era moda falar mal do Mel da Terra em jornal. Lá de cima a gente caiu pra debaixo da terra, era uma piada, engraçadíssimo. Depois passou. O Detrito Federal se lançou falando mal do Mel da Terra. Depois a gente ficou amigo, fez show junto, um ajudou a produzir o outro. Demorou para que as pessoas todas enxergassem que o legal é o respeito, a diferença, a diversidade. 
ANEXO 03 
Rodrigo Leitão sobre o sentimento de ter vivido e participado do rock BSB 80:

Fomos privilegiados pelo tempo histórico. Pegamos uma onda de expansão da cultura brasileira por meio da abertura política e de um plano econômico que proporcionou aos jovens o consumo do produto cultural que nós estávamos desenvolvendo, no caso aqui o rock. Produzir a partir de Brasília, com as informações que tínhamos em primeira mão, por causa do Corpo Diplomático e de músicos daqui que estavam vindo da Inglaterra e dos Estados Unidos, foi revolucionário para o momento que o Brasil vivia. Era uma euforia coletiva poder gritar o que estava engasgado na garganta do povo brasileiro por 25 anos de ditadura militar. E foi isso que ocorreu, estávamos entusiasmados com a liberdade, mesmo tendo enfrentado dois Estados de Emergência decretados pelo general Newton Cruz, com prisões e perseguições.

E mostramos ao Brasil o que os "filhos da revolução" sentiam. 
ANEXO 04 
André Noblat sobre o Movimento Brasília Capital do Rock e a apropriação do espaço:

Nós começamos a revitalizar o Teatro SESC Garagem para o rock. Este é um espaço histórico para o rock de Brasília. Muita gente começou por ali. A gente fez um projeto chamado Rock sem Fronteiras com vista à revitalização do teatro. Fizemos algumas ocupações no Museu da República que foram muito bem sucedidas. Criamos um projeto de capacitação com oficinas para profissionais como técnicos de som, técnico de áudio, produção. Fizemos um projeto voltado a contar a história do rock nas escolas junto ao Porão do Rock. [...] O que a gente tenta, no movimento, é abrir espaço para as bandas dentro de projetos como, por exemplo, o Cine Brasília Rock Club, que fizemos no início de 2014. Nós circulamos por várias cidades satélites com um caminhão-palco apresentando filmes ligados ao estilo e as bandas depois tocavam. Fizemos também o projeto Circula que criou oportunidades desde sessões fotográficas a shows para mais de cento e cinquenta bandas no DF. São projetos inclusivos, mas na prática eles não respondem a demanda do setor artístico por alguns motivos. Por mais que a gente tenha uma geração de bandas boas, umas vinte ou trinta bandas eu poderia citar, estão prontas ou quase prontas, teriam condições de fazer sucesso, por outro lado, existem novecentos e setenta que não, então as bandas precisam se aprimorar para poderem aproveitar os espaços. Então, o movimento estimula o pequeno produtor a criar seus festivais, a fazer seus projetos, a fazer ocupações. A gente teve o Guará Convida, que eram ocupações na praça; tem agora, também no Guará, sessões de pequenos shows em estúdio. O programa Esquina, na Rádio Cultura e o programa Porão do Rock na Rádio Transamérica são conquistas do movimento. Então a gente tem um espaço não só físico, tem espaço na mídia, na internet, tudo o que a gente pode fazer com o que a gente tem. Falta muito ainda. Mas falta principalmente uma consciência de que o rock pode representar riqueza pra cidade, como é o frevo, o axé e o samba, em Pernambuco, na Bahia e no Rio. Esse é o nosso principal debate. 
André Noblat sobre um logotipo do Brasília Capital do Rock:

A gente fez uma camisa com a estampa da escultura de Jucelino Kubichek do Memorial JK em que Jucelino acena os chifres (gesto que simboliza o rock/metal). Vendemos todas em dois segundos, no Porão do Rock.

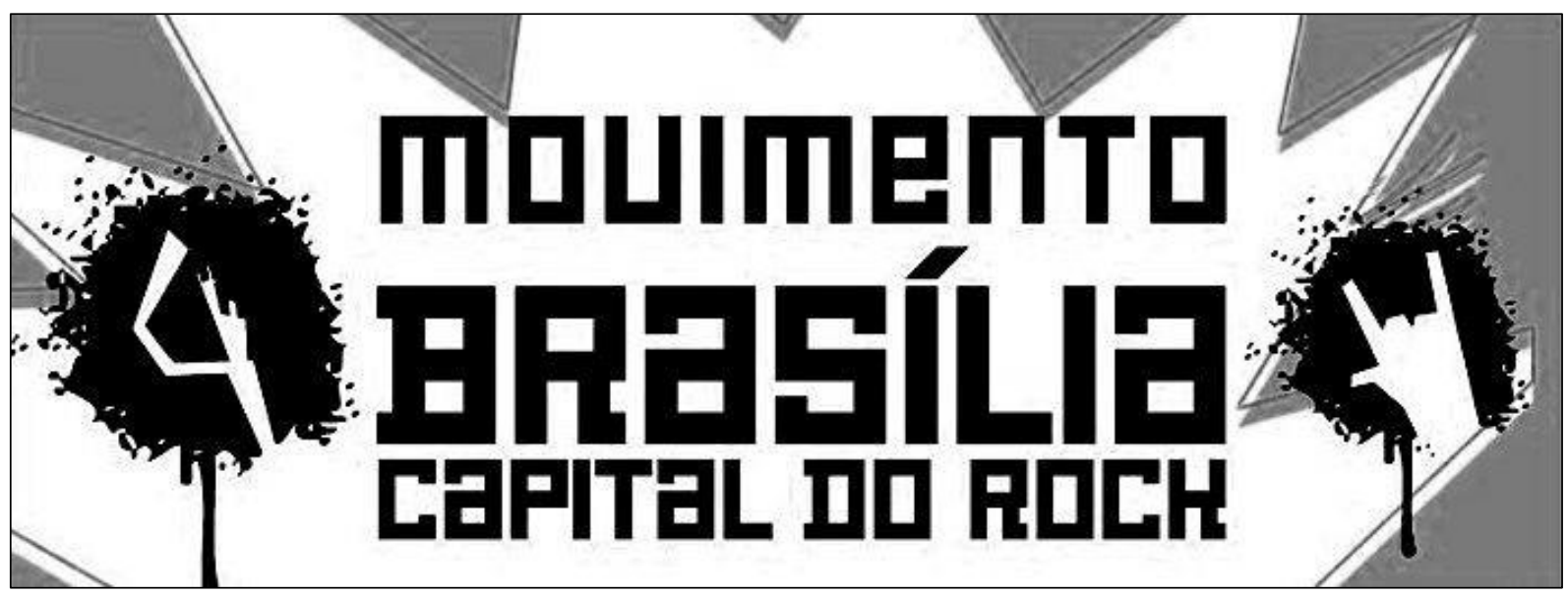

Arte do Movimento Brasília Capital do Rock

Autor: Thiago Palma 
André Noblat sobre o Brasília Capital do Rock e o quadro atual do rock brasiliense:

É um movimento de música que tem uma série de diretrizes: formação de público, geração de emprego e renda. É um movimento que tenta dialogar com o setor privado e com o setor público pra fortalecer o rock e a cultura da cidade tendo como objetivo final desse ciclo econômico. Porque o ciclo econômico acaba envolvendo o artista, o pessoal que monta palco, o pessoal que faz luz, técnicos, comércio, uma série de coisas. O movimento vem tentando encontrar eco no governo desde então. A gente teve muita dificuldade com o governo distrital passado, apesar de, no inicio do movimento, parecer querer investir. O movimento fez alguns projetos de formação de público que deram muito certo. O então governo fez com que projetos como o Porão do Rock não fosse apenas um show, mas que passasse, por exemplo, pelas escolas do DF. Mas foram ações pontuais. Você não consegue ter um projeto dessa dimensão se a cidade, se o governo não abraçar. Enquanto Brasília-governo não entender e não aproveitar criativamente vai perder essa riqueza. Nossa briga é para que a aproveite: pro músico é bom, pro produtor é bom, pro técnico de som é bom, pro cara que coloca palco é bom, pro cara que põe uma barraquinha e vai vender camisa é bom, pro turismo é bom, se você consegue criar, por exemplo, um circuito turístico que conta a história de Brasília e aí o turista não aqui só ver o congresso, ele vai ver aonde o Renato Russo, um memorial que mostre aonde começou o movimento rock da década de 80, com o Capital Inicial, depois a década de 90 que tinha uma efervescência, tinha o SESC Garagem, revitalizar isso pro rock, etc. É uma coisa que a gente tenta fazer, mas faz pontualmente. Não tem as condições que o estado teria pra fazer. Não é um investimento alto. É um investimento organizado, direcionado para o objetivo. Estamos abertos para o diálogo que já começamos com o governo atual. Achamos que existe uma abertura maior nesse sentido, pelo menos com as conversas que tivemos com os secretários de cultura e de turismo. Mas é um processo, não vai ser da noite para o dia.

O rock tem um problema, é dividido em muitos estilos. Eu sou a favor de sempre fazer shows que misturem todos esses estilos. Em geral se faz shows de nichos: hardcore, metal, rockabilly, e o roqueiro na prática, a maioria deles, no caso do metal, ele não odeia hardcore, só que ele escuta mais metal. Tem um problema assim no meio da cena do rock que é separar os estilos. Na minha opinião rock é rock. Você tem que tentar unificá-lo ao máximo possível. É claro que um cara do death metal não vai ouvir o rock do Nando Reis... mas aí tem uma divisão de no máximo duas praças. Tem esse problema de unidade, mas num todo é uma classe muito fiel ao rock e a cadeia produtiva musical de Brasília, independente de ser rock, se conhece, se une, o que ela precisa ter é um catalisador, algo que empurre isso. 
ANEXO 05 


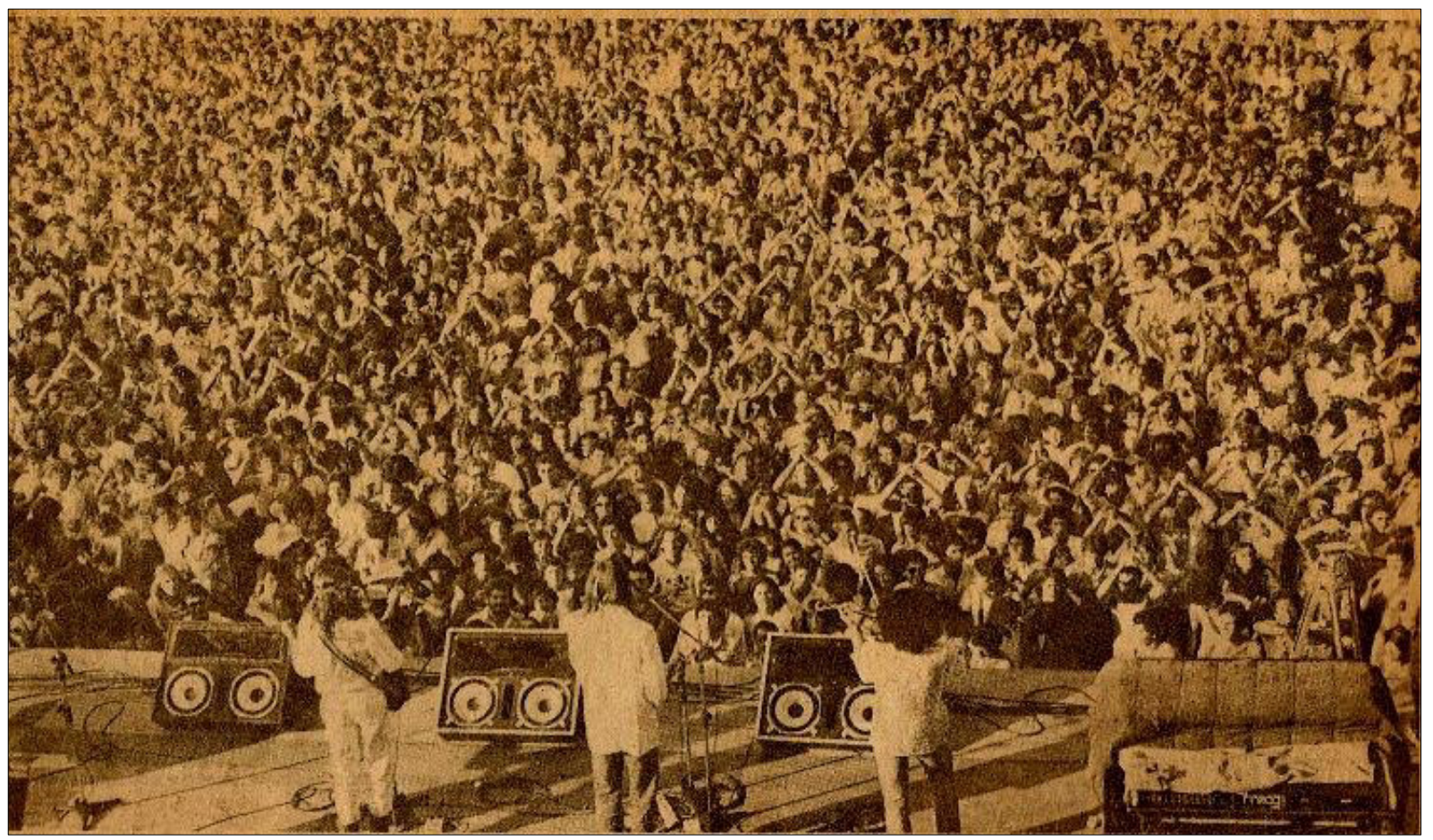

Rock Cerrado 1981

Foto: Autor desconhecido

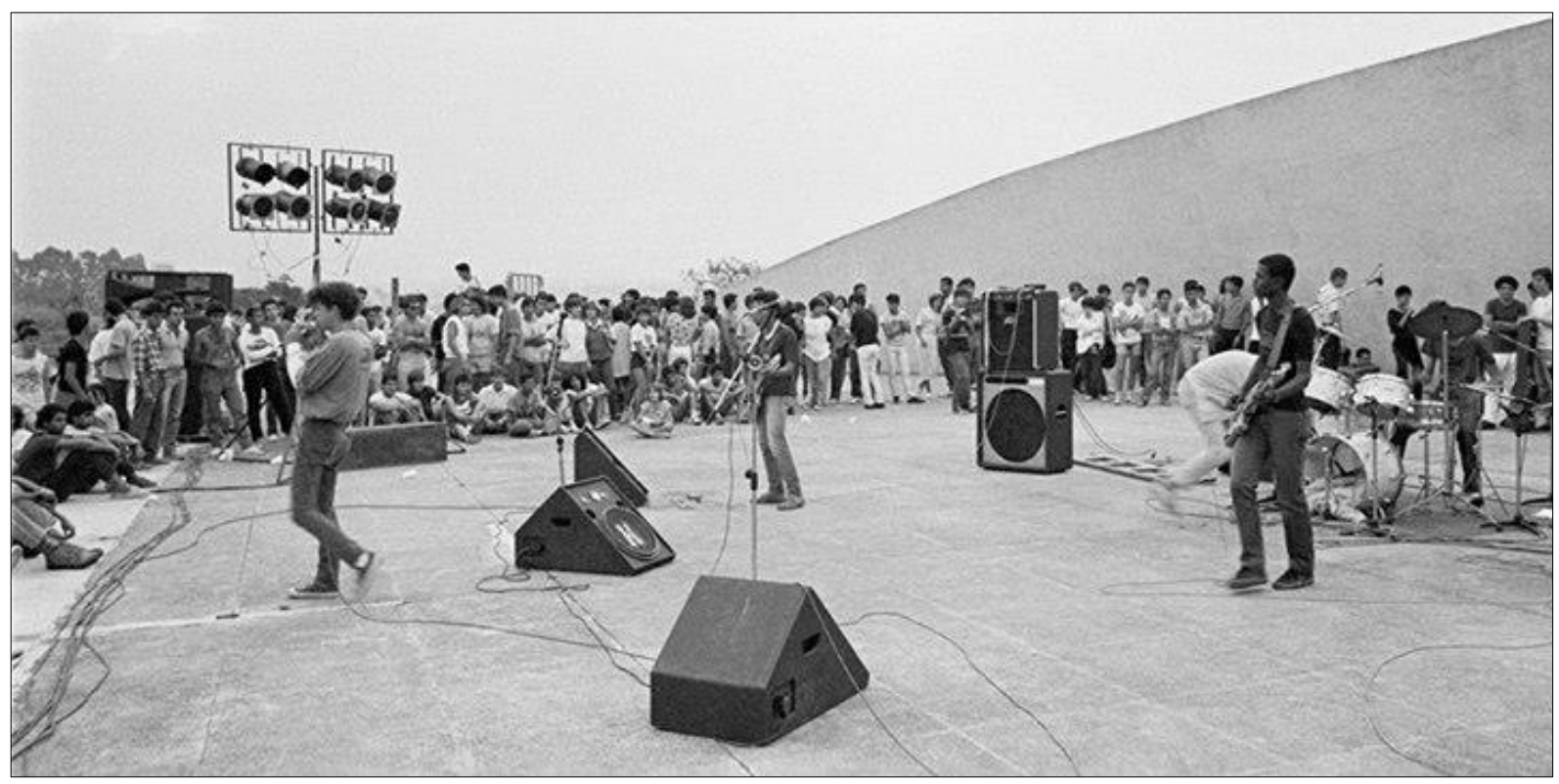

Elite Sofisticada na Concha Acústica (Setor de Clubes Esportivos Norte) Foto: Autor desconhecido 


\section{APÊNDICES}

Apêndice A: Roteiro de questões aplicado nas entrevistas. 
APÊNDICE A 


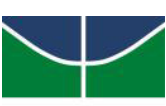

\title{
UnB
}

\author{
UNIVERSIDADE DE BRASÍLIA \\ CENTRO DE EXCELÊNCIA EM TURISMO \\ PROGRAMA DE MESTRADO PROFISSIONAL
}

ROTEIRO DE QUESTÕES

Não seria possível resumir uma década de ascensão de músicos e a história do rock BSB 80 numa única resposta. Mas o que você pode expressar sobre o sentimento de ter vivido aquela época em Brasília, presenciado e mesmo participado do rock BSB 80 ?

Assume-se, neste trabalho, que em Brasília a apropriação social do espaço ocorre primordialmente sob duas óticas: a da administração e a do cidadão. A apropriação do espaço pelo pelos cidadãos ocorre quando os indivíduos e comunidades têm condições de manifestar suas diferenças, o que possibilita a transformação do espaço para satisfazer e expandir necessidades e possibilidades da coletividade. Levando em conta os atos voltados ao rock, como se dava a apropriação do espaço nos anos 80 em Brasília?

E atualmente, como se dá?

São considerados atrativos do turismo cultural: obras de arte; espaços e instituições culturais (museus, casas de cultura); festas, festivais e celebrações locais; música, dança, teatro, cinema; eventos como exposições, feiras, shows e outras realizações artístico-culturais. Tendo ciência do que são esses atrativos questiona-se: Como as manifestações, os eventos, os espaços utilizados e demais atividades voltadas para o rock podem servir de fomento ao turismo cultural em Brasília?

Hoje, rock brasiliense está mais voltado para o surgimento de novos artistas e bandas ou para um contínuo resgate dos anos 80 ? Como se dão essas duas linhas de ação? 